\title{
Tank Farm Interim Surface Barrier Materials and Runoff Alternatives Study
}

\author{
D. L. Parker \\ Prepared by Columbia Energy \& Environmental Services, Inc. for \\ Washington River Protection Solutions \\ Richland, WA 99352 \\ U.S. Department of Energy Contract DE-AC27-08RV14800 \\ EDT/ECN: $\quad$ EDT-823178 UC \\ Cost Center: Charge Code: \\ B\&R Code: $\quad$ Total Pages: 80
}

Key Words: Interim Surface Barrier; barrier

Abstract: This report identifies candidate materials and concepts for interim surface barriers in the single-shell tank farms. An analysis of these materials for application to the TY tank farm is also provided.

TRADEMARK DISCLAIMER. Reference herein to any specific commercial product, process, or service by trade name, trademark, manufacturer, or otherwise, does not necessarily constitute or imply its endorsement, recommendation, or favoring by the United States Government or any agency thereof or its contractors or subcontractors.

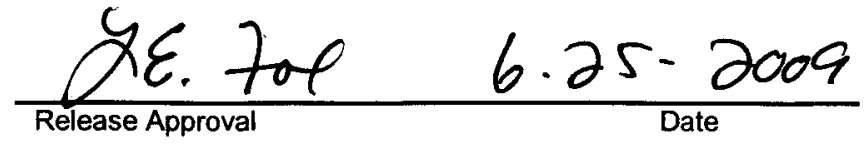

\section{Approved For Public Release}




\section{TABLE OF CONTENTS}

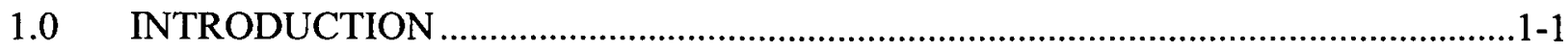

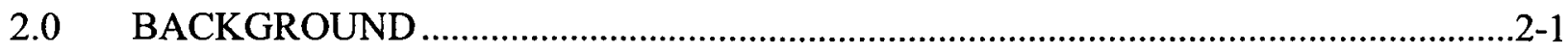

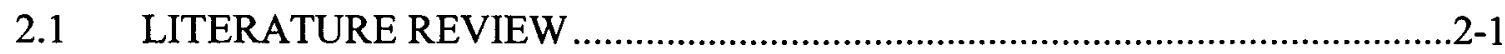

2.2 241-T TANK FARM INTERIM SURFACE BARRIER ……............................2-2

3.0 EVALUATION METHDOLOGY ………….........................................................

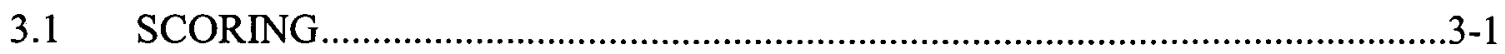

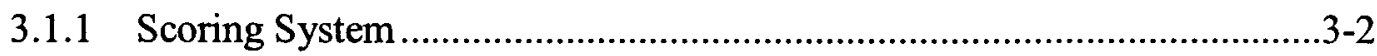

3.1.2 Scoring Criteria................................................................................

4.0 TANK FARM INTERIM SURFACE BARRIER ALTERNATIVES ............................4-1

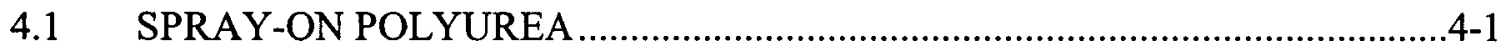

4.2 SPRAY-ON POLYUREA WITH GRAVEL ……........................................

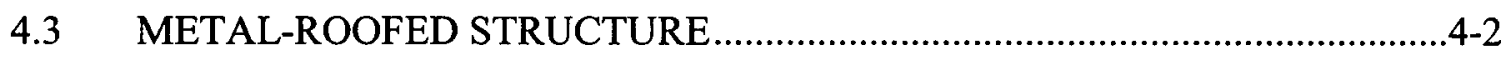

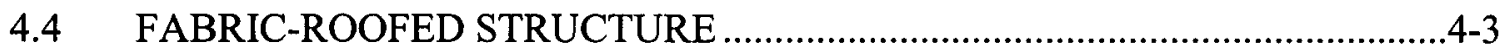

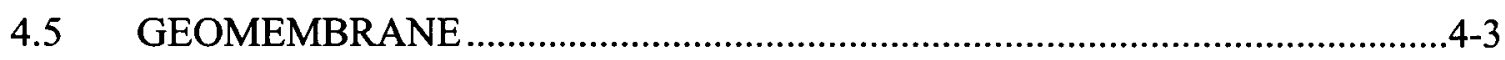

4.6 GEOMEMBRANE/GEOTEXTILE COMBINATION WITH GRAVEL ...........4-4

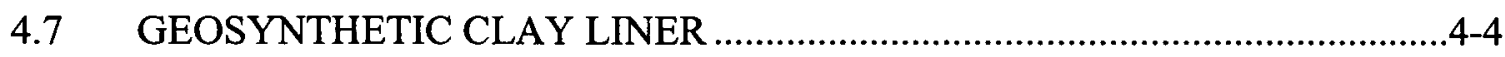

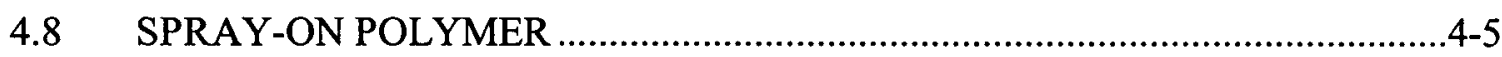

4.9 EVAPORATIVE BARRIER WITH SOIL ......................................................4-5

4.10 EVAPORATIVE BARRIER WITH GRAVEL .............................................4-6

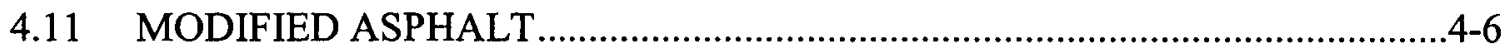

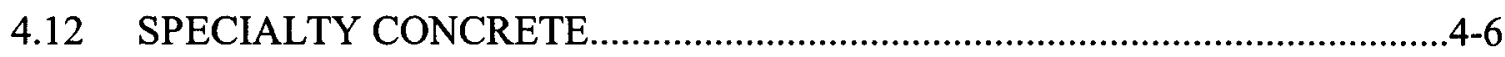

4.13 EVAPO-TRANSPIRATION BARRIER …….............................................

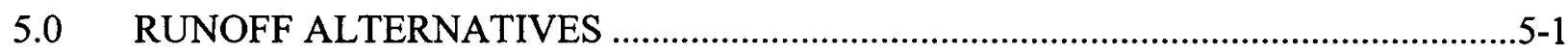

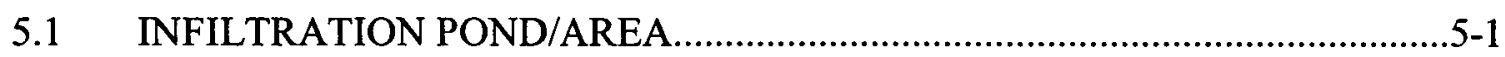

5.2 COLLECTION AND EVAPORATION POND …..........................................5-1

5.3 COLLECTION AND STORM WATER DISCHARGE SYSTEM.......................5-2

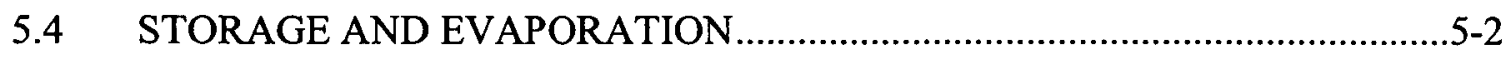

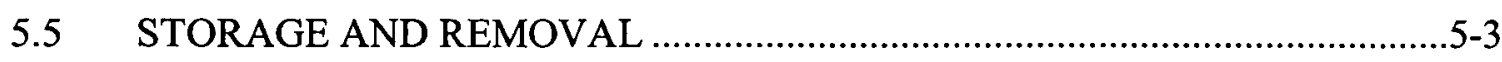

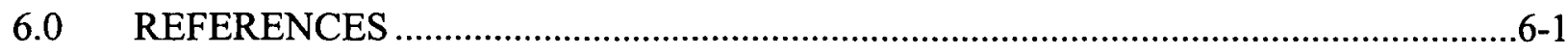

\section{LIST OF APPENDICES}

A TY Farm Interim surface barrier evaluation............................................................. A-i 
RPP-RPT-38323, Rev. 0

\section{LIST OF FIGURES}

2-1. 241-T Tank Farm Interim Surface Barrier ………………………………….................2-3

\section{LIST OF TABLES}

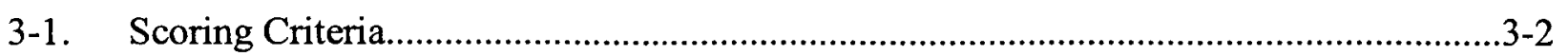


RPP-RPT-38323, Rev. 0

\section{LIST OF TERMS}

DOE

CH2M HILL

GPR

HDPE

HPT

IHT

MatCon $^{\mathrm{TM}}$

RCRA

SST

TOC

Wilder

WMA

WRPS
U.S. Department of Energy

CH2M HILL Hanford Group, Inc.

ground-penetrating radar

high-density polyethylene

health physics technicians

industrial hygiene technicians

Modified Asphalt Technology for Waste Containment

Resource Conservation and Recovery Act of 1976

single-shell tank

Tank Operations Contractor

Wilder Construction Company

waste management area

Washington River Protection Solutions LLC

${ }^{\mathrm{TM}}$ MatCon is a trademark of the Wilder Construction Company. 
RPP-RPT-38323, Rev. 0

This page intentionally left blank. 


\subsection{INTRODUCTION}

In fiscal year 2007-2008, the U. S. Department of Energy - Office of River Protection (DOEORP) and their contractor, CH2M HILL Hanford Group, Inc. (CH2M HILL), designed and installed an interim surface barrier in the 241- $\mathrm{T}$ tank farm. The barrier was constructed to minimize the infiltration of precipitation through soil containing contaminates from the 241-T106 tank leak. Water percolating through the vadose zone carries contaminants to the groundwater.

The $\mathrm{T}$ farm interim surface barrier (see Section 2.2) consists of a sloped polyurea surface barrier, storm water conveyance system, and infiltration pond located outside of the 241-T tank farm. The surface barrier sheds water away from the areas affected by previous tank leaks. The conveyance system collects and channels the water to the infiltration pond. The infiltration pond allows water to percolate into the ground away from contamination.

Washington River Protection Solutions LLC (WRPS), the DOE-ORP Tank Operations Contractor, currently plans to design and install additional interim surface barriers in the singleshell tank (SST) farms to mitigate the impacts of past tank leaks and spills until the tank farms are closed.

This study evaluates materials and concepts for interim surface barriers. The body of the report provides general information on materials of construction and their applicability for use in a tank farm environment. An evaluation of these interim surface barrier materials for use at the TY tank farm is provided in Appendix A. For the TY tank farm application, the modified asphalt barrier combined with an evaporative system for managing the runoff was selected from the alternatives considered. 


\subsection{BACKGROUND}

Two key sets of background information on interim surface barriers came from a literature review (Section 2.1) and from experience gained at the first interim surface barrier at Hanford tank farms, the T Farm Interim Surface Barrier (Section 2.2).

\subsection{LITERATURE REVIEW}

A number of interim surface barrier evaluations have been completed that identified and evaluated potential materials and configurations for application in the tank farms. In a 1988/1989 review of the SSTs at Hanford, the U.S. General Accounting Office recommended that the U.S. Department of Energy (DOE) "Develop specific plans to replace the gravel surfaces at the tank farms with a less permeable material and promptly replace the gravel surfaces if ongoing studies indicate that these surfaces could promote the movement of (leaked) waste toward the groundwater." The U.S. General Accounting Office report also expressed concerns about water pooling at surface low points during the onsite investigation.

Interim surface barriers were evaluated in 1992 as part of an effort to identify and evaluate alternatives to cover all 149 SSTs (WHC-SD-WM-ES-165, Single-Shell Tank Interim Cover Study). Four concepts were developed and evaluated for potential application. These included:

- $\quad$ Placement of a fine-textured top soil to absorb and retain precipitation for subsequent evaporation

- Above-grade roofed structures

- Low permeability surface materials

- Placement of low-permeability membrane liner below-grade materials to cause lateral migration.

A low permeability surface material, polymer modified asphalt, was identified as the preferred alternative due to low permeability and cost considerations. The engineering study concluded that implementation of these four approaches to cover all the SSTs ranged from $\$ 40$ million to $\$ 158$ million.

An innovative treatment remediation demonstration forum was held in Richland, Washington in May 1999 to discuss techniques for reducing and monitoring infiltration at the SST farms. The DOE, Hanford Site contractors, and various vendors from throughout the United States and Canada attended. Pacific Northwest National Laboratory summarized this conference in a twovolume report, "Reducing Water Infiltration Around Hanford Tanks" (Molton 1999). This effort is referred to as TECHCON 1999. Four technical sessions were conducted to discuss:

1. Moisture monitoring and characterization

2. Structures or buildings to cover the waste management areas (WMAs)

3. Surface modifications or covers

4. Near-surface modifications (barriers and permeability reduction techniques). 
The forum concluded that existing commercial capabilities could be employed to reduce and monitor infiltration in the WMAs, but that no one technology was appropriate for all seven WMAs (RPP-26157, Interim Surface Barriers).

The initiation of the RCRA Corrective Action program under Hanford Federal Facility Agreement and Consent Order, Milestone M-45-56-01, required an engineering study to assess the potential measures to limit infiltration through the vadose zone at the SST farms. The engineering report was completed in September 1999 and was updated in 2001 (RPP-5002, Engineering Report Single-Shell Tank Farms Interim Measures to Limit Filtration Through the Vadose Zone). The engineering report evaluated surface water run-on, surface water run-off, waterlines within the SST farms, and drywell monitoring caps for cracks. The Phase 1 RCRA Facility Investigation/Corrective Measures Study Work Plan for SST Waste Management Areas (DOE/RL-99-36) identified a number of general response actions, technology and process options associated with each general response action.

The evaluation of interim surface barriers was revisited in 2001 as a part of the RCRA Corrective Action Program (RPP-26157). This report summarizes previous long-term and interim barrier concepts. The report recommended that an engineering study be performed to determine the costs and impacts of placing a surface barrier. The report also recommends a demonstration of an interim surface barrier, thus providing information on actual construction costs, operations and maintenance costs, effectiveness, barrier life-span, and risk reduction.

The material selection process used to evaluate and select the interim surface barrier material used for the $\mathrm{T}$ farm interim surface barrier demonstration is documented in Section 9 of RPP-33431, Design Analysis for T-Farm Interim Surface Barrier (TISB). The report documents the evaluation, ranking, and scoring of seven interim barrier concepts/materials for application at the $\mathrm{T}$ farm. The polyurea material was selected as the preferred interim barrier material for 241$\mathrm{T}$ farm.

In 2007 the National Research Council published the Assessment of the Performance of Engineered Waste Containment Barriers (NAP 2007). While this report does not specifically address interim barrier applications, it does address the performance of barrier system components such as geomembranes, asphalt, and clay materials.

\section{$2.2 \quad 241-T$ TANK FARM INTERIM SURFACE BARRIER}

In fiscal year 2007-2008, CH2M HILL, designed and installed an interim surface barrier over the 241-T tank farm (Figure 2-1). The polyurea material selected for the $\mathrm{T}$ farm barrier was based on an evaluation of interim barrier options documented in RPP-33431, Section 9. The weighted ranking of the polyurea near-surface barrier material was the highest among the barrier materials/concepts evaluated for the $\mathrm{T}$ farm barrier application.

The existing $\mathrm{T}$ farm interim surface barrier consists of polyurea material sprayed onto a geotextile fabric to form a barrier used to collect precipitation, a lined trench to drain water, and an infiltration pond to dispose of the rainwater. The footprint of the barrier was built up using approximately 4,000 cubic yards of fill material to establish a 0.8-percent slope to gravity drain water to the infiltration pond. The infiltration pond was sized to accommodate approximately 60,000 gallons resulting from the 24-year, 24-hour storm event. The footprint of the barrier covers approximately 70,000 square feet. 
Figure 2-1. 241-T Tank Farm Interim Surface Barrier.

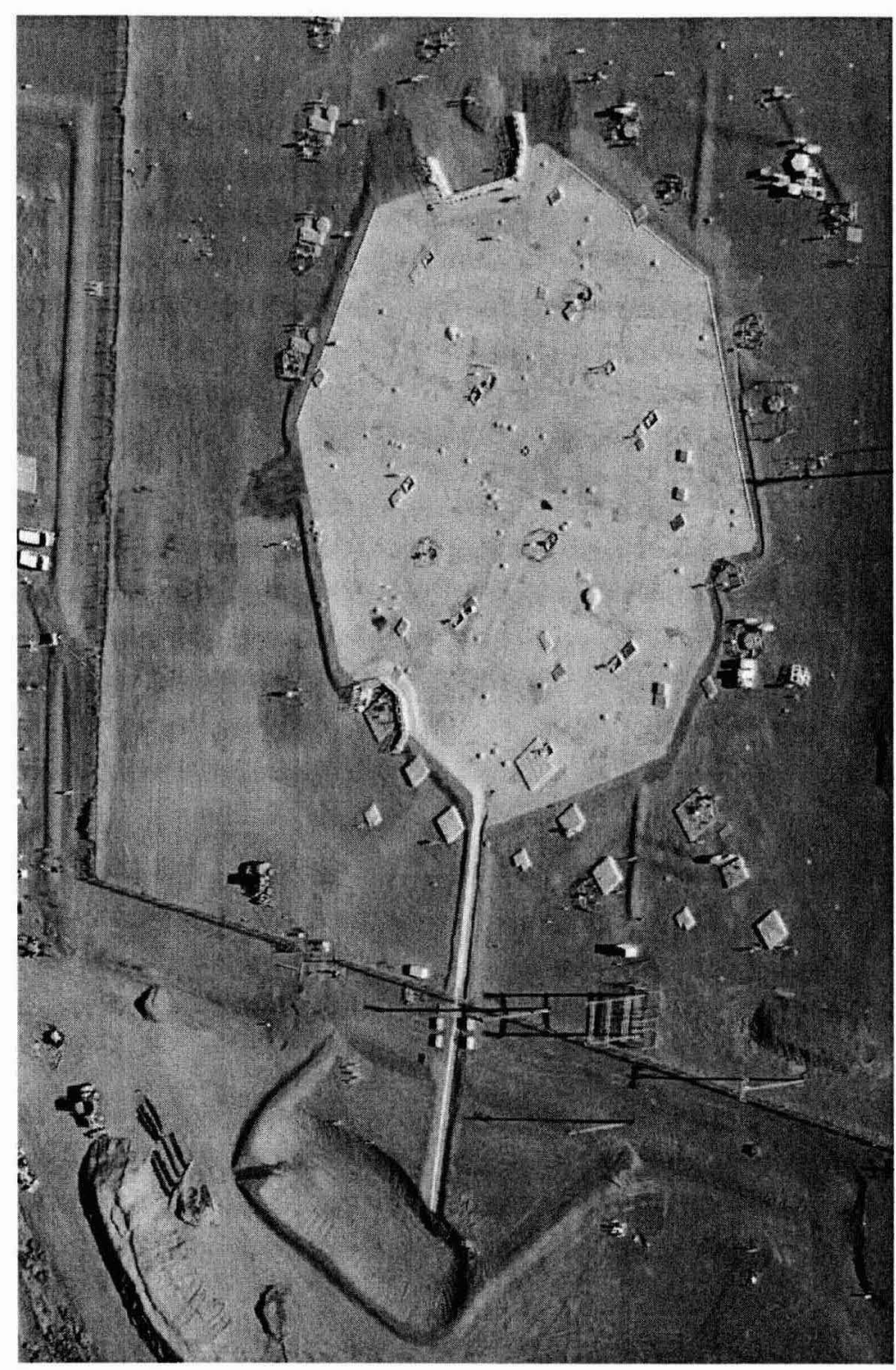

After completing the $\mathrm{T}$ farm interim surface barrier, CH2M HILL held a value engineering workshop to develop recommendations and a path forward for installing future tank farm surface barriers. The T-Farm Interim Barrier Construction and Monitoring Management Assessment Report (FY-2008-ENV-M-0143) presents the lessons learned and recommendations and makes the following recommendations:

- $\quad$ Simplify surface preparation. Establishing the 0.8 -percent slope in TY farm required approximately 4,000 cubic yards of fill material. Utilize the existing tank farm contours and only use enough fill material to limit the size and depth of puddles that would occur following a rain storm. Water would be disposed of by local evaporation and a perimeter trench. 
- Optimize liner. The polyurea material was sprayed to a minimum thickness of 0.25 inches. With an improved geotextile substrate, the thickness of the polyurea could be reduced by 50 percent. Consider using an improved polyurea product to minimize seam preparation. Additionally, a 6-inch layer of gravel over the polyurea barrier should be used to reduce thermal stresses, eliminate ultraviolet exposure, and eliminate the need for anchor trenches around the perimeter of the barrier.

- Temporary roof. Consider constructing a temporary roofed structure to cover specific areas for future interim barrier applications.

- Water disposal. Evaluate evaporating the water inside the farm and eliminate the infiltration area and lined trench. 


\subsection{EVALUATION METHDOLOGY}

This section provides a description of the general process that will be used to evaluate and select interim surface barrier materials/concepts for a specific application. The process will be modified as necessary to incorporate lessons learned. Application of this methodology to the TY tank farm is provided in Appendix A.

A number of materials/concepts for interim surface barriers are identified in Section 4 . The technical and performance requirements for the TY farm interim surface barrier are listed in RPP-SPEC-38937, TY Farm Interim Surface Barrier Subsystem Specification. These requirements include:

- $\quad$ Dome loading limits

- Designed for the environmental conditions present at the tank farms (i.e., wind, sun, temperature)

- Barrier monitoring

- $\quad$ Flexibility and expansion

- Cover the ground surface to minimize infiltration of precipitation

- Control barrier surface water runoff

- $\quad$ Minimum design life of 25 years with minimum maintenance

Several non-technical requirements for the interim surface barriers have been considered in this analysis. The non-technical requirements of concern include:

- Personnel safety

- $\quad$ Estimated cost for installing the barrier

- $\quad$ Estimated cost of maintaining the barrier over the design life

- Allow routine surveillance (personnel and vehicle access) to support tank farm operations

- $\quad$ Physically interface with existing tank farm features

- Decontamination/decommissioning

- Support future retrievals

- Availability of product information for the evaluation

- $\quad$ Existing tank farm requirements.

\subsection{SCORING}

The options are evaluated and ranked. The scoring system used provides the highest score to the best balance among the evaluation criteria. The scoring process estimates option performance in the following functional areas: 
- Cost

- Design

- Construction

- Operations

- $\quad$ Future Implications.

\subsubsection{Scoring System}

The scoring process assigns an importance or weighting factor between 1 and 3 to each criterion based on its relative importance (I). A score of 1 indicates less importance. A score of 3 indicates great importance (Table 3-1).

The scoring process also assigns a score between 0 and 10 to each material of construction based on its performance $(\mathrm{P})$ in each criterion. A score of 0 indicates the material does not satisfy the criteria. A score of 10 indicates it perfectly meets the objectives or criteria. A material receiving a score of 0 for any criteria disqualified itself from further consideration based on its inability to meet a minimum performance requirement.

Each material of construction received a score $(S)$ for each criteria equal to $\mathrm{I} * \mathrm{P}$. The sum of all scores (S) indicates the overall performance of the material.

Table 3-1. Scoring Criteria. (2 Sheets)

\begin{tabular}{|c|c|c|}
\hline $\begin{array}{c}\text { Functional } \\
\text { Area }\end{array}$ & Criteria & $\begin{array}{c}\text { Importance } \\
\text { (I) }\end{array}$ \\
\hline Cost & Installation and maintenance & 3 \\
\hline \multirow[t]{3}{*}{ Design } & Environmental conditions & 2 \\
\hline & Flexibility and expansion & 1 \\
\hline & Dome loading & 3 \\
\hline Construction & Safety issues during construction & 3 \\
\hline \multirow[t]{3}{*}{ Operations } & $\begin{array}{l}\text { Tank farm facility surveillance and } \\
\text { monitoring }\end{array}$ & 3 \\
\hline & Retrieval & 2 \\
\hline & Interim Barrier monitoring & 2 \\
\hline \multirow[t]{3}{*}{ Future Implications } & Decommissioning & 3 \\
\hline & Impacts on tank farm soil investigations & 2 \\
\hline & Applicability at other tank farms & 2 \\
\hline
\end{tabular}

\subsubsection{Scoring Criteria}

3.1.2.1 Cost Functions. The scoring process considers installation cost and operation and maintenance cost together. Installation and maintenance cost received an importance (I) score of 3. Performance (P) scores were assigned to the options considered, with the lowest cost option receiving the highest score and the highest cost option receiving the lowest score. Materials that have low costs for design and construction (relative to other materials) received a score of 10 . 
Known maintenance costs that include replacement or barrier components with limited design life are included in the cost estimate.

3.1.2.2 Design Functions. The requirements defined in Section 3 of RPP-SPEC-38937 were reviewed to identify potential evaluation criteria. Since a number of the requirements are necessary for all barrier types so will not be discriminators, many requirements are not used in the evaluation process. The scoring process considers three design criteria in which the barrier option differs: environmental conditions, expansion, and dome loading. For example, under the dome loading criteria one option may not add any additional material to the tank farm surface while another option may add soil to the tank farm surface that reduces the available dome load by one-half. While both of these options may meet the criteria, the option that does not add any weight to the tank farm surface provides greater operational flexibility and is favored over the option that reduces the available dome loading.

Environmental conditions deal with the ability of the barrier alternative to survive under the natural environment, natural phenomena hazards, and induced environmental requirements identified in the subsystem specification. An importance factor of 2 is assigned to environmental conditions.

Expansion addresses the ability of the barrier alternative to be expanded in the future if it is determined that the footprint of the barrier should be increased. An importance factor of 1 is assigned to the expansion.

Dome loading addresses the mass added to the tank farm that reduces the available dome loading margin. All interim barrier options would have to meet the dome loading requirements defined in RPP-SPEC-38937; however, dome loads associated with the weight of the interim barrier reduces the dome loading margin for future operational and waste retrieval actions. An importance factor of 3 is assigned to the dome loading criteria.

3.1.2.3 Construction Functions. The scoring process considers safety issues during construction. Each of the materials and options involve varying levels of construction personnel, equipment, and construction methods. The evaluation of safety issues during construction provides a means to differentiate potential industrial health and safety issues. The weighting factor applied to the safety issues during construction received and importance (I) score of 3 .

3.1.2.4 Operations Functions. The scoring process considers three operations criteria: tank farm facility surveillance and monitoring; retrieval; and interim barrier monitoring.

Ongoing operations involve performing routine surveillance and monitoring of existing tank monitoring systems, maintaining tank monitoring systems. Impacts to ongoing operations include the restrictions inherent to the material/option such as the need to establish dedicated drive lanes and vehicle routes or in the case of the overhead structures the limitations for deploying a crane. The weighting factor applied to the impacts to ongoing operations received an importance (I) score of 3 .

Retrieval received an importance (I) score of 2. The Hanford Federal Facility Agreement and Consent Order (Ecology et al. 1989) requires retrieval of SSTs and closure of the SST waste management unit. Therefore, materials of construction that preclude retrieval and closure (without barrier removal) received a performance $(\mathrm{P})$ score of 0 . Materials with little or no impact on retrieval and closure (relative to other materials) received a score of 10 . 
The scoring process considers the potential application of the materials/options at the other tank farms that are being considered for future application of an interim surface barrier. Applicability at other tank farms received an importance (I) score of 2.

Interim barrier monitoring addresses how well a particular interim barrier material or option lends itself to monitoring the barrier integrity following construction. The monitoring function received an importance (I) score of 2 .

3.1.2.5 Future Implications. The scoring process considers three operations criteria: decommissioning; impacts on tank farm soil investigations; and applicability at other tank farms.

Specification of closure criteria for the single-shell tanks and tank farms has yet to occur. Closure may require removal of the interim surface barrier. Therefore, any material of construction that cannot be credibly removed received a performance $(\mathrm{P})$ score of 0 . Easily removed materials (relative to other materials) received a score of 10 . This criterion received an importance (I) score of 3.

The scoring process considers the interim barriers impact on the ability to perform soil investigation in the tank farm at some future date if deemed necessary. Impacts on potential future tank farm soil investigations received an importance (I) score of 2. Materials and options that preclude or hinder subsurface investigations (i.e., drilling) in the tank farm are less favorable and have a lower performance score than materials/options that would not impact potential soil characterization activities.

Applicability at other tank farms addresses a given material/option utility at other tank farms that may have a larger footprint and/or involve more equipment and interferences. Materials/options that have specific size limitations or are not suited to accommodating varying levels of in-farm above-grade equipment receive a lower performance $(\mathrm{P})$ score compared to those materials/ options that are easily adapted to different footprints and conditions. This criterion received an importance (I) score of 2 . 


\subsection{TANK FARM INTERIM SURFACE BARRIER ALTERNATIVES}

Previous studies have evaluated potential surface barrier materials (see Section 2.2). This document enhances the existing knowledge by evaluating a broader set of barrier technologies and applying the lessons learned and recommendations from FY-2008-ENV-M-0143. Additionally, commercial vendors were contacted to collect current cost information and investigate advances in barrier materials.

The function of interim surface barriers is to limit the infiltration of precipitation into the ground beneath the barrier footprint to slow the migration of contaminants through the vadose zone. Planning and design of interim barriers will incorporate the lessons learned in FY-2008-ENV-M0143 to optimize the design and minimize cost. Potential surface barrier materials and concepts are described in Sections 4.1 through 4.13.

\subsection{SPRAY-ON POLYUREA}

A spray-on polyurea barrier consists of a nonwoven polypropylene geotextile fabric that has been sprayed with a polyurea layer of at least 125 mils thick. The surface of the tank farm will be prepared by grading the existing surface to remove the existing berm, re-grading the tank farm surface to fill in low spots and redistributing existing material in accordance with the cut/fill plan. Pipe sections and utility vaults will be installed around existing tank farm infrastructure, such as risers, drywells, and equipment installed on grade in order to provide access. Anchor trenches would be required around the perimeter and through the interior to prevent uplift from the wind (see Section A3.1.3). Fill material will be used to establish the final grade. Fill material will be stockpiled next to the tank farm fence line, conveyed over the fence, and hauled to the barrier area where it will be spread, compacted, and graded to establish the final grade.

A spray-on polyurea barrier would resemble the interim surface barrier installed over the 241-T tank farm. A detailed description of the spray-on polyurea material and application to the 241-TY tank farm is included in Appendix A. Table A-1 details the scoring results for spray-on polyurea option for 241-TY farm.

Advantages of using the spray-on polyurea option include:

- Utilized similar option in T farm

- Barrier can be monitored through visual inspection.

Disadvantages of using the spray-on polyurea option include:

- $\quad$ Spray-on polyurea option apparently attracts radon, resulting in operational issues

- Installation is labor intensive

- Subgrade preparation would be required. Subgrade preparation would require placement, compacting, and grading fill material to create a defined slope for drainage. 
Although a spray-on polyurea barrier was utilized in 241-T farm, the radon issues encountered have decreased the feasibility of this option. Experience has also shown the spray-on polyurea barrier becomes slick when snow or rain has fallen.

\subsection{SPRAY-ON POLYUREA WITH GRAVEL}

The spray-on polyurea barrier with gravel option resembles the polyurea barrier described in Section 4.1 with an additional layer of gravel (nominally 6 inches) placed on top of the polyurea. Placement of gravel on top of the polyurea would require geotextile and control on the backfill material to ensure that vehicle traffic does not compromise the barrier integrity. Table A-1 details the scoring results for spray-on polyurea with gravel option for 241-TY farm.

Advantages of using the spray-on polyurea with gravel option include:

- $\quad$ Reduced thermal stresses

- $\quad$ Eliminates exposure to ultraviolet light

- Promotes local evaporation

- Eliminates need for anchor trenches.

Disadvantages of using the spray-on polyurea with gravel option include:

- Decreases ability to monitor polyurea layer for defects

- Increases difficulty in conducting barrier repairs

- Increases dome loading relative to the polyurea barrier without gravel

- Subgrade preparation would be required. Subgrade preparation would require placement, compacting, and grading fill material to create a defined slope for drainage.

The impact of the attraction of radon daughter products with the addition of gravel on the sprayon polyurea is unknown. The addition of gravel increases dome loading concerns. The need to monitor and control vehicle traffic to preserve the polyurea liner also decreases the feasibility of this option.

\subsection{METAL-ROOFED STRUCTURE}

A metal-roofed structure over a tank farm would consist of a pre-engineered free span metal building made of pre-fabricated steel frames. A free span building is shown in Appendix A, Figure A-9. Table A-1 details the scoring results for the metal-roofed structure option for 241-TY farm.

Advantages of using the metal-roofed structure option include:

- $\quad$ Pre-engineered metal buildings are commercially available

- $\quad$ Structure length is unlimited

- A prepared Subgrade with drainage slope is not required

- Roof panels can be removed for crane access

- Roof height provides access for tank farm and retrieval equipment.

Disadvantages of using the metal-roofed structure option include:

- $\quad$ Free span widths of commercially-produced buildings are limited to 300 feet

- $\quad$ Building requires anchorage. 
Metal-roofed structures are generally used for permanent structures. This was the most costly option evaluated which limits feasibility for a large barrier.

\subsection{FABRIC-ROOFED STRUCTURE}

A fabric-covered roofed structure would consist of pre-fabricated steel arches covered with a flexible membrane cover. A fabric-roofed structure is shown in Appendix A, Figures A-10 and A-11. Table A-1 details the scoring results for the metal-roofed structure option for 241-TY farm.

Advantages of using the metal-roofed structure option include:

- $\quad$ Structure length is unlimited

- A prepared subgrade with a drainage slope is not required.

Disadvantages of using the fabric-roofed structure option include:

- $\quad$ Free span widths of commercially-produced buildings are limited to 250 feet

- $\quad$ Roof height could restrict tank farm and retrieval equipment

- Over a span of 250 feet, the interior height at the edge would be 18 feet

- Over a span of 250 feet, the interior height at the center would be 72 feet.

The fabric-roofed structure is also a costly option. The commonality of wind on the Hanford Site complicates the use of a fabric-roofed structure. The limited design life of the fabric-roofed structure further decreases the feasibility of this option.

\subsection{GEOMEMBRANE}

Geomembrane materials are impermeable to water and are a common industry application for containment of hazardous or municipal waste. For use as a surface barrier, the geomembrane would include an under liner of geotextile fabric for protection from the subgrade. The exposed geomembrane would have a textured surface and is a three layer composite: A light reflective top layer, an electronically conductive bottom layer, and a standard carbon black stabilized layer. The light reflective layer on the membrane reduces thermal expansion and minimizes radiant heat buildup. The electronically conductive layer allows the membrane to be spark tested for defects. Spark testing is an effective method of leak detection. Anchor trenches would be required around the perimeters and through the interior to minimize wind uplift (see Section A3.3.3).

Geomembranes come in a number of different polymers and thicknesses with a wide range of performance characteristics. A typical geomembrane installation is shown in Appendix A, Figure A-16. Table A-1 details the scoring results for the geomembrane option for 241-TY farm.

Advantages of using the geomembrane option include:

- $\quad$ Size is unlimited

- Widespread commercial use

- $\quad$ Suitable for covering large areas with minimal penetrations.

Disadvantages of using the geomembrane option include: 
- $\quad$ Riser extensions and access boxes would be necessary to maintain access to equipment and structure.

- $\quad$ Subgrade preparation would be required. Subgrade preparation would require placement, compacting, and grading fill material to create a defined slope for drainage.

- $\quad$ Penetrations in the geomembrane require specific details and are labor intensive.

The potential for the attraction of radon daughter products to the geomembrane is unknown. The geomembrane would need to be protected from weather and puncture is order to be feasible.

\subsection{GEOMEMBRANE/GEOTEXTILE COMBINATION WITH GRAVEL}

Geomembrane/geotextile combinations with gravel consist of the geomembrane liner with a layer of gravel over the liner. Table A-1 details the scoring results for the geomembrane/ geotextile combination with gravel option for 241-TY farm.

Advantages of using the geomembrane/geotextile combination with gravel option include:

- $\quad$ Reduced thermal stresses

- $\quad$ Eliminates exposure to ultraviolet light

- Eliminates need for anchor trenches

- $\quad$ Size is unlimited

- $\quad$ Promotes local evaporation.

Disadvantages of using the geomembrane/geotextile combination with gravel option include:

- Subgrade preparation would be required. Subgrade preparation would require placement, compacting, and grading fill material to create a defined slope for drainage.

- Compacting and grading of fill material would be require to create minimum slope

- Riser extensions and access boxes would be necessary to maintain access to farm structures and equipment

- A geotextile layer is required on top of the geomembrane to ensure vehicle traffic does not compromise barrier

- Increases dome loading relative to the geomembrane option.

The addition of gravel would be necessary for protection of the geomembrane/geotextile material. The increased dome loading concerns with the addition of gravel outweigh the cost benefit realized with this option.

\subsection{GEOSYNTHETIC CLAY LINER}

Geosynthetic clay liners have been widely used in liner and cap designs due to their low permeability. The geosynthetic clay interim barrier would consist of geotextile outer layers with a core of low-permeability sodium bentonite clay. The sodium bentonite clay is a naturally occurring clay mineral that swells when it is hydrated. When hydrated under confinement, the bentonite swells to form a low permeability clay layer with a hydraulic conductivity value of $5 \times 10^{-9} \mathrm{~cm} / \mathrm{sec}$ which is an equivalent hydraulic protection of several feet of compacted clay (GSE BentoLiner ${ }^{\circledR}$ application sheet). 
Installation consists of placing the geosynthetic liner on the ground (at-grade), laying down a layer of granular bentonite, placing a geomembrane on top, and welding the liner and membrane together. Finally, a layer of hydrated backfill goes over the top

Geosynthetic clay liners have been excluded from this analysis. The primary performance concerns with geosynthetic clay liners over the long term are desiccation, freezing, chemical incompatibility, and strength degradation (NAP 2007). The geosynthetic clay liner material is not considered suited to interim surface barrier applications at the tank farms because the moisture content of the clay material must be maintained or the material will dry out leaving cracks for water to pass through.

\subsection{SPRAY-ON POLYMER}

A number of commercial polymer products have been developed for use in soil stabilization and dust control. The existing gravel surface of the tank farms would not be suitable for direct application of these products because they require the presence of fine soil particles. A polymer barrier would consist of a layer of fines coated with polymer.

Spray-on polymers have been excluded from this analysis. Spray-on polymers require regular inspection and reapplication of the polymer at regular intervals, roughly one to two years, to ensure continued effectiveness. The minimum design life required of the interim surface barrier is 25 years with minimal maintenance. The spray-on polymers evaluated are not considered suitable to interim surface barrier application in the tank farms because they have limited operational life requiring frequent reapplication.

\subsection{EVAPORATIVE BARRIER WITH SOIL}

An evaporative barrier uses localized storage of precipitation and evaporation to minimize infiltration of water into the tank farm subsurface. It relies on the favorable evaporative conditions of the local climate.

The Hanford Site receives approximately 6 inches of precipitation per year, but evaporates approximately 47 inches $^{1}$. Testing on the Hanford Site has shown that a 3.3 foot thick silt-loam soil cover stopped drainage under ambient precipitation conditions with or without plants present ("Multiple-Year Water Balance of Soil Covers in a Semiarid Setting" [Fayer and Gee 2006]). Twenty four inches of soil (i.e., McGee Ranch silt) have an estimated water storage capacity of approximately 7.4 inches, equal to or greater than the annual rate of precipitation on the Hanford Site (WHC-SD-WM-ES-165).

Evaporative barriers have been excluded from this analysis. The amount of soil necessary to establish an evaporative barrier would be a dome loading concern. For the TY tank farm; the addition of 3.3 feet of soil approaches the allowable soil height for dome loading defined in RPP-SPEC-38937. Evaporative barriers would require limitations to personnel and vehicle access during the winter/spring when the barrier is storing water. Additionally, collection/storage of the water in the barrier above the tanks represents a condition where there

\footnotetext{
${ }^{1}$ http://www.wrcc.dri.edu/htmlfiles/westevap.final.html\#WASHINGTON.
} 
could be a substantial volume and driving head in the event that the water stored in the barrier were to migrate through the barrier system.

\subsection{EVAPORATIVE BARRIER WITH GRAVEL}

An evaporative barrier constructed with gravel would consist of a layer of geomembrane covered with a gravel layer. The tank farm surface would require grading to route precipitation to specific retention areas. The gravel would provide for some water storage and evaporation, while the retention areas storing the balance. This alternative minimizes the required storage capacity of the runoff retention structures. The option differs from Section 3.6 (geomembrane/geotextile combination with gravel) by having sufficient gravel to store all the water for a season.

Evaporative barriers with gravel have been excluded from this analysis. The effective evaporative depth of coarse-grained materials is limited, which would result in the accumulation of water within the barrier and the potential for standing water during the winter and spring. Additionally, collection/storage of the water in the barrier above the tanks represents a condition where there could be a substantial volume and driving head in the event of a leak through the barrier system.

\subsection{MODIFIED ASPHALT}

A modified asphalt barrier would consist of creating a sloped sub-grade over the area to be capped and then installing the asphalt cap over the tank farm using commercial paving techniques. Runoff control structures would route water away from the tank farm. Standard asphalt paving is sufficiently permeable that it is not a good candidate to prevent water from infiltrating into the subsurface. Modified asphalt products have been developed with reduced permeabilities.

Advantages of using the modified asphalt option include:

- Installation and maintenance costs are relatively low

- Environmental conditions should not affect the barrier

- Barrier can be expanded

- Allows easy access to the farm

- Easily monitored

- Can be removed if necessary

Disadvantages of using the modified asphalt option include:

- May not be applicable for other farms.

The modified asphalt material is the strongest option. The durability of the modified asphalt option with the low cost make this the most feasible option.

\subsection{SPECIALTY CONCRETE}

Specialty concrete products have current applications in building, repair of structures, reinforcement of structures (e.g., bridges and dams) and for protection of structures. This is a 
concrete like product that is on the market and claims to be well suited for waterproofing type applications.

A specialty concrete barrier would consist of a layer of material sprayed onto a prepared surface. The prepared surface would allow the concrete to bond to the base. The tank farm surface would require sloping to route precipitation to specific retention areas for evaporation or infiltration.

Specialty concrete products have been excluded from this analysis. Limited data on the performance of the material and a dearth of applications similar to an interim barrier make a full evaluation of the product impossible. The potential for specialty concrete product to crack leaving pathways for water to enter the subsurface is also a disadvantage.

\subsection{EVAPO-TRANSPIRATION BARRIER}

An evapo-transpiration barrier would consist of a layer of soil with vegetation established to aid in removing moisture from the soil. The vegetation allows the thickness of the soil layer to be reduced in comparison to an evaporative barrier. A geotextile layer over the existing gravel surface would be used to keep the soil fines from migrating into the gravel and maintain a capillary break. Water stored in the barrier either evaporates or is transpired by vegetation. The depth of the soil layer could range from 2 to 4 feet depending on the storage requirements.

Evapo-transpiration barriers have been excluded from this analysis. The amount of soil necessary to establish an evapo-transpiration barrier would be a dome loading concern. For the TY tank farm interim barrier application, the addition of 2 to 4 feet of soil would approach the allowable soil height for dome loading defined in RPP-SPEC-38937. Evapo-transpiration barriers would require limitations to personnel and vehicle access during the winter/spring when the barrier is storing water. Additionally plant growth is controlled in the tank farms to minimize the uptake of contamination in the subsurface. 


\subsection{RUNOFF ALTERNATIVES}

In addition to selecting a material/concept for an interim surface barrier application, a related decision is the selection among the available alternatives for managing and disposing of the rainwater and snowmelt shed by the barrier. The following runoff control alternatives have been identified:

- Infiltration pond near the tank farm

- Evaporation pond or evaporative system near the tank farm

- Storm water discharge system/engineered infiltration system

- $\quad$ Storage and evaporation

- $\quad$ Storage, collection, and removal to an existing water treatment facility.

\subsection{INFILTRATION POND/AREA}

The infiltration pond/area option involves constructing a lined trench to collect and route barrier runoff to a location outside of the tank farm. Grading in the tank farm causes the surface barrier to shed water to the trench. The trench collects the water and is sloped to allow water to gravity drain to an infiltration pond/area. From the infiltration pond/area, the runoff percolates into the ground away from contamination. This option resembles the lined trench and infiltration pond used for the $\mathrm{T}$ farm interim surface barrier.

Covering open trenches is recommended to prevent the accumulation of blowing sand. Trench covers are currently planned for the $T$ farm barrier to reduce the accumulation of blow sand. Also, the infiltration pond will tend to collect blowing debris and vegetation and require periodic cleanout.

The location of an infiltration pond is dependent on the facilities and waste sites near the farm and will have to be sited at a location clear of existing waste plumes as well as downhill from the barrier. This option would result in enhanced recharge near the tank farm. Uncertainties associated with the geology beneath the tank farms and the potential for the enhanced recharge to mobilize contamination warrant consideration in evaluating runoff alternatives.

\subsection{COLLECTION AND EVAPORATION POND}

This option resembles the infiltration pond option with the exception of using a lined evaporation pond instead of an infiltration pond. The evaporation pond stores the runoff until removal through evaporation. This option has the advantage of releasing no water into the soil that could speed the migration of existing contamination in or near the tank farm (for example, through lateral spreading). It has the disadvantages of requiring a larger area for evaporation than would be needed for infiltration and additional maintenance to preserve the integrity of the pond. Also, the pond may tend to collect blowing debris and vegetation and require periodic cleanout.

Having an evaporation pond with standing water present brings a host of monitoring, maintenance, and surveillance activities. Issues associated with mosquito control, tumbleweed removal, wildlife, along with the potential for blow sand to accumulate in the pond were raised 
during the investigation of this alternative. Based on these issues, this alternative warrants consideration during the evaluation of runoff alternatives.

\subsection{COLLECTION AND STORM WATER DISCHARGE SYSTEM}

This option is functionally similar to the infiltration pond with the exception of using a storm water discharge system to dispose of the water.

The storm water discharge system resembles a commercial septic system. A solids separator tank separates solids (e.g., blow sand) from water. The separation process prolongs the life of the drain field. However, it requires periodic maintenance (i.e., solids removal) for proper functioning. The drain field consists of perforated pipes, tile fields, infiltration trenches, drywells, or plastic retention/discharge systems.

This option is functionally equivalent to the infiltration pond but offers the advantage of eliminating the open pond structure. The storm water discharge system would consist of an engineered drainage and discharge field (i.e., perforated pipe similar to a septic system). This option would eliminate some of the operations/maintenance issues associated with the infiltration pond design but would still be discharging the runoff to the soil near the tank farm.

Uncertainties associated with geology beneath the tank farms and the potential for the enhanced recharge to mobilize contamination warrant consideration in evaluating runoff alternatives.

\subsection{STORAGE AND EVAPORATION}

This option involves constructing an evaporative barrier or an evapo-transpiration barrier at a designated location outside of the tank farm. Runoff from the interim surface barrier would be collected and conveyed to the evaporative system where it would be stored until it is evaporated. This option has the advantage of releasing no water into the soil that could speed the migration of existing contamination in or near the tank farm.

This option involves constructing an evaporative barrier or an evapo-transpiration barrier. Runoff from the interim surface barrier would be collected and routed to a lined evaporation basin where it would be distributed into the soil layer. The soil layer would be used to store the water until it is evaporated. With a lined basin none of the runoff would be discharged to the soil column and the precipitation that falls on the evaporative basin would be captured for subsequent evaporation. This would reduce the net recharge in the area surrounding the tank farm. With this option, the soil excavated could be replaced after the liner is installed eliminated any excess spoils. Once in place, this system would be passively operated, would not involve any operating expense, and would involve minimal maintenance.

The soil in the evaporative basin area could be vegetated or un-vegetated. In order to take advantage of plant transpiration native vegetation could be established. If the objective were to prevent any vegetation on the evaporative barrier, then a layer of gravel would be necessary to minimize wind erosion and active maintenance would be required to control plant growth. 


\subsection{STORAGE AND REMOVAL}

This option would involve construction of a retention pond either inside or outside the farm to collect barrier runoff until it could be removed. This option would be similar the evaporative pond options however the storage volume could be reduced to reflect periodic removal of the rainwater. The retention structure would contain a pump (portable or engineered) and discharge line to route runoff to a tanker for offloading at the Effluent Treatment Facility.

This option has the advantage of releasing no water into the soil that could speed the migration of existing contamination in or near the tank farm. It has the disadvantage of requiring maintenance to maintain the operability of the retention structure, pump, and discharge line. It also requires sampling of the runoff before disposal at the Effluent Treatment Facility.

This option would involve construction of a storm water retention pond either inside or outside the tank farm to collect runoff until it could be removed. This option could be configured similar to the evaporative pond alternative if the pond were lined. A permanent or portable pump transfer line system could be installed to transfer water from the retention pond to a tanker truck for transporting the water to an onsite facility such as the Effluent Treatment Facility.

This option has the advantage of not discharging water to the soil. The disadvantage is that the retention facility would require monitoring and the transfer equipment would need to be designed to operate in the winter months and maintained to ensure operability. There is also a potential requirement that the runoff water would require sampling and analysis on a batch by batch basis before it is transported to the Effluent Treatment Facility. 


\subsection{REFERENCES}

DOE/RL-99-36, 2000, Phase 1 RCRA Facility Investigation/Corrective Measures Study Work Plan for Single-Shell Tank Waste Management Areas, Revision 1, U.S. Department of Energy, Richland Operations Office, Richland, Washington.

Ecology, EPA, and DOE, 1989, Hanford Federal Facility Agreement and Consent Order, as amended, Washington State Department of Ecology, U.S. Environmental Protection Agency, and U.S. Department of Energy, Olympia, Washington.

Fayer, M.J and G.W. Gee, 2006, "Multiple-Year Water Balance of Soil Covers in a Semiarid Setting," Journal of Environmental Quality, 35:366-377 (2006). http://jeq.scijournals.org/cgi/content/abstract/35/1/366

FY-2008-ENV-M-0143, 2008, T-Farm Interim Barrier Construction and Monitoring Management Assessment Report, Revision 0, CH2M HILL Hanford Group, Inc., Richland, Washington.

Molton, P.M., 1999, "Reducing Water Infiltration Around Hanford Tanks," Forum Proceedings, May 4-6, 1999, Tech Con Program, Pacific Northwest National Laboratory, Richland, Washington.

NAP, 2007, Assessment of the Performance of Engineered Waste Containment Barriers, 2007, National Research Council, National Academies Press, Washington, D.C. http://www.nap.edu/catalog.php?record_id=11930

RPP-5002, 2001, Engineering Report Single-Shell Tank Farms Interim Measures to Limit Infiltration Through the Vadose Zone, Revision 1, CH2M HILL Hanford Group, Inc., Richland, Washington.

RPP-26157, 2005, Interim Surface Barriers, Revision 0, CH2M HILL Hanford Group, Inc., Richland, Washington.

RPP-33431, 2008, Design Analysis for T-Farm Interim Surface Barrier (TISB), Revision 0A, Washington River Protection Solutions LLC, Richland, Washington.

RPP-SPEC-38937, 2008, TY Farm Interim Surface Barrier Subsystem Specification, Rev. 0, Washington River Protection Solutions LLC, Richland, Washington.

WHC-SD-EN-AP-191, 1996, Groundwater Water Quality Assessment Monitoring Plan for Single-Shell Tank Waste Management Area S-SX, Revision 0, Westinghouse Hanford Company, Richland, Washington.

WHC-SD-WM-ES-165, 1999, Single-Shell Tank Interim Cover Study, Revision 0, Lockheed Martin Hanford Company, Richland, Washington. 
RPP-RPT-38323, Rev. 0

This page intentionally left blank. 
RPP-RPT-38323, Rev. 0

APPENDIX A

TY FARM INTERIM SURFACE BARRIER EVALUATION

A-i 
RPP-RPT-38323, Rev. 0

This page intentionally left blank.

A-ii 
The TY farm materials study analyzed seven alternatives for an interim surface barrier.

Background information specific to the TY farm are included in this appendix in Section A1.0. Assumptions utilized in the evaluation are included in Section A2.0. Details about each barrier option evaluated in the study are included in Section A3.0. Results and conclusions from the analysis of each option are listed in Section A4.0 and Section A5.0, respectively. Section A6.0 continues the discussion on runoff alternatives and Section A7.0 lists references.

The modified asphalt option has been determined to be the best alternative for use in the TY farm. A modified asphalt interim surface barrier can be constructed safely. The costs for the modified asphalt option are relatively low compared to other options. The modified asphalt option poses the fewest operational issues and allows for future flexibility. Table A-1 lists all of the options and relative scores.

Table A-1. Options and Relative Scores.

\begin{tabular}{|l|c|c|c|c|c|c|c|}
\hline \multicolumn{1}{|c|}{ Criteria } & Cost & Design & Construction & Operations & $\begin{array}{c}\text { Future } \\
\text { Implications }\end{array}$ & Other & Total \\
\hline Spray-On Polyurea & 15 & 36 & 12 & 47 & 39 & - & 149 \\
\hline $\begin{array}{l}\text { Spray-On Polyurea } \\
\text { w/Gravel }\end{array}$ & 12 & 36 & 12 & 36 & 34 & - & 130 \\
\hline Roofed Structure & 3 & 36 & 15 & 50 & 26 & - & 130 \\
\hline Geomembrane & 30 & 36 & 18 & 41 & 33 & - & 158 \\
\hline $\begin{array}{l}\text { Geomembrane, Geotextile } \\
\text { Combination w/Gravel }\end{array}$ & 27 & 36 & 18 & 30 & 28 & - & 139 \\
\hline Geosynthetic Clay Liner & - & ${ }^{1}$ Excluded & - & - & - & - & - \\
\hline Spray-On Polymer & - & ${ }^{2}$ Excluded & - & - & - & - & - \\
\hline $\begin{array}{l}\text { Evaporative Barrier with } \\
\text { Soil }\end{array}$ & - & ${ }^{1}$ Excluded & - & - & - & - & - \\
\hline $\begin{array}{l}\text { Evaporative Barrier with } \\
\text { Gravel }\end{array}$ & - & ${ }^{1}$ Excluded & - & - & - & - & - \\
\hline Modified Asphalt & 24 & 35 & 21 & 54 & 40 & - & 174 \\
\hline Specialty Concrete & - & - & - & - & - & ${ }^{3}$ Excluded & - \\
\hline $\begin{array}{l}\text { Evapo-Transpiration } \\
\text { Barrier }\end{array}$ & - & ${ }^{1}$ Excluded & - & - & - & - & - \\
\hline
\end{tabular}

${ }^{1}$ Dome Loading Concerns

${ }^{2}$ Design Life is Insufficient

${ }^{3}$ Insufficient Data for Evaluation 


\section{A1.0 BACKGROUND}

The TY tank farm is located in the 200 West area as shown in Figure A-1.

Figure A-1. Location of 241-TY Tank Farm.

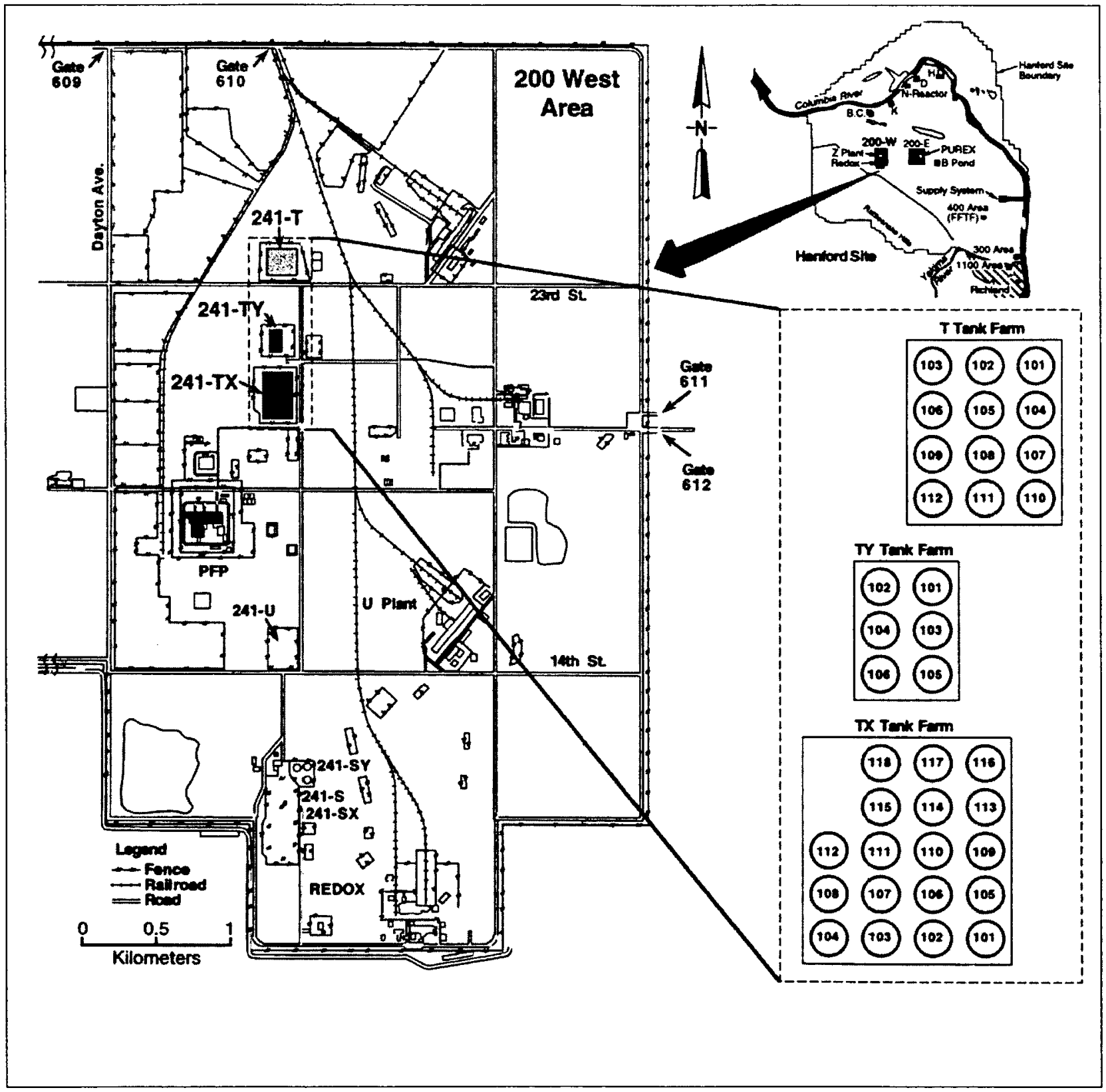

The 241-TY tank farm contains six 100-series single-shell tanks (SSTs) (241-TY-101 through TY-106). An aerial photograph of the 241-TY tank farm is shown in Figure A-2.

The 241-TY tank farm contains five tanks assumed to have leaked about 60,400 gallons of mixed-radioactive waste into the ground (Table A-2). 
Figure A-2. Aerial Photo of the 241-TY Tank Farm.

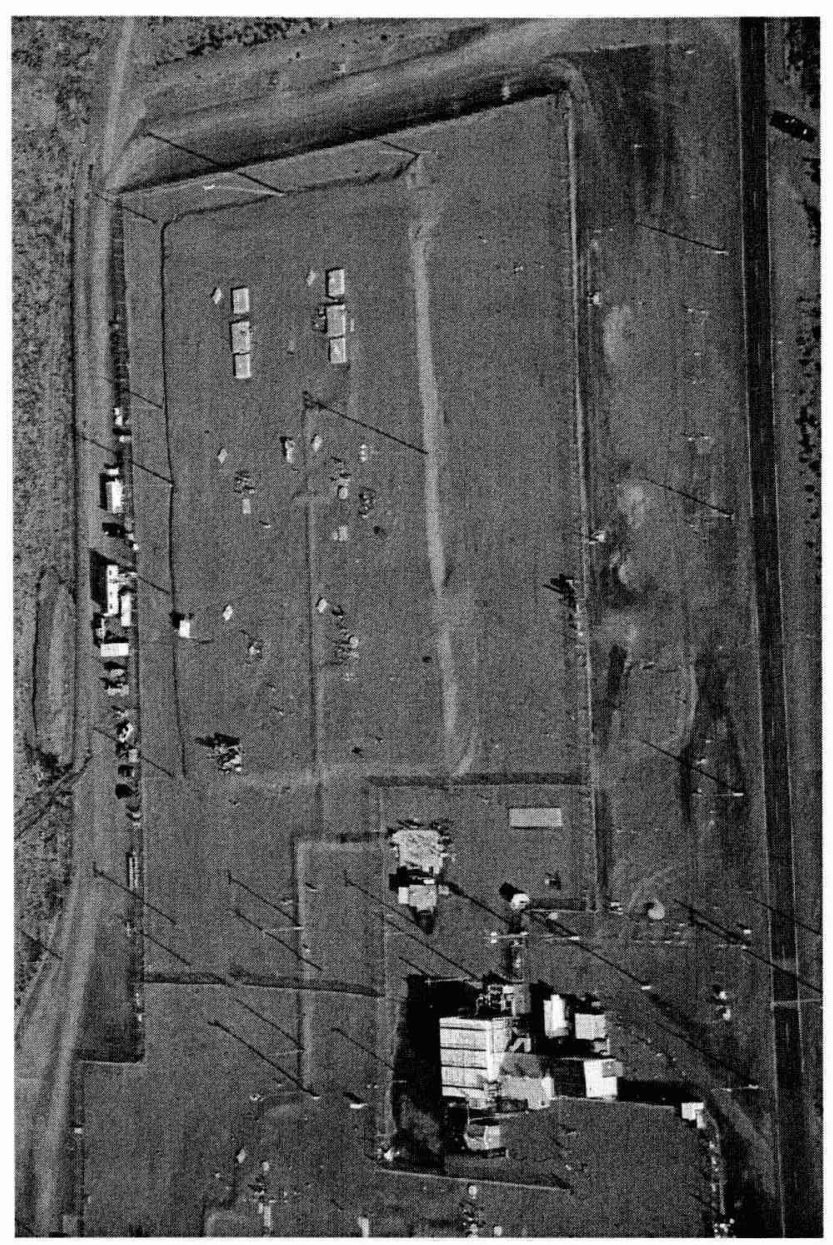

Table A-2. Status of 241-T Tank Farm Single-shell Tanks.

\begin{tabular}{|l|c|c|}
\hline \multicolumn{1}{|c|}{ Tank No. } & Assumed Leaker & $\begin{array}{c}\text { Estimated Leakage } \\
\text { (Gallon) }\end{array}$ \\
\hline $241-\mathrm{TY}-101$ & Yes & $<1,000$ \\
\hline $241-\mathrm{TY}-102$ & No & 3,000 \\
\hline $241-\mathrm{TY}-103$ & Yes & 1,400 \\
\hline $241-\mathrm{TY}-104$ & Yes & 35,000 \\
\hline $241-\mathrm{TY}-105$ & Yes & 20,000 \\
\hline $241-\mathrm{TY}-106$ & Yes & \\
\hline
\end{tabular}

Source: HNF-EP-0182, 2008, Waste Tank Summary Report for Month Ending October 31, 2008, Rev. 247, Washington River Protection Solutions LLC, Richland, Washington.

The Tank Operations Contractor (TOC) has recently completed soil characterization activity at the southern end of the tank farm. Based on the soil characterization results and the estimated leakage from the tanks within the TY farms, the U.S. Department of Energy (DOE) has decided 
that the interim surface barrier should cover the footprint of the tank farm plus the region to the south of the farm having higher soil contamination levels. The footprint of the interim barrier is shown in Figure A-3. Figure A-4 shows the layout and topography of the 241-TY tank farm. Figure A-5 shows the tank farm in plan view and identifies section lines (i.e., A-A) that correspond to profile views in Figures A-6 and A-7.

Figure A-3. 241-TY Tank Farm Barrier Footprint.

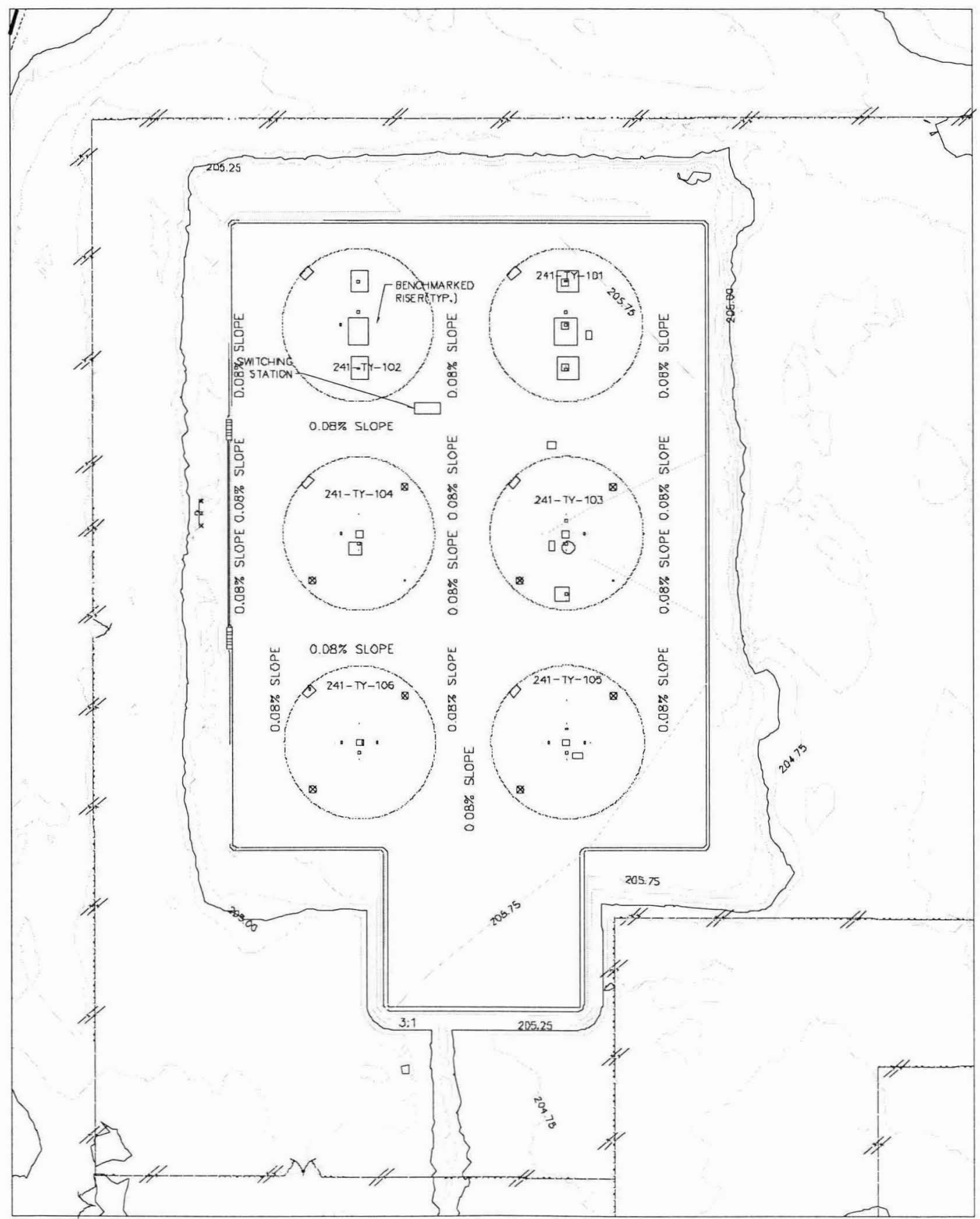


RPP-RPT-38323, Rev. 0

Figure A-4. 241-TY Tank Farm Topography.
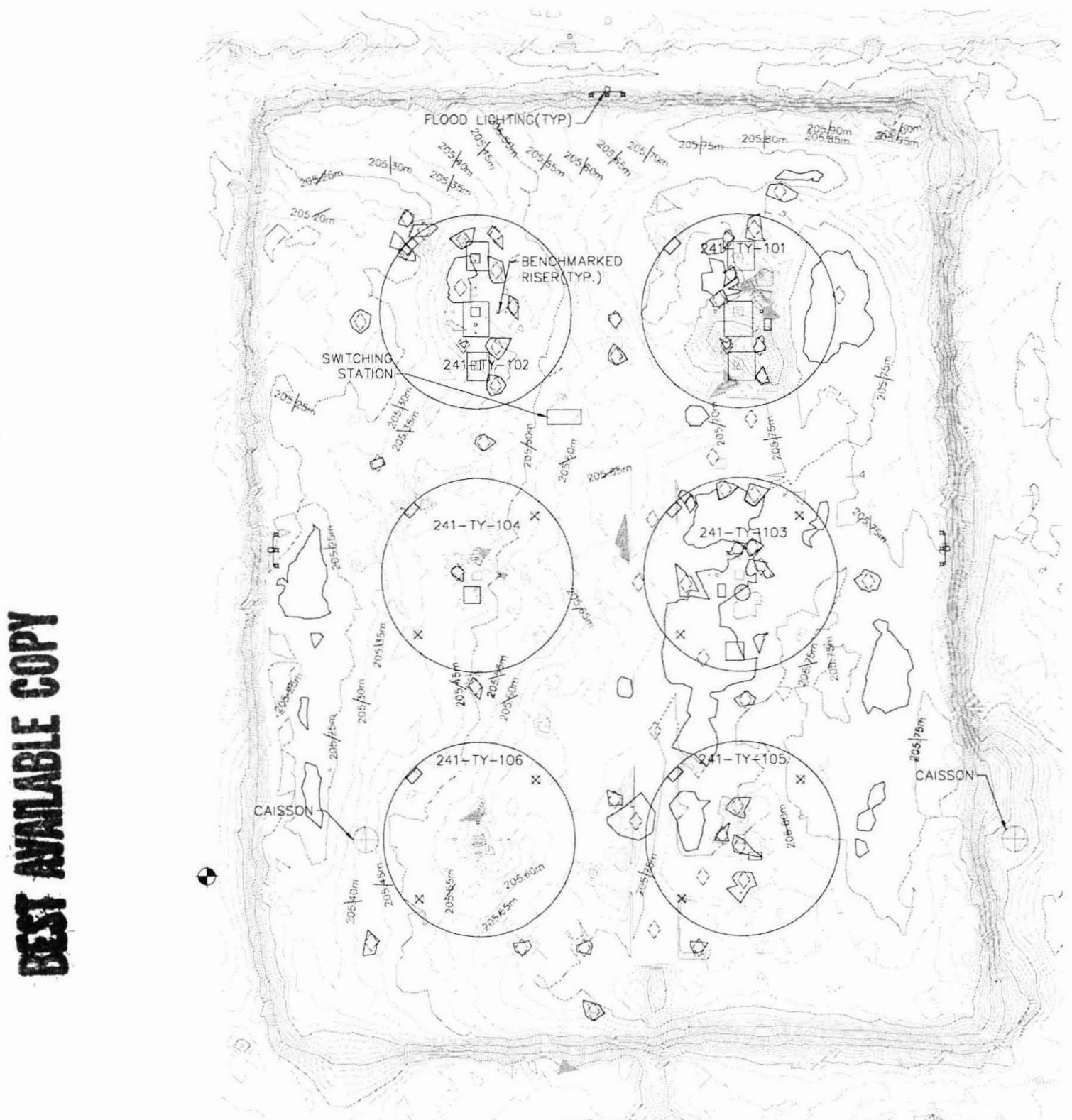

Note: topography shown is after removal of the pipeline berm. 
RPP-RPT-38323, Rev. 0

Figure A-5. 241-TY Tank Farm Profile (Overhead).

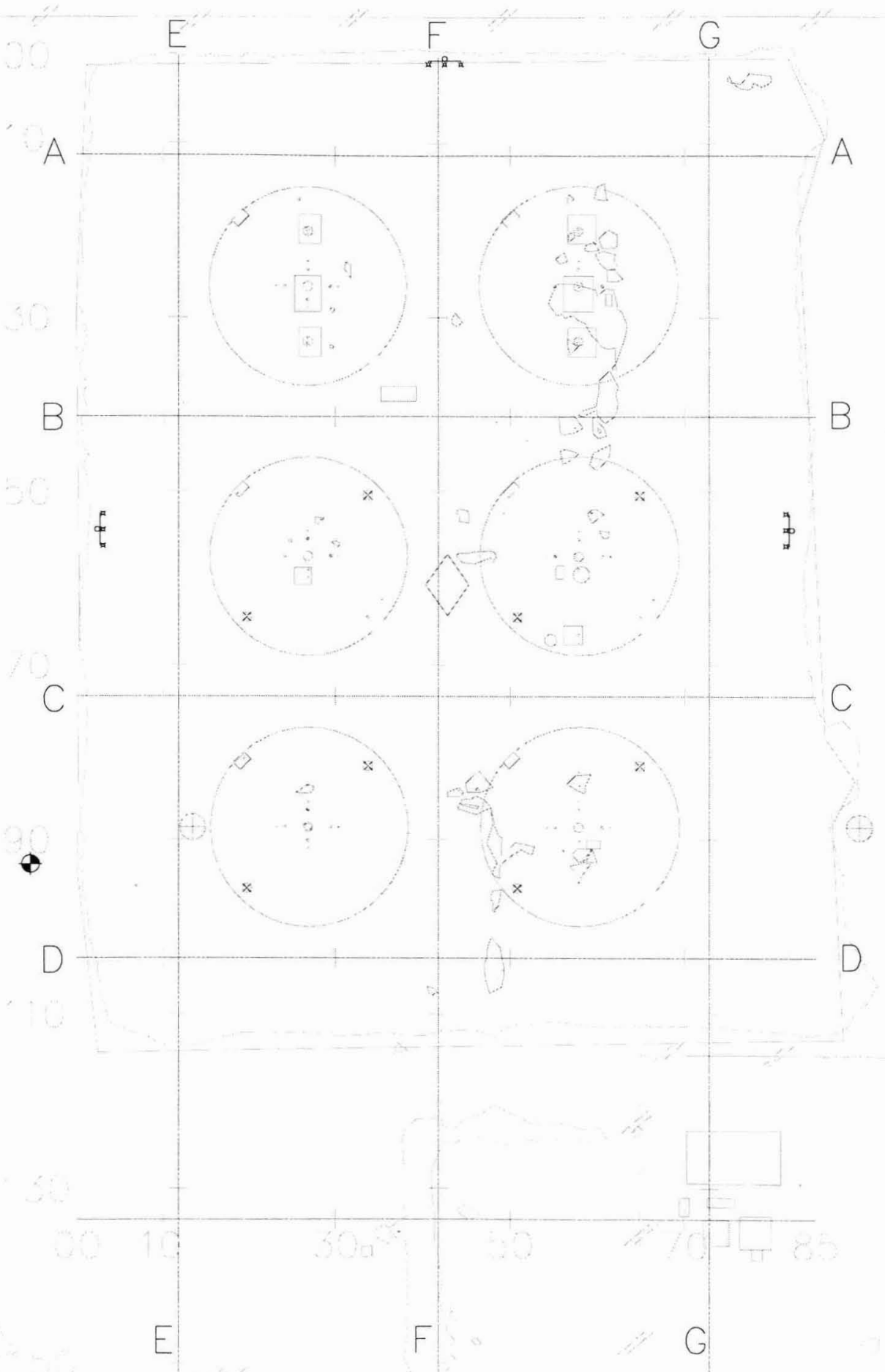


RPP-RPT-38323, Rev. 0

Figure A-6. 241-TY Tank Farm Elevation Profile (West to East).
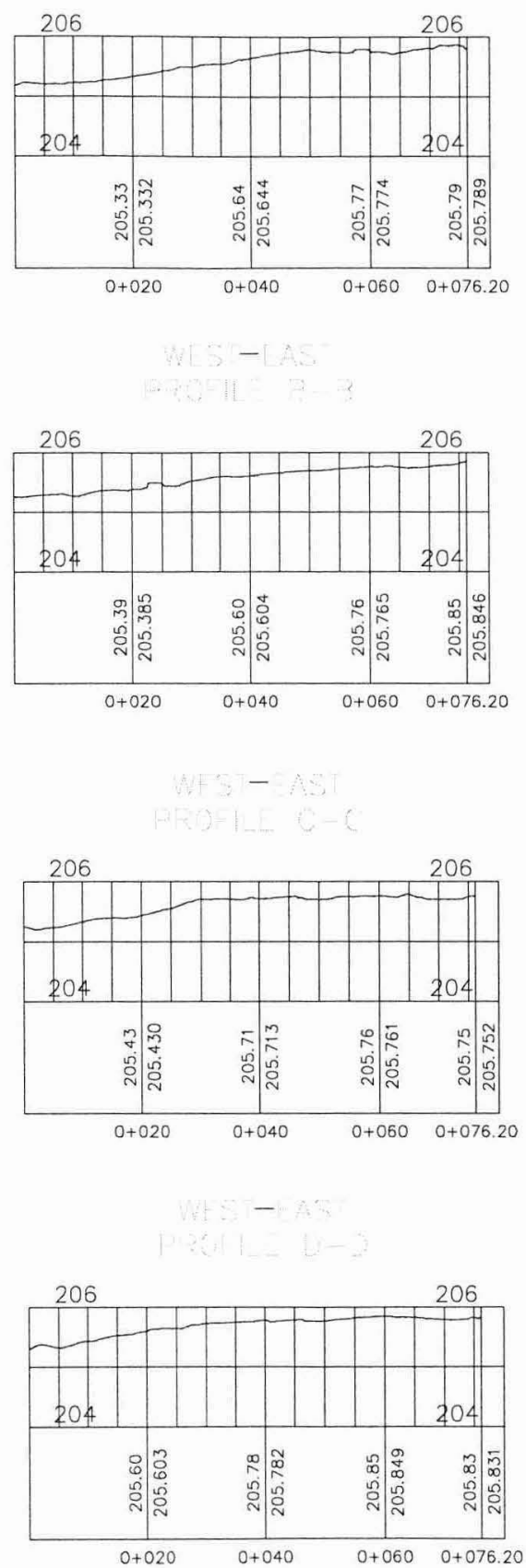

Note: Elevation values are in meters above sea level. Horizontal values are distance in meters from the left end of the section cut. 
Figure A-7. 241-TY Tank Farm Elevation Profile (North to South).
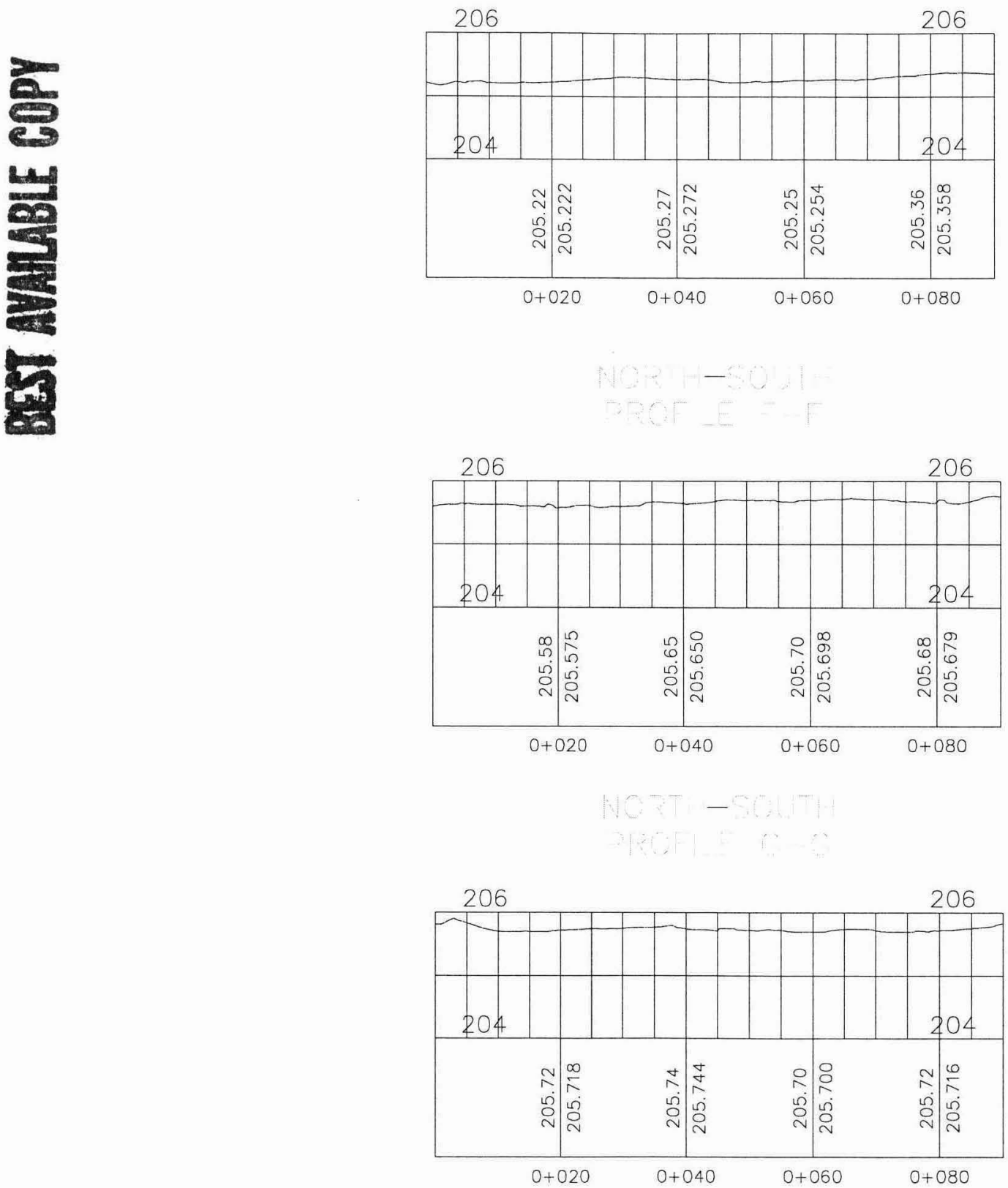

Note: Elevations shown are in meters above sea level. Horizontal axis is distance in meters from the end of the section cut. 


\section{A2.0 ASSUMPTIONS}

This evaluation makes the following assumptions.

- $\quad$ The TY interim surface barrier will have dimensions of 250 by 310 feet over the tank farm with a second area 80 by 115 feet to the south of the farm (see Figure A-3 for footprint).

- All of the options evaluated assume that standard construction equipment can be utilized in the tank farm for barrier construction activities.

- Options for the interim barrier and the management of surface water runoff can be evaluated separately.

- $\quad$ Costs are based on construction being performed during the spring, summer or fall months (i.e., temperatures above freezing).

- $\quad \mathrm{T}$ farm barrier construction costs are applicable to installation of other barriers.

- Costs are based on a five-day work week (10 hours per day). Costs associated with working weekends and/or holidays are not included in the analysis. Costs provided here are for comparative purposes and should not be used for budgeting purposes.

\section{A3.0 OPTION DEVELOPMENT}

The following sections provide a description of the interim barrier options selected for evaluation.

\section{A3.1 SPRAY-ON POLY UREA}

The spray-on polyurea interim barrier option would be similar to the interim barrier recently constructed at the 241-T tank farm. Based on lessons learned during construction of the $\mathrm{T}$ farm interim barrier, design improvements and efficiencies would be incorporated into the 241-TY farm interim barrier. Technical information from Hydro Consulting and Specialty Products, Inc. was used to support development of this option. It is assumed that the barrier footprint includes a 250- by 310 -foot area over the tank farm and an 80 - by 115 -foot area to the south of tank TY-105.

As an option to the exposed polyurea surface, the entire interim barrier surface could be covered with a layer of gravel. Covering the polyurea barrier with sand and gravel is described in this section as an optional configuration. The advantage of the gravel cover option is that the polyurea would be protected from ultraviolet exposure and the gravel would eliminate the need to construct anchor trenches around the perimeter and through the interior of the barrier. To protect the barrier material from puncture, round rock and sand would be used for the cover material. Additionally, in defined vehicle pathways the polyurea thickness may be increased to 185 mils to provide additional resistance to puncture. Nonwoven polypropylene fabric that was used in constructing the $\mathrm{T}$ farm interim barrier will be applied over the finished barrier surface providing cushion/protection from the gravel to the polyurea. The defined pathways could also be identified 
by a different color rock. Six inches of gravel over the finished surface barrier should provide sufficient weight, deterring uplift from wind. The most measurable factor of deterioration in all polymers is weathering. The rock cover would eliminate all ultraviolet exposure and deter heat gain of the finished polymer system therein, dramatically increasing its service life.

Runoff from the barrier will be collected in a lined trench or in storm drains on the west side of the farm and routed out of the tank farm.

Monitoring the integrity of the exposed polyurea barrier could be accomplished largely by visual inspection of the surface for degradation. Monitoring the covered barrier would require instrumentation and indirect methods.

Construction sequence:

1. Survey the farm surface for areas that need additional fill material.

2. Grade tank farm surface to eliminate large pooling locations. A small berm will also be created around the farm to help direct water toward the drainage system.

3. Install pipe and utility vaults around existing equipment to maintain access.

4. Place new fill material, grade, compact to establish final grade.

5. Lay geotextile into place and fit to risers and other ground penetrations.

6. Construct anchor trenches to secure barrier to the ground.

7. Spray polyurea over the geotextile.

8. Cover with an additional layer of geotextile and sand/gravel (optional).

\section{A3.1.1 Required Material and Equipment}

Ultra Bond $-100^{\mathrm{TM}}$ is the recommended polyurea material. Ultra Bond-100 is a high-tensile, highelongation, high-build fast-set elastomer specifically formulated to provide a high-strength bond to certain thermoset plastic surfaces. Unlike most spray-on polyureas, Ultra Bond-100 has the unique advantage of adhering to many polymeric substrates, both new and aged, typically without the use of primers or extensive surface preparation. Ultra Bond-100 is formulated to allow recoating with minimal surface preparation. The ultra-bond-100 is an upgrade from the polyurea formulation used at $\mathrm{T}$ farm which required cold joints to be abrasively ground back and cleaned to provide a suitable bonding surface. This requirement is eliminated with the new formulation.

\section{A3.1.2 Subgrade Requirements}

The TY-Farm surface must be graded and prepped for application of the polyurea coating. The existing surface of the 241-TY tank farm is generally sloped from east to west. The final cut and fill plan for the barrier surface needs to be defined to reflect the best balance between the existing surface (i.e., cut volume) and placement of new fill material. For the purpose of this evaluation, it is assumed that a constant 0.8 -percent slope will be necessary to facilitate 
precipitation runoff. Based on an analysis of the existing topographical information, a constant 0.8-percent slope can be established over the assumed barrier footprint by:

- $\quad$ Removing the existing pipeline berm (approximately 70 cubic yards) and using this material to fill in low spots

- $\quad$ Grading the farm to move approximately 230 cubic yards of material

- $\quad$ Adding approximately 430 cubic yards of new fill material.

\section{A3.1.3 Anchorage Requirements}

For a non-gravel covered barrier, the geotextile will be secured by means of anchorage trenches around the perimeter and through the interior. This will anchor the barrier surface to the ground and prevent the geotextile and polyurea from uplift during high wind conditions. A typical anchor trench detail is shown in Figure A-8. Anchor trenches were used in construction of the $\mathrm{T}$ farm interim polyurea barrier. If a gravel cover is chosen, no such anchorage will be required because the gravel will provide adequate weight to secure the polyurea and geotextile.

\section{Figure A-8. Typical Anchor Trench.}

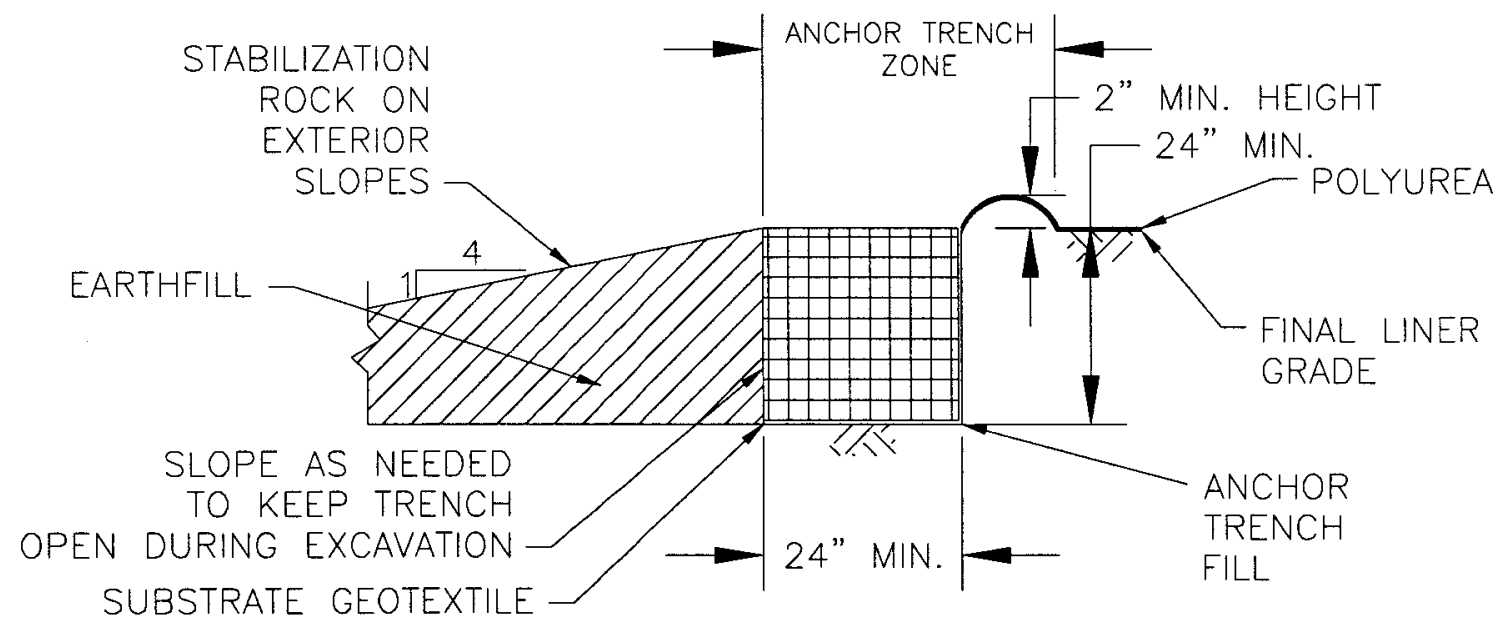

\section{A3.1.4 Schedule}

Major schedule elements associated with constructing the spray-on polyurea barrier include:

- $\quad$ Site preparation: 4-week duration assumed based on site preparation requirements at $\mathrm{T}$ farm.

- Geotextile and polyurea application: 60 days (13 weeks) based on vendor input, standard work schedules, and allowance for working in a tank farm environment. Commercial application on a prepared surface would be approximately 10 days. This schedule is 
based on operating two polyurea spray systems simultaneously. Polyurea spraying would need to be performed during warm weather months to minimize downtime. Vendor estimates for application rate are approximately 2,000 square feet per day. This translates into 43 days. Additional duration is included to provide an allowance for anchor trenches and tank farm limitations.

- Gravel cover option: an additional 10 days would be required. The installation of the polyurea barrier would be simplified by eliminating the anchor trenches; however, adding the additional geotextile and the 6-inch gravel cover will take additional time.

\section{A3.1.5 Design Issues and Concerns}

The optimal temperature to spray a polyurea barrier is above 70 degrees Fahrenheit. This restricts the construction from spring to early fall. The polyurea may be sprayed at lower temperatures, but will have decreased performance.

Labor is a major cost for constructing a polyurea barrier. A crew must be working in the tank farm grading, manually laying geotextile, and spraying the polyurea.

Maintenance of the barrier is also a concern. If there is a crack on the surface of the barrier, special equipment to spray the polyurea will be required to patch the spot. The polyurea has a relatively short shelf life and strict environmental control requirements, which make it impractical to keep on hand in case of failure. Patching material would have to be procured from the vendor at the time of repair. A trailer equipped to spray polyurea may be maintained on site to perform any repairs.

While a gravel layer will protect a polyurea barrier from ultraviolet exposure, it will also increase the difficulty in monitoring the polyurea layer for defects and conducting repairs. Additionally, the gravel layer will increase dome loading on the tanks.

\section{A3.1.6 Standard Crew Size to Construct}

During barrier construction, the polyurea application will require an approximate crew of 14 :

- 6 people for spraying polyurea

- 1 polyurea technical representative

- 2 for construction of anchor trenches

- 2 health physics technicians (HPT)

- 2 industrial hygiene technicians (IHT)

- 1 field work supervisor.

\section{A3.1.7 Polyurea Barrier Cost Estimate}

The estimated costs for a polyurea barrier at the 241-TY tank farm are presented in Table A-3 and the costs for the polyurea barrier with the gravel cover option are presented in Table A-4. 
Table A-3. Spray-on Polyurea Barrier Cost Estimate. (3 Sheets)

\begin{tabular}{|c|c|c|c|}
\hline \multicolumn{2}{|r|}{ Activity } & \multirow{2}{*}{$\begin{array}{c}\begin{array}{c}\text { Estimated } \\
\text { Cost }\end{array} \\
\$ 180,000\end{array}$} & \multirow{2}{*}{$\begin{array}{l}\text { Basis } \\
\text { T farm labor charges, 1 FTE equivalent (engineering, } \\
\text { QA, Safety, Management) for } 1 \text { year. Support } \\
\text { dependent on duration and scalable by footprint area. }\end{array}$} \\
\hline 1 & WRPS Labor & & \\
\hline \multirow[t]{8}{*}{2} & \multicolumn{3}{|l|}{ Field Work Support } \\
\hline & - Interim Covering Monitoring & $\$ 141,200$ & $\begin{array}{l}\text { T Farm Barrier Actuals at } \$ 141 \mathrm{~K} \text { for PNNL contract, } \\
\text { assume } 1 / 2 \mathrm{~T} \text { costs for TY Monitoring Plan }\end{array}$ \\
\hline & - Ground Scan & $\$ 26,500$ & $\begin{array}{l}\text { T Farm Barrier Actuals } \$ 21.5 \mathrm{~K} \text {, assume an additional } \\
\$ 5 \mathrm{~K} \text { for } \mathrm{TY} \text { barrier for additional anchor trenches }\end{array}$ \\
\hline & - Dome Deflection Surveys & $\$ 9,800$ & $\begin{array}{l}\text { T Farm Barrier Actuals, assume same costs for TY } \\
\text { barrier. May be reduced based on reduced frequency } \\
\text { of scans. }\end{array}$ \\
\hline & - Survey Services & $\$ 19,000$ & T Farm Barrier Costs, assume same costs for TY \\
\hline & - TY Barrier NEPA / CX & $\$ 13,200$ & T Farm Barrier Costs, assume same costs for TY \\
\hline & - TY Farm Vadose Monitoring & $\$ 223,400$ & $\begin{array}{l}\text { T Farm Barrier Actuals PNNL contract for monitoring } \\
\text { system design, assume } 100 \mathrm{~K} \text { for TY except as noted } \\
\text { based on the monitoring design being a modification to } \\
\text { the T barrier design. Note monitoring system } \\
\text { requirements are TBD. }\end{array}$ \\
\hline & $\begin{array}{l}\text { - Direct Push / Field Crew / } \\
\text { Lab }\end{array}$ & $\$ 300,200$ & $\begin{array}{l}\text { T Farm Barrier Actuals for direct push crew } \\
\text { (monitoring system installation), assume same costs } \\
\text { for TY barrier }\end{array}$ \\
\hline 3 & Design & $\$ 250,000$ & $\begin{array}{l}\text { Cost Estimate for completion of interim barrier design, } \\
\text { assume design costs vary depending on } \\
\text { size/complexity }\end{array}$ \\
\hline 4 & NS\&L & $\$ 0$ & No NS\&L action required \\
\hline 5 & RadCon & $\$ 4,800$ & $\begin{array}{l}\text { Assume } 2 \text { weeks for a release plan to support } \\
\text { placement of spray trailers in farm }\end{array}$ \\
\hline \multirow[t]{6}{*}{6} & \multicolumn{3}{|l|}{ Surface Preparation } \\
\hline & - Dirt work & & \\
\hline & - Cut & $\$ 150,000$ & $\begin{array}{l}\text { Based on re-grading approximately } 300 \text { yards of } \\
\text { gravel @ } \$ 500 \text { per yard }\end{array}$ \\
\hline & - Fill/compaction/grading & $\$ 215,000$ & $\begin{array}{l}\text { Based on TISB } 3,000 \text { cubic yards of clean fill placed } \\
\text { and compacted for } \$ 1.5 \text { million. This is approximately } \\
\$ 500 \text { per yard for compacted fill in the farm with } \\
\text { grading. Need } 430 \text { yards. }\end{array}$ \\
\hline & - Install Riser extensions/vaults & $\$ 0$ & Assume installation is included in the grading/fill costs \\
\hline & $\begin{array}{l}\text { - Rental equipment - earth } \\
\text { work }\end{array}$ & $\$ 80,000$ & $\begin{array}{l}\text { Based on ROM } \$ 4 \mathrm{~K} \text { per day over construction } \\
\text { duration of } 20 \text { days for earthwork }\end{array}$ \\
\hline \multirow[t]{2}{*}{7} & \multicolumn{3}{|l|}{ Material Procurement } \\
\hline & - Fill material & $\$ 0$ & $\begin{array}{l}\text { Assume fill material is obtained on site at no cost. } \\
\text { Assume transport is included in the cost per yard } \\
\text { below }\end{array}$ \\
\hline
\end{tabular}


Table A-3. Spray-on Polyurea Barrier Cost Estimate. (3 Sheets)

\begin{tabular}{|c|c|c|c|}
\hline \multicolumn{2}{|r|}{ Activity } & \multirow{2}{*}{$\begin{array}{c}\begin{array}{c}\text { Estimated } \\
\text { Cost }\end{array} \\
\$ \$ 40,000\end{array}$} & \multirow{2}{*}{$\begin{array}{l}\text { Basis } \\
\begin{array}{l}\text { Based on } 60 \text { concrete utility vaults }+10,000 \text { for } \\
\text { corrugated pipe/PVC pipe }+ \text { caps }\end{array}\end{array}$} \\
\hline & - Riser extensions/vaults & & \\
\hline & - Fabric & $\$ 26,700$ & $\begin{array}{l}\text { Fabric rolls are } 15 \text { feet by } 300 \text { feet. Will need at least } \\
20 \text { rolls at } \$ 1335 \text { each }\end{array}$ \\
\hline & - Polyurea Spray Trailers & $\$ 0$ & $\begin{array}{l}\text { Included as a rental. See "spray equipment rental" } \\
\text { below. }\end{array}$ \\
\hline & - Polyurea & $\$ 320,443$ & $\begin{array}{l}\text { Tank area plus annex for } 86,700 \text { square feet at } \\
125 \text { mils thickness requires } 6800 \text { gallons, assuming } \\
20 \% \text { loss and } \$ 39.27 \text { per gallon }\end{array}$ \\
\hline & - Miscellaneous consumables & $\$ 42,500$ & $\begin{array}{l}\text { Assume } \$ 500 \text { per day during construction (water, fuel, } \\
\text { mobile office rental, storage rental) }\end{array}$ \\
\hline \multirow[t]{10}{*}{8} & \multicolumn{3}{|l|}{ Construction } \\
\hline & - Work Package & $\$ 20,000$ & $\begin{array}{l}2 \text { work packages ( } 1 \text { for dirt work and } 1 \text { for poly } \\
\text { spraying)@ } \$ 10 \mathrm{~K} \text { per package }\end{array}$ \\
\hline & $\begin{array}{l}\text { - Construction Management } \\
\text { (WRPS) }\end{array}$ & $\$ 125,000$ & $\begin{array}{l}\text { Based on } 125 \text { days@10 hours per day@ } \$ 100 \text { per } \\
\text { hour }\end{array}$ \\
\hline & - Construction Contractor & $\$ 288,000$ & $\begin{array}{l}4 \text { FTE's equivalent for procurement/QA/Project } \\
\text { Controls/FWS/PM }\end{array}$ \\
\hline & - Tank Farm Support Crew & $\$ 192,000$ & Based on $2 \mathrm{HPT}+2$ IHT for 80 days \\
\hline & - Dirt Work (Anchor trenches) & $\$ 144,000$ & $\begin{array}{l}\text { Cost for construction of anchor trenches, } 3 \text { laborers }+1 \\
\text { operator for } 60 \text { days }\end{array}$ \\
\hline & - Spray Operators & $\$ 468,000$ & $\begin{array}{l}\text { Based on crew of } 13(6 / \text { spray gun) for } 60 \text { days }+1 \\
\text { person in spray trailer monitoring pumps. Labor at } \\
\$ 60 \text { per hour. Scalable to footprint area. }\end{array}$ \\
\hline & $\begin{array}{l}\text { Vendor Technical } \\
\text { Representatives }\end{array}$ & $\$ 82,000$ & $\begin{array}{l}\text { Based on } 1 \text { technical representative for } 60 \text { days plus } \\
\$ 10 \mathrm{~K} \text { travel }\end{array}$ \\
\hline & - Spray Equipment Rental & $\$ 192,000$ & $\begin{array}{l}\text { Trailer rental is } \$ 1500 \text { per day per trailer for ops and } \\
\$ 250 \text { per day per trailer for standby. Two trailers } \\
\text { required. Rental based on vendor quote. Estimated } \\
\text { application time is } 60 \text { work days plus } 24 \text { weekend } \\
\text { (standby) days. Need to make a buy/rent decision. }\end{array}$ \\
\hline & - Equipment Rental & $\$ 120,000$ & $\begin{array}{l}\text { Based on } \$ 2 \mathrm{~K} \text { per day for } 60 \text { days covers loader and } \\
\text { miscellaneous for anchor trench }\end{array}$ \\
\hline \multirow[t]{5}{*}{9} & \multicolumn{3}{|l|}{ Closeout } \\
\hline & - Clean up/Demobilize & $\$ 24,000$ & $\begin{array}{l}\text { Based on crew of } 8 \text { for five days. Labor at } \$ 60 \text { per } \\
\text { hour. }\end{array}$ \\
\hline & - Work Package Closeout & $\$ 12,000$ & \\
\hline & - Prepare Closeout Report & $\$ 12,000$ & \\
\hline & - Disposal & $\$ 5,000$ & Disposal of polyurea barrels \\
\hline 10 & \multicolumn{3}{|l|}{ Evaporation Pond } \\
\hline
\end{tabular}


Table A-3. Spray-on Polyurea Barrier Cost Estimate. (3 Sheets)

\begin{tabular}{|c|c|c|c|}
\hline \multicolumn{2}{|r|}{ Activity } & Estimated & Basis \\
\hline & - Construct Pond & $\$ 157,000$ & $\begin{array}{l}\text { Based on } 200 \text { feet } x 200 \text { feet lined pond } 3 \text { feet deep. } \\
\text { Excavation } 14 \text { days } @ \$ 8 \mathrm{~K} \text { per day; liner } \$ 35 \mathrm{~K} \text {; } \\
\text { installation labor at } \$ 10 \mathrm{~K} \text {. }\end{array}$ \\
\hline & $\begin{array}{l}\text { - Construct Drain from barrier } \\
\text { to evaporation pond }\end{array}$ & $\$ 22,250$ & $\begin{array}{l}\text { Based on } 250 \text { feet of buried culvert } / \mathrm{PVC} \text { pipe for } \\
\text { conveying storm water from barrier to the evaporation } \\
\text { pond. } 7 \text { days to dig/backfill@ } \$ 3 \mathrm{~K} \text { per day }+\$ 5 \text { per } \\
\text { foot for pipe }\end{array}$ \\
\hline 11 & Subtotal & $\$ 3,905,993$ & \\
\hline 12 & Total & $\$ 5,077,791$ & $\begin{array}{l}\text { Total with contingency (weather; uncertainties; } \\
\text { contingency) @ 30\% }\end{array}$ \\
\hline
\end{tabular}

Assumptions:

1. Work completed during fair season.

2. Work is construction forces.

3. Training costs for construction forces not included.

4. Durations: earthwork 20 days; spray polyurea 60 days.

5. Water disposal via an evaporation pond located to the west of the tank farm. Water disposal for area south of TY farm via local evaporation

NOTE: This cost estimate was developed for relative comparison of other TY interim barrier alternatives. This is not all inclusive and should not be used for budget purposes.

\begin{tabular}{|c|c|c|c|c|c|}
\hline FTE & $=$ & Full-time equivalent & PNNL & $=$ & Pacific Northwest National Laboratory \\
\hline FWS & $=$ & Field Work Supervisor & PVC & $=$ & polyvinyl chloride \\
\hline HPT & $=$ & health physics technicians & QA & $=$ & Quality Assurance \\
\hline IHT & $=$ & industrial hygiene technicians & ROM & $=$ & Rough order of magnitude \\
\hline NEPA & $=$ & National Environmental Policy Administration & TBD & $=$ & to be determined \\
\hline NS\&L & $=$ & Nuclear Safety and Licensing & TISB & $=$ & RPP-33431 \\
\hline PM & $=$ & Project Management & WRPS & $=$ & Washington River Protection Solutions LLC \\
\hline
\end{tabular}

Table A-4. Spray-on Polyurea Barrier Covered With Gravel Cost Estimate. (4 Sheets)

\begin{tabular}{|c|c|c|c|}
\hline \multicolumn{2}{|r|}{ Activity } & Estimated Cost & Basis \\
\hline 1 & WRPS Labor & $\$ 180,000$ & $\begin{array}{l}\text { T farm labor charges, } 1 \text { FTE equivalent } \\
\text { (engineering, QA, Safety, Management) for } 1 \\
\text { year. Support dependent on duration and scalable } \\
\text { by footprint area. }\end{array}$ \\
\hline 2 & \multicolumn{3}{|l|}{ Field Work Support } \\
\hline & - Interim Covering Monitoring & $\$ 141,200$ & $\begin{array}{l}\text { T Farm Barrier Actuals at } \$ 141 \mathrm{~K} \text { for PNNL } \\
\text { contract, assume } 1 / 2 \mathrm{~T} \text { costs for TY Monitoring } \\
\text { Plan }\end{array}$ \\
\hline & - Ground Scan & $\$ 26,500$ & $\begin{array}{l}\text { T Farm Barrier Actuals } \$ 21.5 \mathrm{~K} \text {, assume an } \\
\text { additional } \$ 5 \mathrm{~K} \text { for TY barrier for additional } \\
\text { anchor trenches }\end{array}$ \\
\hline
\end{tabular}


Table A-4. Spray-on Polyurea Barrier Covered With Gravel Cost Estimate. (4 Sheets)

\begin{tabular}{|c|c|c|c|}
\hline \multicolumn{2}{|r|}{ Activity } & \multirow{2}{*}{$\frac{\text { Estimated Cost }}{\$ 9,800}$} & \multirow{2}{*}{$\begin{array}{l}\text { Basis } \\
\text { T Farm Barrier Actuals, assume same costs for } \\
\text { TY barrier. May be reduced based on reduced } \\
\text { frequency of scans. }\end{array}$} \\
\hline & - Dome Deflection Surveys & & \\
\hline & - Survey Services & $\$ 19,000$ & T Farm Barrier Costs, assume same costs for TY \\
\hline & - TY Barrier NEPA / CX & $\$ 13,200$ & T Farm Barrier Costs, assume same costs for TY \\
\hline & - TY Farm Vadose Monitoring & $\$ 223,400$ & $\begin{array}{l}\text { T Farm Barrier Actuals PNNL contract for } \\
\text { monitoring system design, assume } 100 \mathrm{~K} \text { for TY } \\
\text { except as noted based on the monitoring design } \\
\text { being a modification to the T barrier design. Note } \\
\text { monitoring system requirements are TBD. }\end{array}$ \\
\hline & - Direct Push / Field Crew / Lab & $\$ 300,200$ & $\begin{array}{l}\text { T Farm Barrier Actuals for direct push crew } \\
\text { (monitoring system installation), assume same } \\
\text { costs for TY barrier }\end{array}$ \\
\hline 3 & Design & $\$ 250,000$ & $\begin{array}{l}\text { Cost Estimate for completion of interim barrier } \\
\text { design }\end{array}$ \\
\hline 4 & NS\&L & $\$ 0$ & No NS\&L action required \\
\hline 5 & RadCon & $\$ 4,800$ & $\begin{array}{l}\text { Assume } 2 \text { weeks for a release plan to support } \\
\text { placement of spray trailers in farm }\end{array}$ \\
\hline \multirow[t]{6}{*}{6} & \multicolumn{3}{|l|}{ Surface Preparation } \\
\hline & \multicolumn{3}{|l|}{ - Dirt work } \\
\hline & - Cut & $\$ 150,000$ & $\begin{array}{l}\text { Based on re-grading approximately } 300 \text { yards of } \\
\text { gravel @ } \$ 500 \text { per yard }\end{array}$ \\
\hline & - Fill/compaction/grading & $\$ 215,000$ & $\begin{array}{l}\text { Based on TISB } 3,000 \text { cubic yards of clean fill } \\
\text { placed and compacted for } \$ 1.5 \text { million. This is } \\
\text { approximately } \$ 500 \text { per yard for compacted fill in } \\
\text { the farm with grading. Need } 430 \text { yards }\end{array}$ \\
\hline & - Install Riser extensions/vaults & $\$ 0$ & $\begin{array}{l}\text { Assume installation is included in the grading/fill } \\
\text { costs }\end{array}$ \\
\hline & - Rental equipment - earth work & $\$ 80,000$ & $\begin{array}{l}\text { Based on ROM } \$ 4 \mathrm{~K} \text { per day over construction } \\
\text { duration of } 20 \text { days for earthwork }\end{array}$ \\
\hline \multirow[t]{5}{*}{7} & \multicolumn{3}{|l|}{ Material Procurement } \\
\hline & - Fill material & $\$ 0$ & $\begin{array}{l}\text { Assume fill material is obtained on site at no cost. } \\
\text { Assume transport is included in the cost per yard } \\
\text { below }\end{array}$ \\
\hline & - Riser extensions/vaults & $\$ 40,000$ & $\begin{array}{l}\text { Based on } 60 \text { concrete utility vaults }+10,000 \text { for } \\
\text { corrugated pipe/PVC pipe }+ \text { caps }\end{array}$ \\
\hline & - Fabric & $\$ 53,400$ & $\begin{array}{l}\text { Fabric rolls are } 15 \text { feet by } 300 \text { feet. Will need at } \\
\text { least } 20 \text { rolls under and } 20 \text { rolls over the poly } \\
\text { surface at } \$ 1335 \text { each. }\end{array}$ \\
\hline & - Polyurea Spray Trailers & $\$ 0$ & $\begin{array}{l}\text { Included as a rental. See "spray equipment rental" } \\
\text { below. }\end{array}$ \\
\hline
\end{tabular}


Table A-4. Spray-on Polyurea Barrier Covered With Gravel Cost Estimate. (4 Sheets)

\begin{tabular}{|c|c|c|c|}
\hline \multicolumn{2}{|r|}{ Activity } & \multirow{2}{*}{$\frac{\text { Estimated Cost }}{\$ 320,443}$} & \multirow{2}{*}{$\begin{array}{l}\text { Basis } \\
\text { Tank area plus annex for } 86,700 \text { square feet at } \\
125 \text { mils thickness requires } 6800 \text { gallons, } \\
\text { assuming } 20 \% \text { loss and } \$ 39.27 \text { a gallon }\end{array}$} \\
\hline & - Polyurea & & \\
\hline & - 3/4-inch Washed Rock & $\$ 32,256$ & $\begin{array}{l}\text { Based on } 2,240 \text { Ton @ } \$ 14.40 \text { per Ton (quote } \\
\text { from vendor for } 1600 \text { cubic yards) }\end{array}$ \\
\hline & - Sand & $\$ 11,592$ & $\begin{array}{l}\text { Based on } 1,120 \text { Ton } @ \$ 10.35 \text { per Ton (quote } \\
\text { from vendor for } 800 \text { cubic yards) }\end{array}$ \\
\hline & - Miscellaneous consumables & $\$ 45,000$ & $\begin{array}{l}\text { Assume } \$ 500 \text { per day during construction (water, } \\
\text { fuel, mobile office rental, storage rental) }\end{array}$ \\
\hline \multirow[t]{11}{*}{8} & \multicolumn{3}{|l|}{ Construction } \\
\hline & - Work Package & $\$ 20,000$ & $\begin{array}{l}2 \text { work packages ( } 1 \text { for dirt work and } 1 \text { for poly } \\
\text { spraying)@ } \$ 10 \mathrm{~K} \text { per package }\end{array}$ \\
\hline & - Construction Management & $\$ 125,000$ & $\begin{array}{l}\text { TISB } \$ 380 \mathrm{~K} \text { actual; } 0 \text { in original estimate - } \\
\text { based on } 125 \text { days @10 hours per day@ } \$ 100 \text { per } \\
\text { hour }\end{array}$ \\
\hline & - Construction Contractor & $\$ 324,000$ & $\begin{array}{l}4 \text { FTE's equivalent for procurement/QA/Project } \\
\text { Controls/FWS/PM }\end{array}$ \\
\hline & - Tank Farm Support Crew & $\$ 216,000$ & Based on $2 \mathrm{HPT}+2$ IHT for 90 days \\
\hline & - Dirt Work (Anchor trenches) & $\$ 0$ & $\begin{array}{l}\text { Cost for construction of anchor trenches, } 2 \\
\text { laborers for } 65 \text { days }\end{array}$ \\
\hline & - Spray Operators & $\$ 468,000$ & $\begin{array}{l}\text { Based on crew of } 13(6 / \text { spray gun) for } 60 \text { days }+1 \\
\text { person in spray trailer monitoring pumps. Labor } \\
\text { at } \$ 60 \text { per hour. }\end{array}$ \\
\hline & $\begin{array}{l}\text { - Vendor Technical } \\
\text { Representatives }\end{array}$ & $\$ 82,000$ & $\begin{array}{l}\text { Based on } 1 \text { technical representative for } 60 \text { days } \\
\text { plus } \$ 10 \mathrm{~K} \text { travel }\end{array}$ \\
\hline & - Spray Equipment Rental & $\$ 192,000$ & $\begin{array}{l}\text { Trailer rental is } \$ 1500 \text { per day per trailer for ops } \\
\text { and } \$ 250 \text { per day per trailer for standby. Two } \\
\text { trailers required. Rental based on vendor quote. } \\
\text { Estimated application time is } 60 \text { work days plus } \\
24 \text { weekend (standby) days. Need to make a } \\
\text { buy/rent decision. }\end{array}$ \\
\hline & - Rental equipment - earth work & $\$ 180,000$ & $\begin{array}{l}\text { Based on } \mathrm{ROM} \text { of } \$ 2 \mathrm{~K} \text { per day for equipment } \\
\text { rental over } 95 \text { day construction period }\end{array}$ \\
\hline & - Gravel Cover Installation & $\$ 72,000$ & $\begin{array}{l}\text { Based on crew of } 6 \text { for } 20 \text { days @ } 10 \text { hours per } \\
\text { day. Assuming } 1 \text { supervisor, } 2 \text { person crew, and } \\
3 \text { tank farm laborers. }\end{array}$ \\
\hline \multirow[t]{5}{*}{9} & \multicolumn{3}{|l|}{ Closeout } \\
\hline & - Clean up/ Demobilize & $\$ 24,000$ & $\begin{array}{l}\text { Based on crew of } 8 \text { for five days. Labor at } \$ 60 \\
\text { per hour. }\end{array}$ \\
\hline & - Work Package Closeout & $\$ 12,000$ & \\
\hline & - Prepare Closeout Report & $\$ 12,000$ & \\
\hline & - Disposal & $\$ 5,000$ & Disposal of polyurea barrels \\
\hline
\end{tabular}


RPP-RPT-38323, Rev. 0

Table A-4. Spray-on Polyurea Barrier Covered With Gravel Cost Estimate. (4 Sheets)

\begin{tabular}{|l|l|c|l|}
\hline \multicolumn{2}{|c|}{ Activity } & Estimated Cost & \multicolumn{2}{|c|}{ Basis } \\
\hline 10 & Evaporation Pond & $\$ 157,000$ & $\begin{array}{l}\text { Based on 200 feet x 200 feet lined pond 3 feet } \\
\text { deep. Excavation 14 days @ \$8K per day; liner } \\
\text { \$35K; installation labor at \$10K. }\end{array}$ \\
\cline { 2 - 5 } & - Construct Pond & $\begin{array}{l}\text { Based on 250 feet of buried culvert/PVC pipe for } \\
\text { conveying storm water from barrier to the } \\
\text { evaporation pond. 7 days to dig/backfill @ } \\
\text { • }\end{array}$ & $\begin{array}{l}\text { Construct Drain from barrier to } \\
\text { evaporation pond }\end{array}$ \\
\hline 11 & Subtotal & $\$ 22,250$ & \\
\hline 12 & Total & $\mathbf{\$ 4 , 0 2 7 , 0 4 1}$ & per foot for pipe. \\
\hline
\end{tabular}

Assumptions:

1. Work completed during fair season. 3. Training costs for construction forces not included.

2. Work is construction forces. 4 . Durations: earthwork 20 days; spray polyurea 65 days.

NOTE: This cost estimate was developed for relative comparison of other TY interim barrier alternatives. This is not all inclusive and should not be used for budget purposes.

\begin{tabular}{|c|c|c|c|c|c|}
\hline FTE & $=$ & Full-time equivalent & PNNL & $=$ & Pacific Northwest National Laboratory \\
\hline FWS & $=$ & Field Work Supervisor & PVC & $=$ & polyvinyl chloride \\
\hline HPT & $=$ & health physics technicians & QA & $=$ & Quality Assurance \\
\hline IHT & $=$ & industrial hygiene technicians & ROM & $=$ & Rough order of magnitude \\
\hline NEPA & $=$ & National Environmental Policy Administration & TBD & $=$ & to be determined \\
\hline NS\&L & $=$ & Nuclear Safety and Licensing & TISB & $=$ & RPP-33431 \\
\hline PM & $=$ & Project Management & WRPS & $=$ & Washington River Protection Solutions LLC \\
\hline
\end{tabular}

\section{A3.2 ROOFED STRUCTURE}

Both metal-roofed structures and fabric-covered structures can be designed and constructed to meet the requirements for interim barriers. Both types of structures are widely used and are available from a number of suppliers. Pre-engineered metal-roofed structures are commercially manufactured with free spans of up to 300 feet and are comparable in price to the fabric-covered structures (see Figure A-9). Metal buildings are more aligned with permanent structures although they are assembled by bolting together and can be disassembled. Examples of ClearSpan fabric structures during construction are shown in Figures A-10 and A-11. 
Figure A-9. Free Span Metal Building.

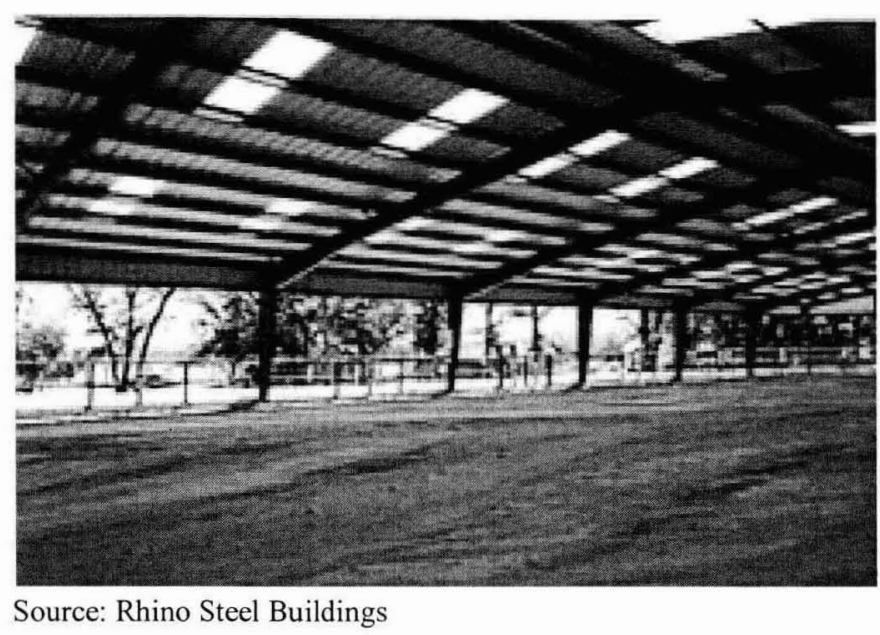

Fabric-covered structures are more aligned with the objectives of an interim barrier both for initial construction and future removal to support tank farm closure actions.

Configuration of a truss/arch fabric structure over TY farm is shown in Figures A-10 through A-14. The structure consists of the arch frame systems that are located on 10-foot centers over the length of the building. The fabric is made of woven high-density polyethylene (HDPE) scrim and is designed to last a minimum of 15 years. Because the design life of the fabric cover is less than the design life of the interim barrier, it is assumed that the fabric cover will be replaced once over the life of the barrier.

ClearSpan is one of the companies that manufactures fabric-covered structures. Examples of ClearSpan structures during construction are shown in Figures A-10 and A-11. The fabric is made of woven high-density polyethylene (HDPE) scrim and is designed to last a minimum of 15 years. Because the design life of the fabric cover is less than the design life of the interim barrier ( 25 years), replacement of the fabric cover should be considered in the material selection process.

There are a number of manufacturers that sell fabric-covered free span structures. ClearSpan is one manufacturer that has produced larger free span structures. ClearSpan has installed structures that have been in service for over nine years with no maintenance issues or problems with the fabric covers. The ClearSpan structures are designed to withstand $85 \mathrm{mph}$ winds for this area.

The building fabric-covered structures would need to be anchored to the ground. Helical anchors would be well suited to this application. A typical helical anchor installation is shown in Figure A-15. Conventional concrete footings could also be used to anchor the structures. Water runoff from the building will be collected in a gutter system or a lined trench and routed to a common collection point for subsequent discharge from the farm.

Construction sequence: 
1. Survey and locate anchor locations. This will involve a ground-penetrating radar (GPR) survey and utility survey of preselected anchor locations. Any adjustments will be made and relayed to the building manufacturer.

2. Install anchors. The anchors will be "screwed" into the soil by a specialized machine for this purpose. The anchor will be placed at either a specific depth or when the desired torque is achieved.

3. Pour concrete pad at top of each anchor.

4. Frame assembly. The frames can be assembled in place using elevated work platforms or alternately they can be assembled adjacent to the building site and lifted into place with a crane.

5. Install fabric and secure to framework.

6. Install gutters.

Figure A-10. Example ClearSpan Structure during Construction.

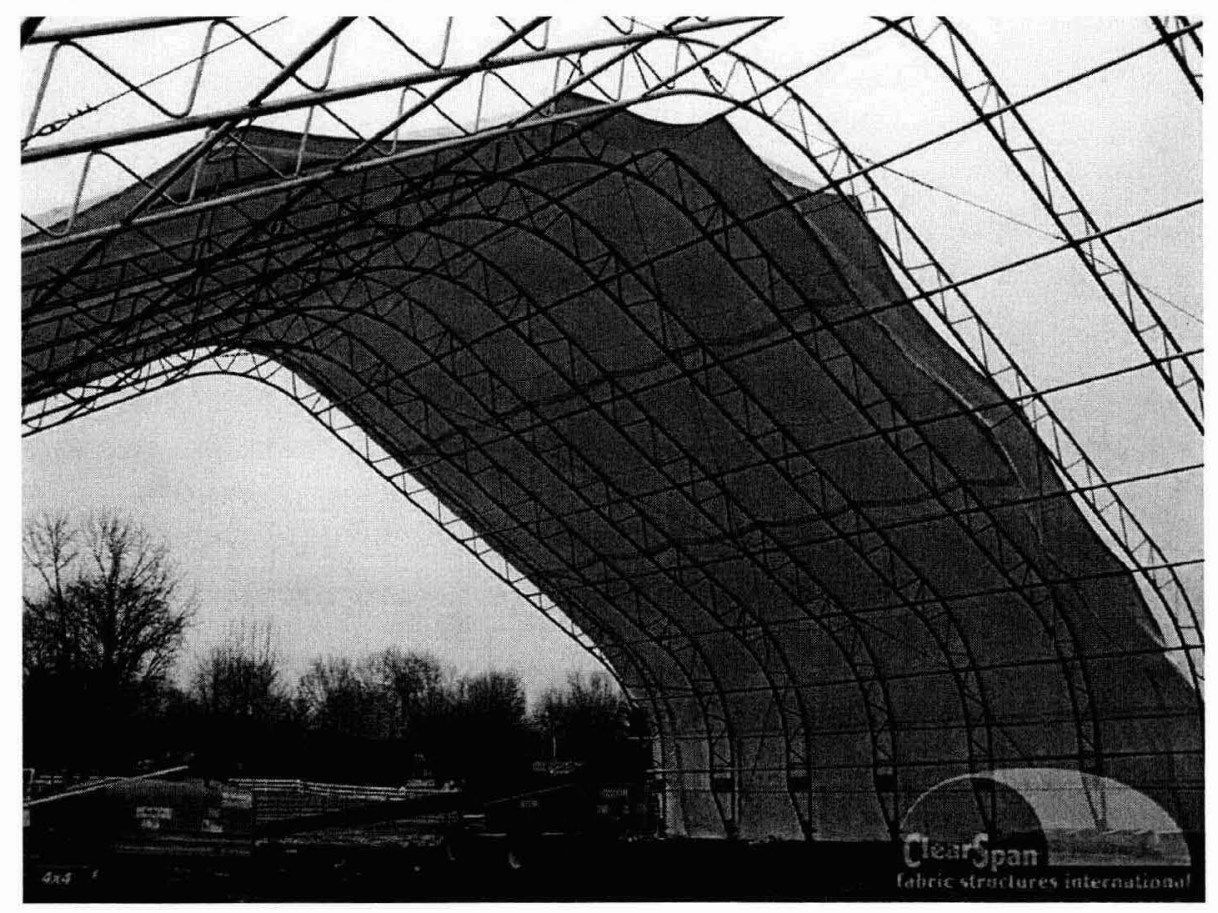

Source: ClearSpan. 
Figure A-11. Example ClearSpan Structure during Construction.

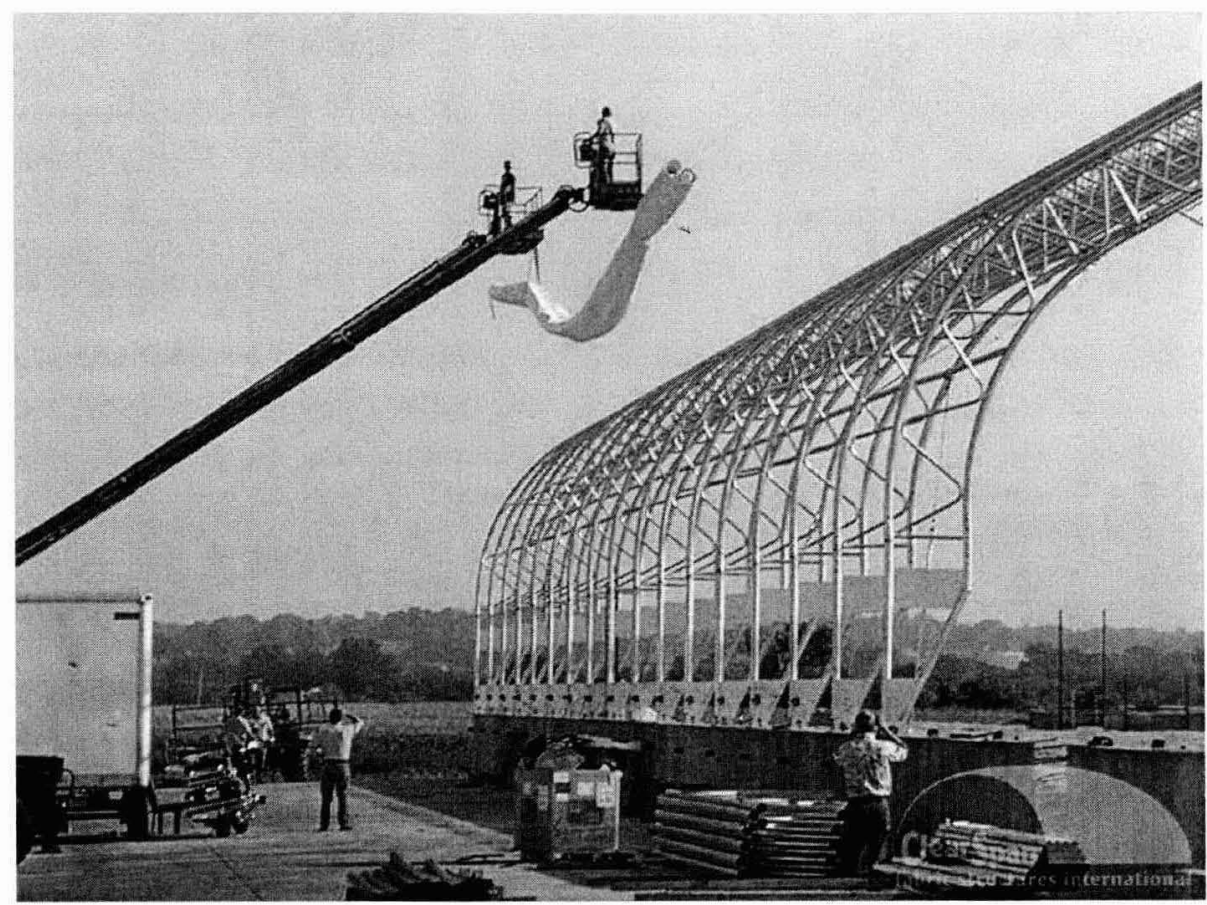

Source: ClearSpan.

Figure A-12. Truss Structure Three-Quarter View.

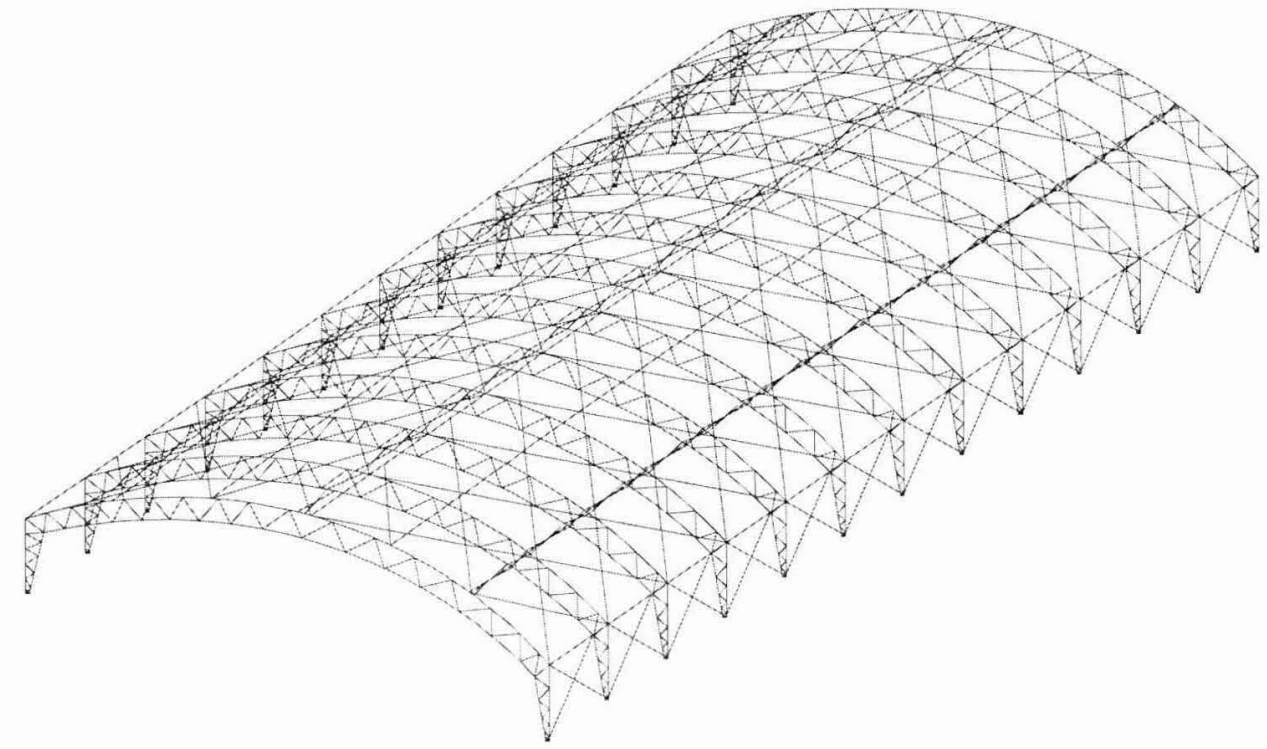


Figure A-13. Truss Structure Side View.

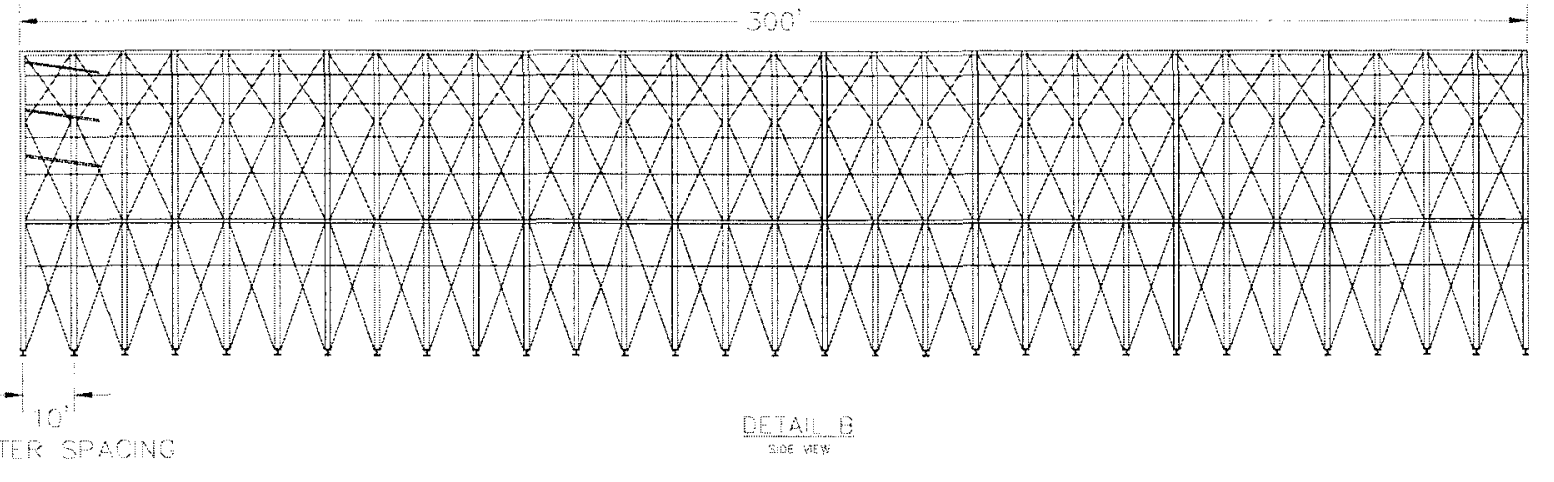

Figure A-14. Truss Structure End View.

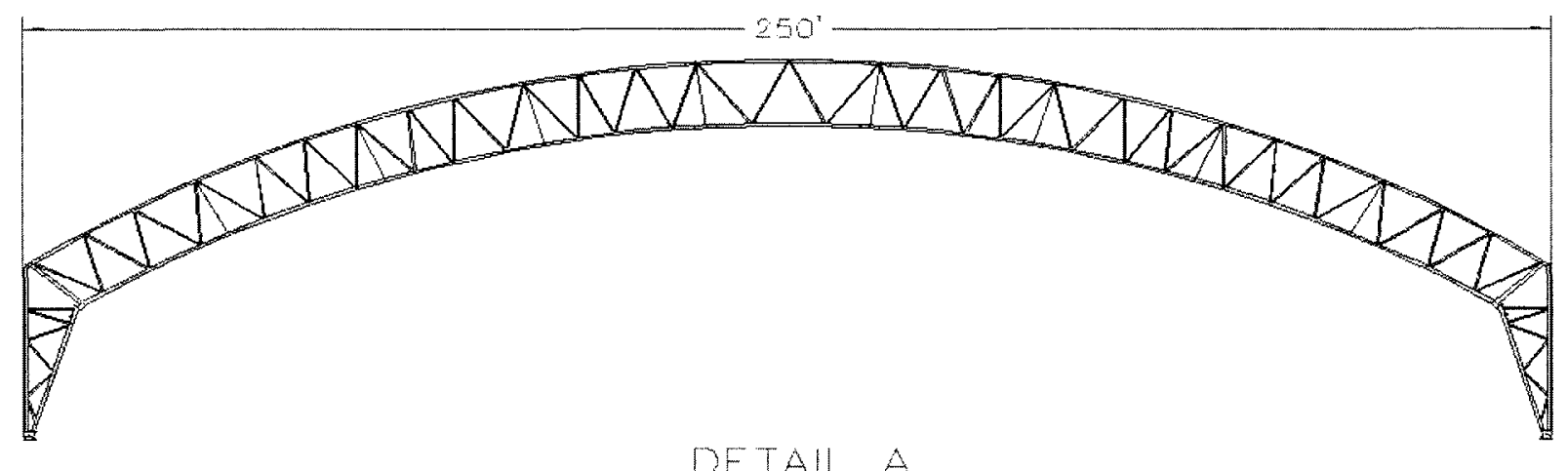

$\frac{\text { DETAIL A }}{\text { FPOMT PPOFILE WEW }}$

\section{A3.2.1 Required Material and Equipment}

- $\quad$ Building Materials. Complete building kit supplied by vendor.

- Anchors. Commercially available helical anchors (Chance Civil Construction) are recommended for this application.

- $\quad$ Anchor driver. Typically performed by a bobcat or backhoe with a specialized attachment. Anchor installation should be subcontracted which would include equipment rental for the anchor driver.

- Concrete. The concrete will cap the anchors for each truss.

- $\quad$ Crane. The crane will place the trusses upon the anchors.

- Gutter system. Commercial gutters.

- Stands. Stands to support the polyvinyl chloride (PVC) drainage pipe will need to be designed and fabricated. 
Figure A-15. Helical Anchor.

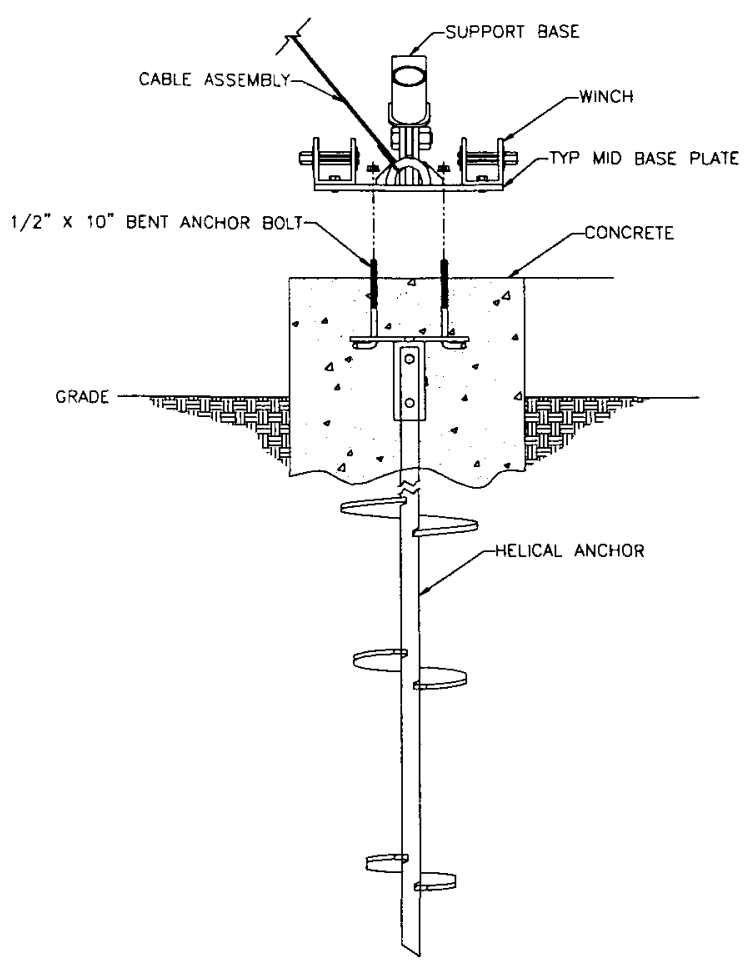

\section{A3.2.2 Site Preparation}

Prior to construction, a ground-penetrating radar (GPR) and utility survey will be competed for all anchor locations to ensure that placing of anchors will not interfere with existing tank farm infrastructure. Review of previous GPR surveys of the TY farm documented in RPP-RPT-38104, Surface Geophysical Exploration of TX-TY Farms at the Hanford Site: Results of Background Characterization with Ground Penetrating Radar, indicates there should be ample room to locate anchors around the underground infrastructure. The vendor(s) have indicated that if trusses need to be shifted to accommodate underground infrastructure, the design of the building can be modified quickly. The vendor must be provided with suitable truss locations prior to beginning construction on the building kit.

Based on the existing tank farm surface elevations, minimal surface grading or excavation will be required to establish the building site. The building will rest upon anchors placed into the ground that do not require grading of the surface.

\section{A3.2.3 Anchorage Requirements}

The fabric-covered arch building at 300-foot length will have 31 frames with a ground connection at both ends of each frame. The building design loads are an $85 \mathrm{mph}$ wind load and a 15-psf snow load. Concrete footings or helical anchors would be required to anchor the buildings down. Helical anchors are recommended for this application. These types of anchors 
have a number of advantages for use in the tank farms in terms of material requirements and labor required for installation. Helical anchors have been used at the Hanford Site on two previous projects requiring structural support at the Plutonium Finishing Plant. These anchors require no excavation or grading. The building vendor indicated that the loads at the anchorage points could be as high as 25 kips. The anchors selected for this evaluation are SS150 series anchors from Chance Civil Construction. These anchors have a 70 kip capacity in tension and compression. The building would include a rain water management system (i.e., gutters and channels) to promote drainage to a run-off collection point.

\section{A3.2.4 Schedule}

Major schedule elements associated with construction of a ClearSpan fabric structure include:

- $\quad$ GPR survey of anchor locations

- Anchor installation

- Concrete footings

- Lead time for building manufacture

- $\quad$ Building assembly installation
4 weeks

4 weeks

2 weeks

3 months

8 weeks (40 days)

\section{A3.2.5 Design Issues and Concerns}

The desired lifespan of the interim cover is 25 years. The fabric that covers the building has a 15-year warranty. If the fabric does fail, it may be replaced in sections, avoiding the need to replace the whole covering. Because of this uncertainty, it is assumed that the fabric cover will be replaced one time during the 25-year design life of the interim barrier. Replacement of the cover involves removing the ends from the winching mechanism and pulling the cover off of the building and reinstalling a new cover.

\section{A3.2.6 Standard Crew Size to Construct}

A crew of approximately 13 people will be required for construction of the ClearSpan structure as follows:

- 8 people for assembly/ installation of the building

- 2 HPTs

- 2 IHTs,

- 1 construction manager

- 3 subcontract personnel along with the tank farm support personnel for the placement of the helical anchors.

\section{A3.2.7 Fabric-covered Structure Cost Estimate}

The rough cost estimate for the fabric structure is provided in Table A-5. 
RPP-RPT-38323, Rev. 0

Table A-5. Fabric-covered Arch Structure Cost Estimate. (3 Sheets)

\begin{tabular}{|c|c|c|c|}
\hline \multicolumn{2}{|r|}{ Activity } & \multirow{2}{*}{$\frac{\text { Estimated Cost }}{\$ 180,000}$} & \multirow{2}{*}{$\begin{array}{l}\text { Basis } \\
\text { T farm labor charges, 1 FTE equivalent } \\
\text { (engineering, QA, Safety, Management) for } \\
1 \text { year. Support dependent on duration and } \\
\text { scalable by footprint area. }\end{array}$} \\
\hline 1 & WRPS Labor & & \\
\hline & - Interim Covering Monitoring & $\$ 0$ & \\
\hline & - Ground Scan & $\$ 26,500$ & $\begin{array}{l}\text { T Farm Barrier Actuals } \$ 21.5 \mathrm{~K} \text {, assume an } \\
\text { additional } \$ 5 \mathrm{~K} \text { for TY barrier for additional } \\
\text { anchor trenches }\end{array}$ \\
\hline & - Dome Deflection Surveys & $\$ 0$ & \\
\hline & - Survey Services & $\$ 0$ & \\
\hline & - TY Barrier NEPA / CX & $\$ 13,200$ & T Farm Barrier Costs, assume same costs for TY \\
\hline & - TY Farm Vadose Monitoring & $\$ 0$ & \\
\hline & - Direct Push / Field Crew / Lab & $\$ 0$ & \\
\hline 2 & Design & $\$ 250,000$ & $\begin{array}{l}\text { Cost Estimate for completion of interim barrier } \\
\text { design. }\end{array}$ \\
\hline 3 & NS\&L & & \\
\hline 4 & RadCon & $\$ 4,800$ & Assume 2 weeks for preparation of release plan. \\
\hline \multirow[t]{5}{*}{5} & \multicolumn{3}{|l|}{ Surface Preparation } \\
\hline & \multicolumn{3}{|l|}{ - Dirt work } \\
\hline & $\begin{array}{l}\text { Re-grade existing berm } \\
\sim 110 \text { cubic yards }\end{array}$ & $\$ 0$ & \\
\hline & - Fill Material & $\$ 0$ & $\begin{array}{l}\text { Based on TISB } 3,000 \text { cubic yards of clean fill } \\
\text { placed and compacted for } \$ 1.5 \text { million. This is } \\
\text { approximately } \$ 500 \text { per yard for compacted fill in } \\
\text { the farm with grading. }\end{array}$ \\
\hline & - Install Riser extensions/vaults & $\$ 0$ & \\
\hline \multirow[t]{4}{*}{6} & \multicolumn{3}{|l|}{ Material Procurement } \\
\hline & - Fill material & $\$ 0$ & Should be no material cost if obtained onsite \\
\hline & - Anchors & $\$ 165,600$ & $\begin{array}{l}\text { Based on conversation with contractor with } \\
\text { Hanford experience }\end{array}$ \\
\hline & - Concrete & $\$ 1,000$ & $\begin{array}{l}\text { 12-inch diameter, estimated average of } 2 \text { feet tall, } \\
62 \text { anchors }->100 \text { cubic feet }\end{array}$ \\
\hline & - Building Kit & $\$ 2,084,210$ & $\begin{array}{l}\text { Based on CoverAll vendor quote for } 250 \text { feet } \mathrm{x} \\
300 \text { feet scaled up to cover the } 250 \text { feet x } 300 \text { feet } \\
@ \$ 2 \mathrm{M} \text { plus quote for } 80 \text { feet x } 140 \text { feet } @ \\
\$ 84.21 \mathrm{~K}\end{array}$ \\
\hline & - Gutters & $\$ 250,000$ & Based on engineering ROM \\
\hline & - Riser extensions/vaults & $\$ 0$ & \\
\hline & - Miscellaneous consumables & $\$ 30,000$ & $\begin{array}{l}\text { Assume } \$ 500 \text { per day during construction (water, } \\
\text { fuel, mobile office rental, storage rental) }\end{array}$ \\
\hline \multirow[t]{2}{*}{7} & \multicolumn{3}{|l|}{ Construction } \\
\hline & - Work Package & $\$ 20,000$ & 2 work packages@\$10K \\
\hline
\end{tabular}


Table A-5. Fabric-covered Arch Structure Cost Estimate. (3 Sheets)

\begin{tabular}{|c|c|c|c|}
\hline \multicolumn{2}{|r|}{ Activity } & \multirow{2}{*}{$\frac{\text { Estimated Cost }}{\$ 75,000}$} & Basis \\
\hline & - Construction Management & & $\begin{array}{l}\text { TISB } \$ 380 \mathrm{~K} \text { actual; } 0 \text { in original estimate. } \\
\text { Based on } 75 \text { days @10 hours per day@ } \$ 100 \text { per } \\
\text { hour }\end{array}$ \\
\hline & - Construction Contractor & $\$ 270,000$ & $\begin{array}{l}4 \text { FTE's equivalent for procurement/QA/Project } \\
\text { Controls/FWS/PM }\end{array}$ \\
\hline & $\begin{array}{l}\text { - Ground survey anchor } \\
\text { locations }\end{array}$ & $\$ 50,000$ & $\begin{array}{l}\text { Based on similar GPR survey performed for } \\
\text { C farm direct pushes }\end{array}$ \\
\hline & - Helical anchor installation & $\$ 416,077$ & $\begin{array}{l}\text { Based on conversation with contractor with } \\
\text { Hanford experience }\end{array}$ \\
\hline & - Tank Farm Support Crew & $\$ 132,000$ & $\begin{array}{l}\text { Based on } 2 \text { HPTs and } 2 \text { IHTs over duration of } \\
\text { construction activity }\end{array}$ \\
\hline & $\begin{array}{l}\text { Vendor Technical } \\
\text { Representatives }\end{array}$ & $\$ 30,000$ & $\$ 500$ per day for two months (60 days) \\
\hline & - Equipment Rental & $\$ 440,000$ & $\begin{array}{l}\text { ROM based on } \$ 8 \mathrm{~K} \text { per day for duration of } \\
\text { construction }\end{array}$ \\
\hline & $\begin{array}{l}\text { - Structure assembly plus } \\
\text { placement }\end{array}$ & $\$ 330,000$ & $\begin{array}{l}\text { Vendor estimate of } 5 \text { weeks to complete the } 250 \text { x } \\
300 \text { structure. Added } 3 \text { weeks to assemble the } \\
140 \times 80 \text { structure. Added } 3 \text { weeks for gutter } \\
\text { installation. Based on } 55 \text { days@ @10 people @ } \\
10 \text { hours per day@ } \$ 60 \text { per hour }\end{array}$ \\
\hline & - Crane Crew & $\$ 144,000$ & $\begin{array}{l}\text { Tank farm crane crew to support lifting structure } \\
\text { frames into location. } 8 \text { weeks* } 6 \text { people @ } \\
10 \text { hours per day }\end{array}$ \\
\hline \multirow[t]{3}{*}{8} & \multicolumn{3}{|l|}{ Evaporation Pond } \\
\hline & - Construct Pond & $\$ 100,000$ & $\begin{array}{l}\text { Based on } 100 \text { feet } \times 200 \text { feet lined pond } 3 \text { feet } \\
\text { deep. Excavation } 7 \text { days } @ \$ 8 \mathrm{~K} \text { per day; liner } \\
\$ 35 \mathrm{~K} \text {; installation labor at } \$ 10 \mathrm{~K} \text {. This may be } \\
\text { scalable but not directly on surface barrier } \\
\text { footprint assume no change based on area. }\end{array}$ \\
\hline & $\begin{array}{l}\text { - Construct Drain from barrier to } \\
\text { evaporation pond }\end{array}$ & $\$ 22,250$ & $\begin{array}{l}\text { Based on } 250 \text { feet of buried culvert/PVC pipe for } \\
\text { conveying storm water from barrier to the } \\
\text { evaporation pond. } 7 \text { days to dig/backfill @ } \\
\$ 3 \mathrm{~K} \text { per day }+\$ 5 \text { per foot for pipe. }\end{array}$ \\
\hline \multirow[t]{5}{*}{9} & \multicolumn{3}{|l|}{ Closeout } \\
\hline & - Clean up/Demobilize & $\$ 24,000$ & $\begin{array}{l}\text { Based on crew of } 8 \text { for five days. Labor at } \$ 60 \\
\text { per hour. }\end{array}$ \\
\hline & - Work Package Closeout & $\$ 12,000$ & \\
\hline & - Prepare Closeout Report & $\$ 12,000$ & \\
\hline & - Disposal & & \\
\hline \multirow[t]{3}{*}{10} & Maintenance & & Required to meet design life of 25 years \\
\hline & - Replacement Cover & $\$ 287,333$ & $\begin{array}{l}\text { Material Cost for replacing fabric cover on both } \\
\text { buildings }\end{array}$ \\
\hline & - Replace Cover & $\$ 100,000$ & $\begin{array}{l}\text { Labor/planning/equipment ROM for replacing } \\
\text { fabric }\end{array}$ \\
\hline 11 & Subtotal & $\$ 5,469,971$ & \\
\hline
\end{tabular}


Figure A-16. Exposed Geomembrane Installed Around Tanks.

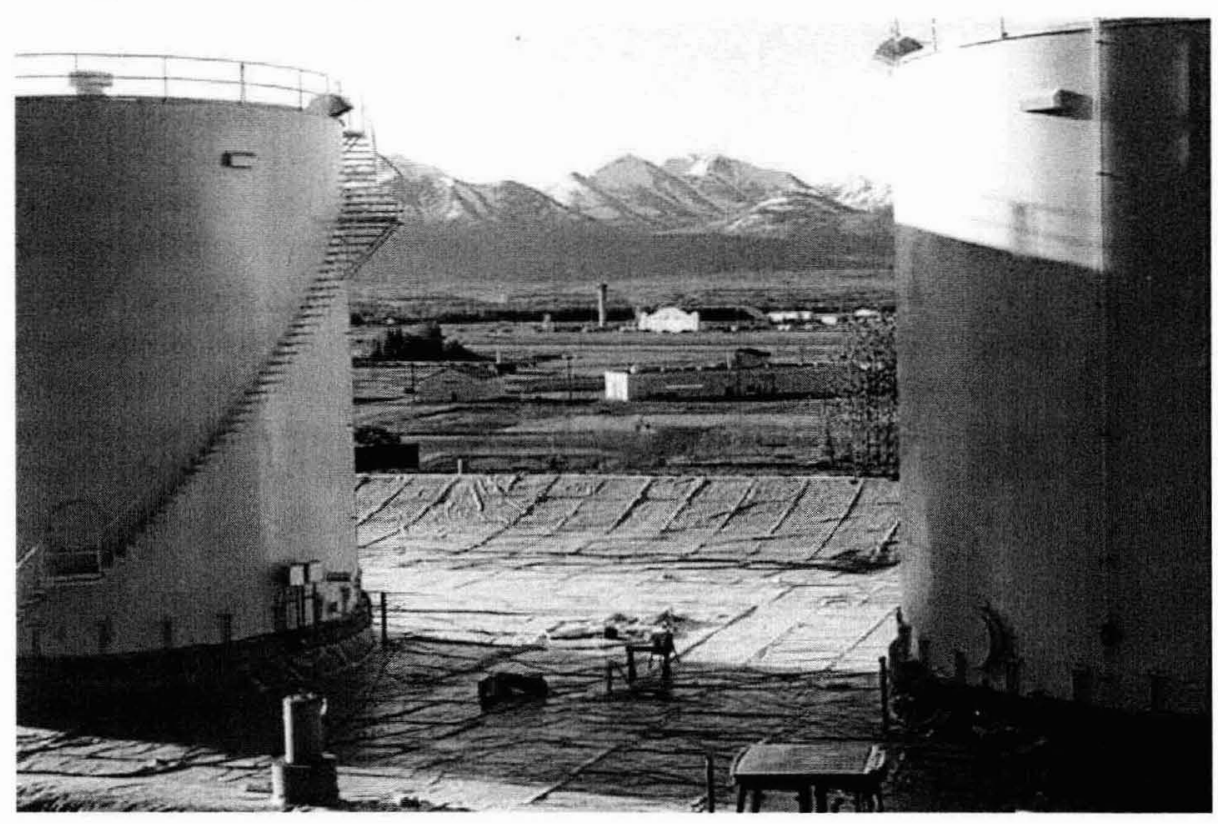

As an option to the exposed geomembrane surface the entire geomembrane surface could be covered with a layer of sand and rock. Covering the geomembrane barrier with a combination of sand, gravel, and/or washed round rock is described in this section as an optional configuration. The advantage of the gravel cover option is that the geomembrane would be protected from ultraviolet exposure and the gravel would eliminate the need to construct anchor trenches around the perimeter and through the interior of the barrier. To protect the barrier material from puncture, round rock and sand would be used for the cover material. Additionally, in defined vehicle pathways an additional layer of geomembrane can be used. Thickness of the membrane material may be increased to 185 mils to provide additional resistance to puncture. Non-woven polypropylene fabric that was used in constructing the $T$ farm interim barrier will be applied over the finished surface of barrier surface providing cushion/protection from the gravel to the polyurea. The defined pathways could also be identified by a different color rock. Six inches of gravel over the finished surface barrier should provide sufficient weight, deterring uplift from wind. The most measurable factor of deterioration in all polymers is weathering. The rock cover would eliminate all ultraviolet exposure and deter heat gain of the finished polymer system therein, dramatically increasing its service life.

All panel seams shall be fusion welded. This is performed by qualified vendor personnel. The fusion-welded seams create an air channel along the length of the seam as shown in Figure A-17. The full-length seams will be pressure tested to check the continuity of the seam. 
Figure A-17. Fusion Weld.

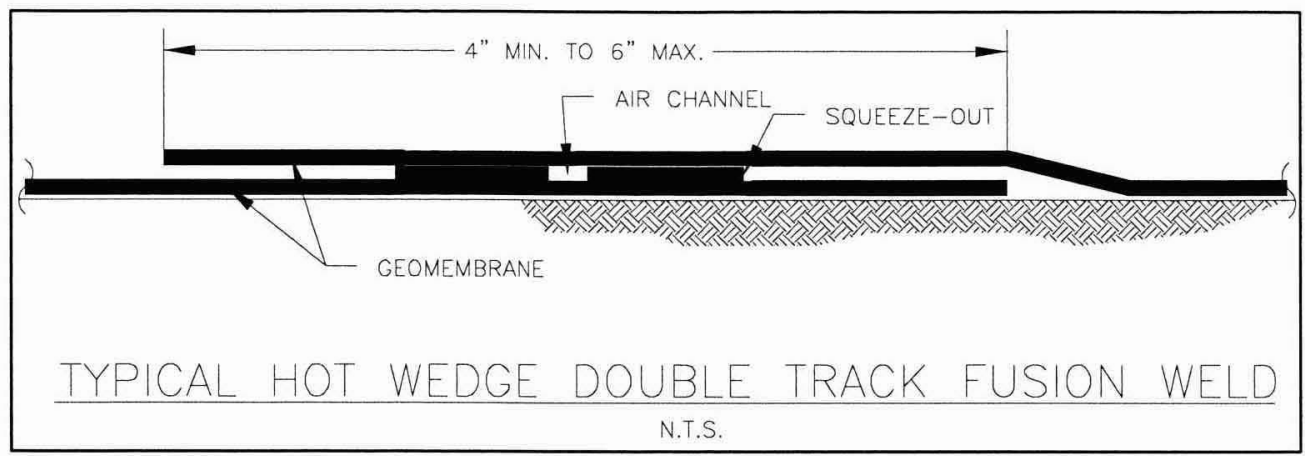

The geomembrane option would require designated traffic areas that would be constructed by adding an additional geocomposite layer between two layers of geomembrane as shown in Figure A-18. Monitoring the integrity of the exposed geomembrane could be accomplished using visual inspection and spark testing. Monitoring the gravel covered geomembrane will require instrumentation and indirect methods. Runoff from the barrier would be collected in a lined trench or in storm drains or the west sided of the farm and routed out of the farm.

Figure A-18. Roadway Detail.

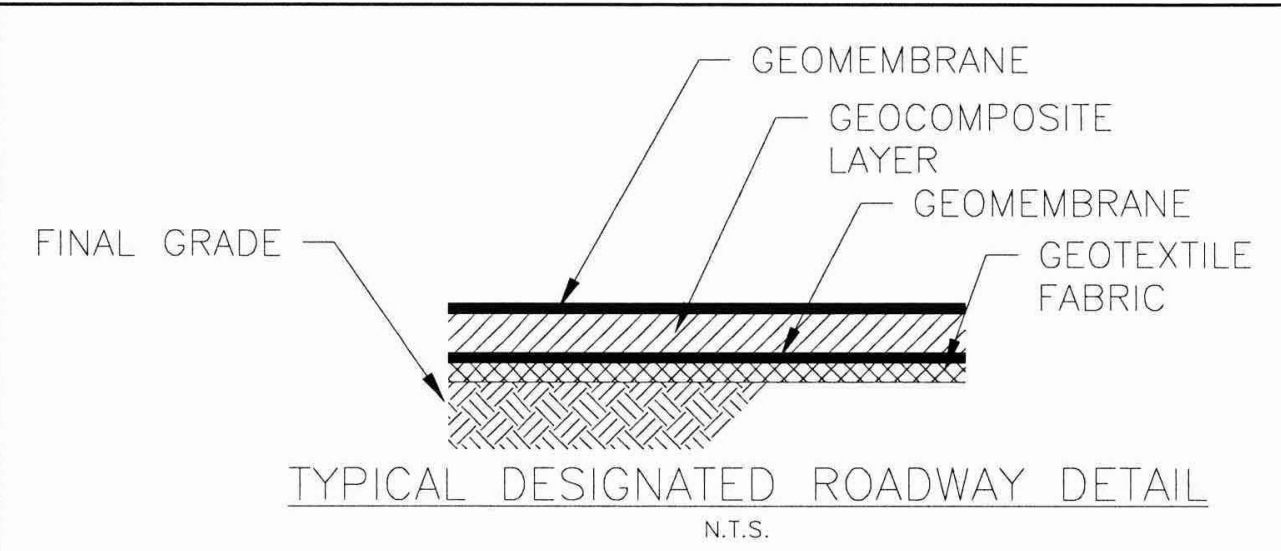

\section{Construction Sequence:}

1. Survey the farm surface for areas that need additional fill material.

2. Grade tank farm surface to provide a consistent slope. A small berm will be crated to help direct water to the drainage system.

3. Install pipe and utility vaults around existing equipment to maintain access.

4. Place new fill material, grade, compact to establish final grade.

5. Lay geotextile into place and fit to risers and other ground penetrations.

6. Construct anchor trenches to secure barrier tot he ground.

7. Install and seam geomembrane. 
Table A-5. Fabric-covered Arch Structure Cost Estimate. (3 Sheets)

\begin{tabular}{|c|l|c|l|}
\hline \multicolumn{2}{|c|}{ Activity } & Estimated Cost & \multicolumn{1}{c|}{ Basis } \\
\hline 12 & Total & $\$ \mathbf{\$ 7 1 0 , 9 6 2}$ & Weather; uncertainties; contingency @ 30\% \\
\hline
\end{tabular}

Assumptions:

1. Work completed during fair season. 3 . Training costs for construction forces not included.

2. Work is construction forces.

NOTE: This cost estimate was developed for relative comparison of other TY interim barrier alternatives. This is not all inclusive and should not be used for budget purposes.

\begin{tabular}{|c|c|c|c|c|c|}
\hline FTE & $=$ & Full-time equivalent & PM & $=$ & Project Management \\
\hline FWS & $=$ & Field Work Supervisor & PVC & $=$ & polyvinyl chloride \\
\hline GPR & $=$ & ground-penetrating radar & QA & $=$ & Quality Assurance \\
\hline HPT & $=$ & health physics technicians & ROM & $=$ & rough order of magnitude \\
\hline IHT & $=$ & industrial hygiene technicians & TISB & $=$ & RPP-33431 \\
\hline NEPA & $=$ & National Environmental Policy Administration & WRPS & $=$ & Washington River Protection Solutions LLC \\
\hline NS\&L & $=$ & Nuclear Safety and Licensing & & & \\
\hline
\end{tabular}

\section{A3.3 GEOMEMBRANE}

Geomembrane materials are widely used in industry for barrier and liner applications. A wide variety of materials are commercially produced. Geomembranes can be configured to meet the criteria for interim barriers defined in RPP-SPEC-38937, TY Farm Interim Surface Barrier Subsystem Specification. Geomembranes have been used on the Hanford Site as the liner for the Environmental Restoration Disposal Facility and at the Integrated Disposal Facility. It is assumed that the barrier footprint includes a 250- by 310-foot area over the tank farm and an 80by 115 -foot area to the south of $\operatorname{tank}$ TY-105.

Typical applications of geomembranes include liners below landfills and burial grounds and impermeable layers in engineered caps used to prevent infiltration. For these applications, the geomembrane materials are covered with soil and are not exposed. Geomembrane materials have been developed for use in direct-exposure applications.

Installation consists of placing the geotextile and geomembrane on the ground (at-grade), thermally welding the seams. Penetrations could be handled by using prefabricated components made from the geomembrane material or by using a spray-on material like polyurea. An example of an exposed geomembrane installation is provided in Figure A-16. 
RPP-RPT-38323, Rev. 0

8. Cover with an additional later of geotextile and sand/gravel (optional).

\section{A3.3.1 Required Material and Equipment}

- Geomembrane. Light reflective conductive HDPE supplied by vendor.

- Geotextile. 16-ounce nonwoven polypropylene supplied by vendor.

- Geocomposite. Synthetic cushion layer for traffic areas supplied by vendor.

- Geomembrane pipe boot. Prefabricated sleeve used to seal between pipe penetration and geomembrane supplied by vendor.

- Welding equipment. Equipment used to weld seams and pipe boots to geomembrane supplied by vendor.

- $\quad$ Spark testing equipment. Supplied by vendor.

- $\quad$ Polyurea spray. Optional supplied by vendor.

- Round rock/sand. Rock covered option only.

\section{A3.3.2 Subgrade Requirements}

The TY farm surface must be graded and prepped for application of the geomembrane. The existing surface of the 241-TY tank farm is generally sloped from east to west. The final cut and fill plan for the barrier surface needs to be defined to reflect the best balance between the existing surface (i.e., cut volume) and placement of new fill material. For the purpose of this evaluation it is assumed that a constant 0.8 -percent slope will be necessary to facilitate precipitation runoff. Based on an analysis of the existing topographical information, a constant 0.8-percent slope can be established over the assumed barrier footprint by:

- Removing the existing pipeline berm (approximately 70 cubic yards) and using this material to fill in low spots

- Grading the farm to move approximately 230 cubic yards of material

- Adding approximately 430 cubic yards of new fill material.

Once the surface grade is established, the subgrade should be compacted in accordance with design specifications, and at a minimum compacted to a level that allows construction and deployment equipment traffic without causing ruts or surface deformation. To achieve proper compaction, an additional 2 inches of clean fill is assumed to be required over the existing gravel surface to provide a smooth base for the geotextile/geomembrane installation. The finished subgrade shall be smooth and free of rocks and stones, sticks, sharp objects, or debris of any kind. No stones or other objects that will not pass freely through a 3/8-inch screen shall be present in the top 1 inch of the surface to be covered. The final grade should provide a firm unyielding foundation for the geomembrane. 


\section{A3.3.3 Anchorage Requirements}

The exposed geomembrane will require construction of anchor trenches around the perimeter and through the interior to secure the membrane preventing uplift from wind. At a minimum, anchor trenches would be required around the perimeter and interior trenches would be used as required to prevent uplift. The size of the anchor trench is determined by calculation. The covered geomembrane does not require an anchor trench.

In addition to the anchor trench the geomembrane will be attached to existing structures. Two methods of attachment are considered for attaching the geomembrane to structures. The first method uses a geotextile fabric in combination with polyurea spray. The geotextile fabric is cut to overlap the geomembrane and extend onto the pipe or other structure and the polyurea is then sprayed over the fabric until a desired thickness is achieved (see Figures A-19 and A-20). The sprayed on polyurea creates a fluid tight seal between the membrane and other structure.

Figure A-19. Pit Detail with Polyurea Option.

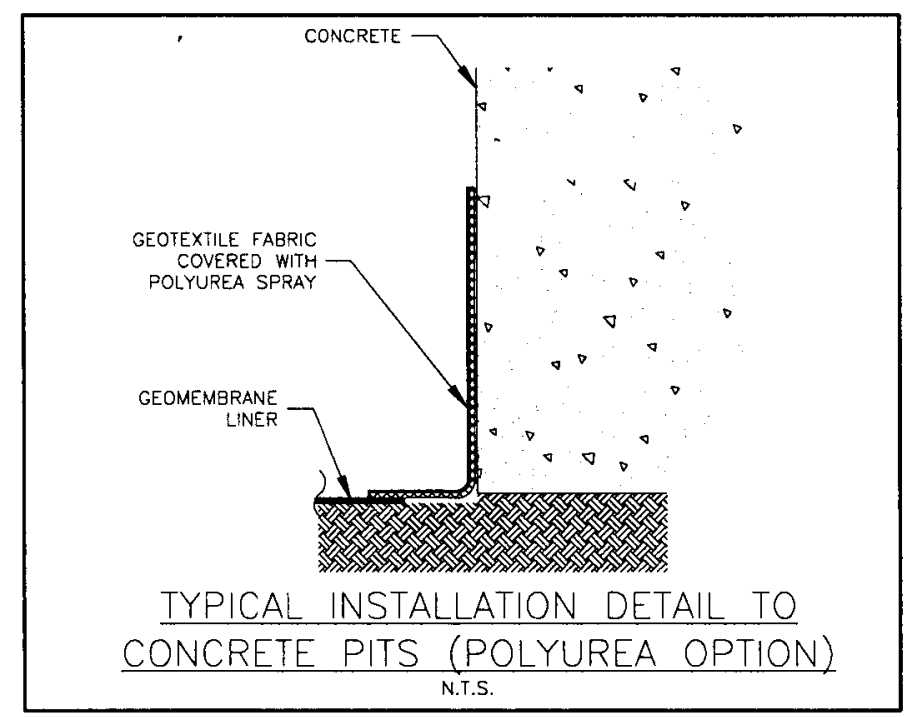


Figure A-20. Pipe Penetration Detail with Polyurea Option.

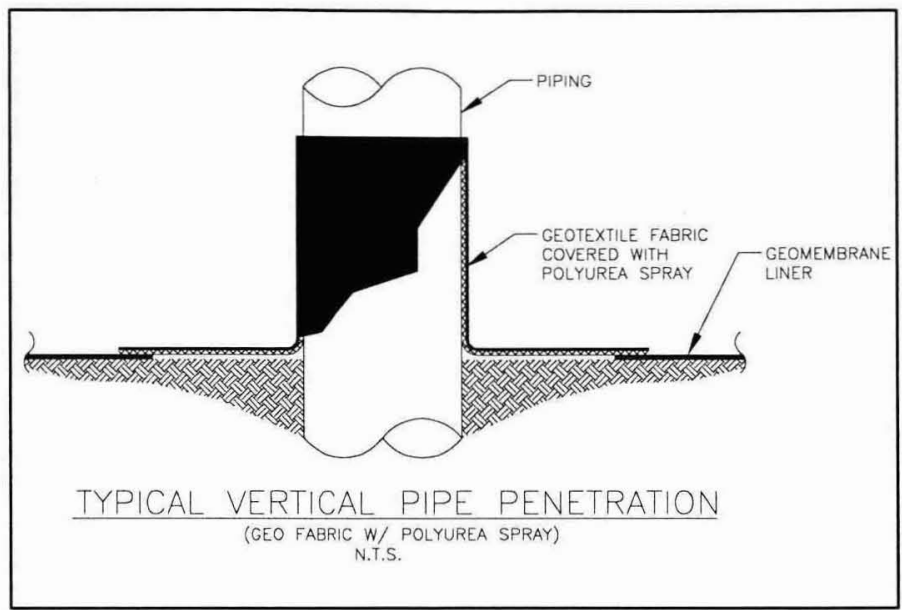

The second method for attachment is accomplished by mechanically fastening the edge of the membrane to the structure. For pipe penetrations, a prefabricated pipe boot is attached using stainless-steel banding to the pipe and extrusion welds to the membrane (see Figure A-21). At cover blocks, a stainless steel baton strap is used to fasten membrane to concrete and an extrusion weld to the membrane as shown in Figure A-22.

Figure A-21. Pipe Penetration Detail with Geomembrane Boot.

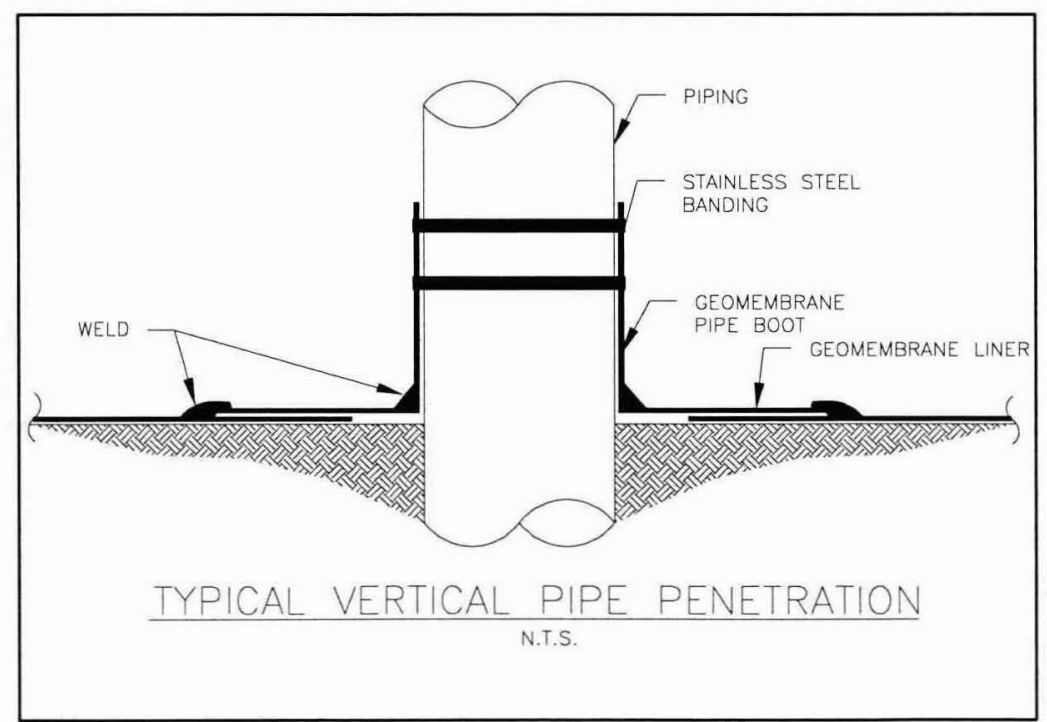


Figure A-22. Concrete Pit Detail.

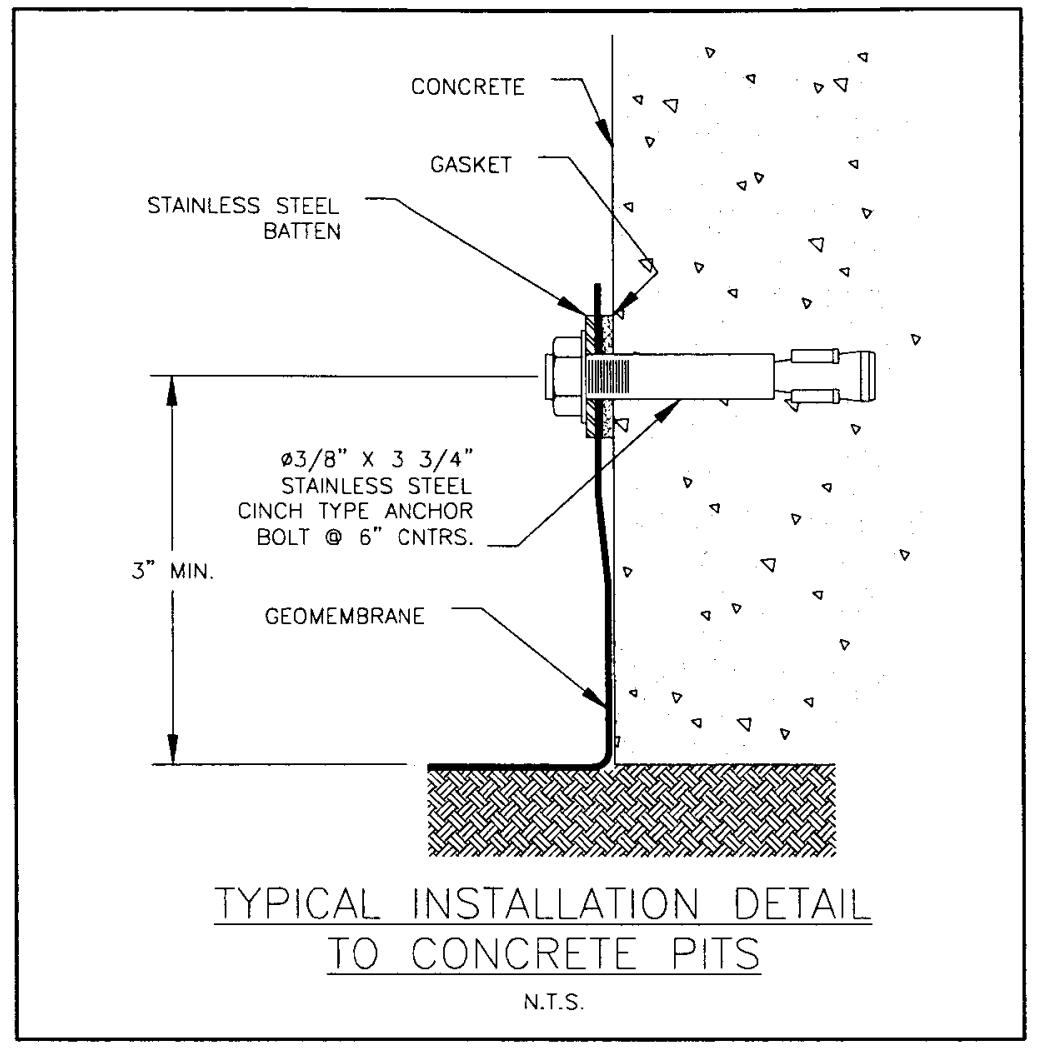

\section{A3.3.4 Schedule}

Major schedule elements associated with constructing the geomembrane barrier include:

- $\quad$ Site preparation: 20 days (4 weeks) duration assumed based on site preparation requirements at $\mathrm{T}$ farm.

- Geotextile and geomembrane application: 25 days (5 weeks) based on vendor input, standard work schedules, and allowance for working in a tank farm environment.

- Rock/sand cover option: an additional 10 days would be required. The installation of the polyurea barrier would be simplified by eliminating the anchor trenches; however, adding the additional geotextile and the 6-inch gravel cover will take additional time.

\section{A3.3.5 Design Issues and Concerns}

The desired lifespan of the interim cover is 25 years. The geomembrane has a 20 -year warranty by the vendor but has a possible service life in excess of 50 years depending on altitude, latitude, and other environmental factors.

The geomembrane materials can be repaired by replacement of material and thermally welding the new material to the barrier. Repairs to the membrane would require qualified vendor personnel. 
While a gravel layer will protect a geomembrane barrier from ultraviolet exposure, it will also increase the difficulty in monitoring the geomembrane layer for defects and conducting repairs. Additionally, the layer will increase dome loading on the tanks

\section{A3.3.6 Standard Crew Size to Construct}

The standard crew used by the vendor to install the geomembrane is estimated at 14 people. This includes:

- 10 people installing the geotextile/geomembrane

- 2 HPTs

- 2 IHTs.

\section{A3.3.7 Geomembrane Cost Estimate}

The rough cost estimate for the geomembrane barrier is presented in Table A-6 and the rough cost estimate for the geomembrane barrier covered with rock option is presented in Table A-7. In developing the estimate for the gravel-covered option, credit is taken for not having to construct anchor trenches and costs for the purchase and placement of additional geotextile and rock are included.

Table A-6. Geomembrane Cost Estimate. (3 Sheets)

\begin{tabular}{|c|c|c|c|}
\hline \multicolumn{2}{|c|}{ Activity } & \multirow{2}{*}{$\frac{\text { Estimated Cost }}{\$ 180,000}$} & \multirow{2}{*}{$\begin{array}{l}\text { Basis } \\
\text { T farm labor charges, } 1 \text { FTE equivalent } \\
\text { (engineering, QA, Safety, Management) for } 1 \\
\text { year. Support dependent on duration and scalable } \\
\text { by footprint area. }\end{array}$} \\
\hline 1 & WRPS Labor & & \\
\hline 2 & \multicolumn{3}{|l|}{ Field Work Support } \\
\hline & - Interim Covering Monitoring & $\$ 141,200$ & $\begin{array}{l}\text { T Farm Barrier Actuals at } \$ 141 \mathrm{~K} \text { for PNNL } \\
\text { contract, assume } 1 / 2 \mathrm{~T} \text { costs for TY Monitoring } \\
\text { Plan }\end{array}$ \\
\hline & - Ground Scan & $\$ 26,500$ & $\begin{array}{l}\text { T Farm Barrier Actuals } \$ 21.5 \mathrm{~K} \text {, assume an } \\
\text { additional } \$ 5 \mathrm{~K} \text { for TY barrier for additional } \\
\text { anchor trenches }\end{array}$ \\
\hline & - Dome Deflection Surveys & $\$ 9,800$ & $\begin{array}{l}\text { T Farm Barrier Actuals, assume same costs for } \\
\text { TY barrier. May be reduced based on reduced } \\
\text { frequency of scans. }\end{array}$ \\
\hline & - Survey Services & $\$ 19,000$ & T Farm Barrier Costs, assume same costs for TY \\
\hline & - TY Barrier NEPA / CX & $\$ 13,200$ & T Farm Barrier Costs, assume same costs for TY \\
\hline & - TY Farm Vadose Monitoring & $\$ 223,400$ & $\begin{array}{l}\text { T Farm Barrier Actuals PNNL contract for } \\
\text { monitoring system design, assume } 100 \mathrm{~K} \text { for TY } \\
\text { except as noted based on the monitoring design } \\
\text { being a modification to the T barrier design. Note } \\
\text { monitoring system requirements are TBD. }\end{array}$ \\
\hline
\end{tabular}


Table A-6. Geomembrane Cost Estimate. (3 Sheets)

\begin{tabular}{|c|c|c|c|}
\hline \multicolumn{2}{|c|}{ Activity } & \multirow{2}{*}{$\frac{\text { Estimated Cost }}{\$ 300,200}$} & \multirow{2}{*}{$\begin{array}{l}\text { Basis } \\
\text { T Farm Barrier Actuals for direct push crew } \\
\text { (monitoring system installation), assume same } \\
\text { costs for TY barrier }\end{array}$} \\
\hline & - Direct Push / Field Crew / Lab & & \\
\hline 3 & Design & $\$ 250,000$ & $\begin{array}{l}\text { Cost Estimate for completion of interim barrier } \\
\text { design }\end{array}$ \\
\hline 4 & NS\&L & $\$ 0$ & No NS\&L action required \\
\hline 5 & RadCon & $\$ 4,800$ & $\begin{array}{l}\text { Assume } 2 \text { weeks for a release plan to support } \\
\text { installation }\end{array}$ \\
\hline \multirow[t]{5}{*}{6} & \multicolumn{3}{|l|}{ Surface Preparation } \\
\hline & \multicolumn{3}{|l|}{ - Dirt work } \\
\hline & - Cut & $\$ 150,000$ & $\begin{array}{l}\text { Based on re-grading approximately } 300 \text { yards of } \\
\text { gravel }\end{array}$ \\
\hline & - Fill/compaction/grading & $\$ 215,000$ & $\begin{array}{l}\text { Based on TISB } 3,000 \text { cubic yards of clean fill } \\
\text { placed and compacted for } \$ 1.5 \text { million. This is } \\
\text { approximately } \$ 500 \text { per yard for compacted fill in } \\
\text { the farm with grading. }\end{array}$ \\
\hline & - Rental equipment & $\$ 80,000$ & $\begin{array}{l}\text { Based on ROM } \$ 4 \mathrm{~K} \text { per day over construction } \\
\text { duration of } 20 \text { days for earthwork }\end{array}$ \\
\hline 7 & \multicolumn{3}{|l|}{ Material Procurement } \\
\hline & - Fill material & $\$ 0$ & $\begin{array}{l}\text { Assume fill material is obtained on site at no cost. } \\
\text { Assume transport is included in the cost per yard } \\
\text { below. }\end{array}$ \\
\hline & - Riser extensions/vaults & $\$ 40,000$ & $\begin{array}{l}\text { Based on } 60 \text { concrete utility vaults }+10,000 \text { for } \\
\text { corrugated pipe/PVC pipe }+ \text { caps }\end{array}$ \\
\hline & - 100-mil HDPE & $\$ 119,218$ & $\begin{array}{l}\text { Based on coverage of } 86700 \mathrm{ft}^{2} \text { for barrier }+ \\
11100 \mathrm{ft}^{2} \text { for drive lane @ } \$ 1.219 \text { per } \mathrm{ft}^{2} \text { (quote } \\
\text { from vendor) }\end{array}$ \\
\hline & - 16 oz Geotextile & $\$ 31,732$ & $\begin{array}{l}\text { Based on coverage of } 86,700 \mathrm{ft}^{2} @ \$ 0.366 \text { per } \mathrm{ft}^{2} \\
\text { (quote from vendor) }\end{array}$ \\
\hline & - Geocomposite & $\$ 8,369$ & $\begin{array}{l}\text { Based on coverage of } 11,100 \mathrm{ft}^{2} @ \$ 0.754 \text { per } \mathrm{ft}^{2} \\
\text { (quote from vendor) }\end{array}$ \\
\hline & - Miscellaneous consumables & $\$ 22,500$ & $\begin{array}{l}\text { Assume } \$ 500 \text { per day during construction (water, } \\
\text { fuel, mobile office rental, storage rental) }\end{array}$ \\
\hline 8 & \multicolumn{3}{|l|}{ Construction } \\
\hline & - Work Package & $\$ 20,000$ & $\begin{array}{l}2 \text { work packages ( } 1 \text { for dirt work and } 1 \text { for poly } \\
\text { spraying)@ @10K per package }\end{array}$ \\
\hline & - Construction Management & $\$ 85,000$ & $\begin{array}{l}\text { Based on } 85 \text { days @10 hours per day @ } \$ 100 \text { per } \\
\text { hour }\end{array}$ \\
\hline & - Construction Contractor & $\$ 306,000$ & $\begin{array}{l}4 \text { FTE's equivalent for procurement/QA/Project } \\
\text { Controls/FWS/PM }\end{array}$ \\
\hline & - Tank Farm Support Crew & $\$ 108,000$ & $\begin{array}{l}\text { Based on } 2 \text { HPT }+2 \text { IHT for } 45 \text { days @10 hours } \\
\text { per day }\end{array}$ \\
\hline
\end{tabular}


RPP-RPT-38323, Rev. 0

Table A-6. Geomembrane Cost Estimate. (3 Sheets)

\begin{tabular}{|c|c|c|c|}
\hline \multicolumn{2}{|c|}{ Activity } & \multirow{2}{*}{$\frac{\text { Estimated Cost }}{\$ 72,000}$} & \multirow{2}{*}{$\begin{array}{l}\text { Basis } \\
\text { Cost for construction of anchor trenches, } \\
3 \text { laborers }+1 \text { operator for } 30 \text { days }\end{array}$} \\
\hline & - Dirt Work (anchor trenches) & & \\
\hline & - Vendor Installation & $\$ 150,000$ & $\begin{array}{l}\text { Based on crew of } 10 \text { for } 25 \text { days @ } 10 \text { hours per } \\
\text { day. Assuming } 1 \text { supervisor, } 4 \text { person crew, and } \\
5 \text { tank farm laborers. }\end{array}$ \\
\hline & - Rental equipment - earth work & $\$ 100,000$ & $\begin{array}{l}\text { ROM based on } \$ 4 \mathrm{~K} \text { per day for equipment rental } \\
\text { over construction period } 25 \text { days }\end{array}$ \\
\hline \multirow[t]{5}{*}{9} & \multicolumn{3}{|l|}{ Closeout } \\
\hline & - Clean up/Demobilize & $\$ 24,000$ & $\begin{array}{l}\text { Based on crew of } 8 \text { for five days. Labor at } \$ 60 \\
\text { per hour. }\end{array}$ \\
\hline & - Work Package Closeout & $\$ 12,000$ & \\
\hline & - Prepare Closeout Report & $\$ 12,000$ & \\
\hline & - Disposal & & TBD \\
\hline \multirow[t]{3}{*}{10} & \multicolumn{3}{|l|}{ Evaporation Pond } \\
\hline & - Construct Pond & $\$ 157,000$ & $\begin{array}{l}\text { Based on } 200 \text { feet x } 200 \text { feet lined pond } 3 \text { feet } \\
\text { deep. Excavation } 14 \text { days } @ \$ 8 \mathrm{~K} \text { per day; liner } \\
\$ 35 \mathrm{~K} \text {; installation labor at } \$ 10 \mathrm{~K} \text {. }\end{array}$ \\
\hline & $\begin{array}{l}\text { - Construct Drain from barrier to } \\
\text { evaporation pond }\end{array}$ & $\$ 22,250$ & $\begin{array}{l}\text { Based on } 250 \text { feet of buried culvert/PVC pipe for } \\
\text { conveying storm water from barrier to the } \\
\text { evaporation pond. } 7 \text { days to dig/backfill @ } \\
\$ 3 \mathrm{~K} \text { per day }+\$ 5 \text { per foot for pipe. }\end{array}$ \\
\hline 11 & Maintenance & 0 & Required to meet design life of 25 years \\
\hline 12 & Subtotal & $\$ 2,903,170$ & \\
\hline 13 & Total & $\$ 3,774,120$ & Weather; uncertainties; contingency@30\% \\
\hline
\end{tabular}

Assumptions:

1. Work completed during fair season.

2. Work is construction forces.

3. Training costs for construction forces not included.

NOTE: This cost estimate was developed for relative comparison of other TY interim barrier alternatives. This is not all inclusive and should not be used for budget purposes.

\begin{tabular}{|c|c|c|c|c|c|}
\hline FTE & $=$ & Full-time equivalent & PNNL & $=$ & Pacific Northwest National Laboratory \\
\hline FWS & $=$ & Field Work Supervisor & PVC & $=$ & polyvinyl chloride \\
\hline HDPE & $=$ & high-density polyethylene & QA & $=$ & Quality Assurance \\
\hline HPT & $=$ & health physics technicians & ROM & $=$ & rough order of magnitude \\
\hline IHT & $=$ & industrial hygiene technicians & TBD & $=$ & to be determined \\
\hline NEPA & $=$ & National Environmental Policy Administration & TISB & $=$ & RPP-33431 \\
\hline NS\&L & $=$ & Nuclear Safety and Licensing & WRPS & $=$ & Washington River Protection Solutions LLC \\
\hline PM & $=$ & Project Management & & & \\
\hline
\end{tabular}


Table A-7. Gravel-covered Geomembrane Cost Estimate. (3 Sheets)

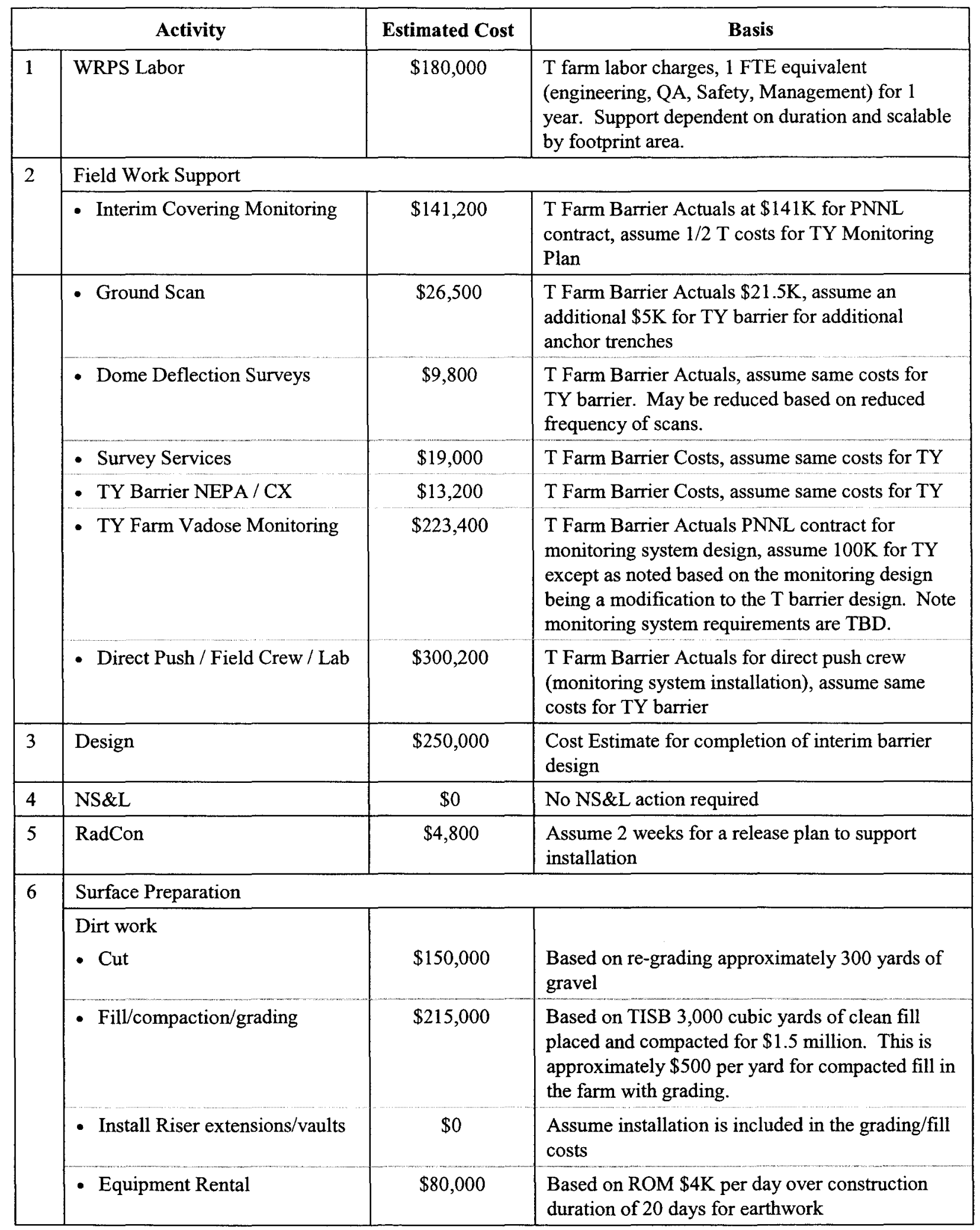


Table A-7. Gravel-covered Geomembrane Cost Estimate. (3 Sheets)

\begin{tabular}{|c|c|c|c|}
\hline \multicolumn{2}{|r|}{ Activity } & Estimated Cost & Basis \\
\hline \multirow[t]{9}{*}{7} & \multicolumn{3}{|l|}{ Material Procurement } \\
\hline & - Fill material & $\$ 0$ & $\begin{array}{l}\text { Assume fill material is obtained on site at no cost. } \\
\text { Assume transport is included in the cost per yard } \\
\text { below. }\end{array}$ \\
\hline & - Riser extensions/vaults & $\$ 40,000$ & $\begin{array}{l}\text { Based on } 60 \text { concrete utility vaults }+10,000 \text { for } \\
\text { corrugated pipe/PVC pipe }+ \text { caps }\end{array}$ \\
\hline & - 100-mil HDPE & $\$ 119,218$ & $\begin{array}{l}\text { Based on coverage of } 97,800 \mathrm{ft}^{2} @ \$ 1.219 \text { per } \mathrm{ft}^{2} \\
\text { (quote from vendor) }\end{array}$ \\
\hline & - 16-oz Geotextile & $\$ 63,464$ & $\begin{array}{l}\text { Based on coverage of } 173,400 \mathrm{ft}^{2} @ \$ 0.366 \text { per } \mathrm{ft}^{2} \\
\text { (quote from vendor) }\end{array}$ \\
\hline & - Geocomposite & $\$ 8,369$ & $\begin{array}{l}\text { Based on coverage of } 11,100 \mathrm{ft}^{2} @ \$ 0.754 \text { per } \mathrm{ft}^{2} \\
\text { (quote from vendor) }\end{array}$ \\
\hline & - 3/4-inch Washed Rock & $\$ 32,256$ & $\begin{array}{l}\text { Based on } 2,240 \text { Ton } @ \$ 14.40 \text { per Ton (quote } \\
\text { from vendor for } 1600 \text { cubic yards) }\end{array}$ \\
\hline & - Sand & $\$ 11,592$ & $\begin{array}{l}\text { Based on } 1,120 \text { Ton @ } \$ 10.35 \text { per Ton (quote } \\
\text { from vendor for } 800 \text { cubic yards) }\end{array}$ \\
\hline & - Miscellaneous Consumables & $\$ 25,000$ & $\begin{array}{l}\text { Based on } \$ 500 \text { per day during construction period } \\
\text { of } 50 \text { days (water, fuel, mobile office rental, } \\
\text { storage rental) }\end{array}$ \\
\hline \multirow[t]{9}{*}{8} & \multicolumn{3}{|l|}{ Construction } \\
\hline & - Work Package & $\$ 20,000$ & $\begin{array}{l}2 \text { work packages ( } 1 \text { for dirt work and } 1 \text { for poly } \\
\text { spraying) @ } \$ 10 \mathrm{~K} \text { per package }\end{array}$ \\
\hline & - Construction Management & $\$ 90,000$ & $\begin{array}{l}\text { Based on } 90 \text { days @10 hours per day @ } \$ 100 \text { per } \\
\text { hour }\end{array}$ \\
\hline & - Construction Contractor & $\$ 324,000$ & $\begin{array}{l}4 \text { FTE's equivalent for procurement/QA/Project } \\
\text { Controls/FWS/PM }\end{array}$ \\
\hline & - Tank Farm Support Crew & $\$ 120,000$ & $\begin{array}{l}\text { Based on } 2 \text { HPT }+2 \text { IHT for } 50 \text { days @ } 10 \text { hours } \\
\text { per day }\end{array}$ \\
\hline & - Dirt Work (anchor trenches) & \$0 & $\begin{array}{l}\text { Cost for fill/grading @ } \$ 500 \text { per yard captures the } \\
\text { labor costs }\end{array}$ \\
\hline & - Geomembrane Installation & $\$ 150,000$ & $\begin{array}{l}\text { Based on crew of } 10 \text { for } 25 \text { days @ } 10 \text { hours per } \\
\text { day. Assuming } 1 \text { supervisor, } 4 \text { person crew, and } \\
5 \text { tank farm laborers. }\end{array}$ \\
\hline & - Gravel Cover Installation & $\$ 36,000$ & $\begin{array}{l}\text { Based on crew of } 6 \text { for } 10 \text { days @ } 10 \text { hours per } \\
\text { day. Assuming } 1 \text { supervisor, } 2 \text { person crew, and } \\
3 \text { tank farm laborers. }\end{array}$ \\
\hline & - Rental equipment - earth work & $\$ 120,000$ & ROM based on $\$ 4 \mathrm{~K}$ per day for equipment rental \\
\hline \multirow[t]{3}{*}{9} & \multicolumn{3}{|l|}{ Closeout } \\
\hline & - Clean up/Demobilize & $\$ 24,000$ & $\begin{array}{l}\text { Based on crew of } 8 \text { for five days. Labor at } \$ 60 \\
\text { per hour. }\end{array}$ \\
\hline & - Work Package Closeout & $\$ 12,000$ & \\
\hline
\end{tabular}


RPP-RPT-38323, Rev. 0

Table A-7. Gravel-covered Geomembrane Cost Estimate. (3 Sheets)

\begin{tabular}{|c|c|c|c|}
\hline \multicolumn{2}{|r|}{ Activity } & Estimated Cost & Basis \\
\hline & - Prepare Closeout Report & $\$ 12,000$ & \\
\hline & - Disposal & & TBD \\
\hline \multirow[t]{3}{*}{10} & \multicolumn{3}{|l|}{ Evaporation Pond } \\
\hline & - Construct Pond & $\$ 157,000$ & $\begin{array}{l}\text { Based on } 200 \text { feet } \times 200 \text { feet lined pond } 3 \text { feet } \\
\text { deep. Excavation } 14 \text { days } @ \$ 8 \mathrm{~K} \text { per day; liner } \\
\$ 35 \mathrm{~K} \text {; installation labor at } \$ 10 \mathrm{~K} \text {. }\end{array}$ \\
\hline & $\begin{array}{l}\text { Construct Drain from barrier to } \\
\text { evaporation pond }\end{array}$ & $\$ 22,250$ & $\begin{array}{l}\text { Based on } 250 \text { feet of buried culvert/PVC pipe for } \\
\text { conveying storm water from barrier to the } \\
\text { evaporation pond. } 7 \text { days to dig/backfill } @ \\
\$ 3 \mathrm{~K} \text { per day }+\$ 5 \text { per foot for pipe }\end{array}$ \\
\hline 11 & Maintenance & 0 & Required to meet design life of 25 years \\
\hline 12 & Subtotal & $\$ 3,020,250$ & \\
\hline 13 & Total & $\$ 3,900,325$ & Weather; uncertainties; contingency @30\% \\
\hline
\end{tabular}

Assumptions:

1. Work completed during fair season. 3. Training costs for construction forces not included.

2. Work is construction forces.

NOTE: This cost estimate was developed for relative comparison of other TY interim barrier alternatives.

\begin{tabular}{|c|c|c|c|c|c|}
\hline FTE & $=$ & Full-time equivalent & PNNL & $=$ & Pacific Northwest National Laboratory \\
\hline FWS & $=$ & Field Work Supervisor & PVC & $=$ & polyvinyl chloride \\
\hline HDPE & $=$ & high-density polyethylene & QA & $=$ & Quality Assurance \\
\hline HPT & $=$ & health physics technicians & ROM & $=$ & rough order of magnitude \\
\hline IHT & $=$ & industrial hygiene technicians & TBD & $=$ & to be determined \\
\hline NEPA & $=$ & National Environmental Policy Administration & TISB & $=$ & RPP-33431 \\
\hline NS\&L & $=$ & Nuclear Safety and Licensing & WRPS & $=$ & Washington River Protection Solutions LLC \\
\hline PM & $=$ & Project Management & & & \\
\hline
\end{tabular}

\section{A3.4 MODIFIED ASPHALT}

The modified asphalt interim surface barrier for deployment at TY farm selected for analysis was developed by Wilder Construction Company (Wilder). Wilder has developed the Modified Asphalt Technology for Waste Containment $\left(\mathrm{MatCon}^{\mathrm{TM}}\right)$ system, which is an advanced modified asphalt technology that combines Wilder's proprietary binder with, in most cases, standard asphalt aggregates used in high quality asphalt pavements. Modified asphalt barriers have been used to limit infiltration of precipitation at RCRA landfill sites.

The installation of MatCon is very similar to the installation of conventional asphalt. The hot MatCon binder is delivered in asphalt tanker trucks to the hot liquid storage tanks at the asphalt plant. Once the aggregates and the MatCon binder have been heated and mixed, the mixture will be deposited into conventional dump trucks. For installation in open areas, the MatCon will be hauled to the job site and dumped into a standard asphalt paver that lays the material on the prepared surface (see Figure A-23).

\footnotetext{
${ }^{\mathrm{m}}$ MatCon is a trademark of the Wilder Construction Company.
} 
Figure A-23. Standard MatCon ${ }^{\mathrm{TM}}$ Installation.

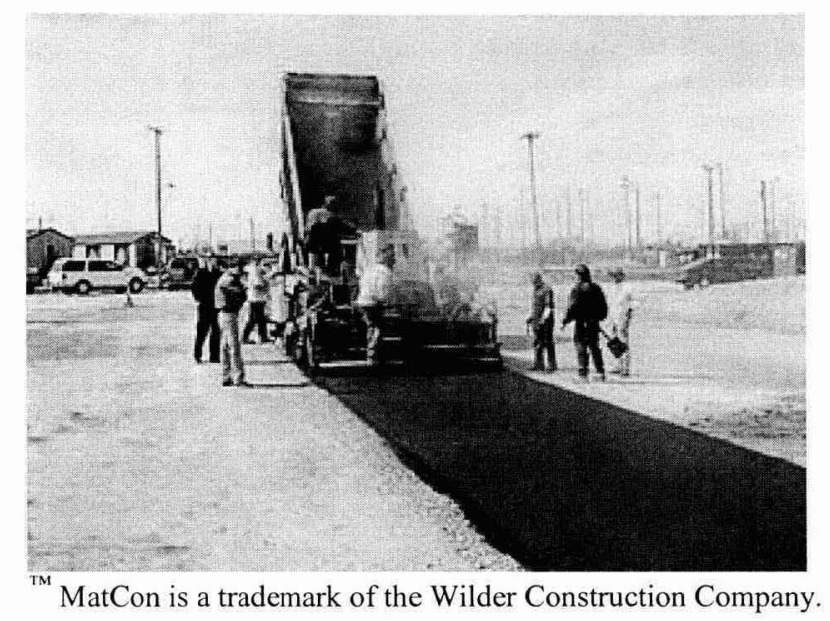

MatCon dense or open-graded layers are normally placed 4 inches in depth. Once the MatCon is laid by the paver, rolling will immediately begin using a vibratory or rubber-tired roller until the desired density is achieved. If open-graded MatCon is being placed, the compaction will be limited to two non-vibratory passes with a steel roller. If heavy continuous traffic over a section of the MatCon is required, an additional 4-inch layer ( 8 inches total) should be considered for those areas.

The construction of dense graded MatCon requires the elimination of nearly all cold joints. This is accomplished by keeping the pavement panels short enough that when the paver is set back to start another panel, the joint being placed against is still hot and not yet compacted. Once placement has started of the adjacent panel, the hot joint between the two panels can be compacted, which results in a seamless connection. When a prolonged break is anticipated, such as the end of a work shift, MatCon has developed a method for cold joint preparation. Prior to placing the overlay panel, a tack coat is required to be applied to the existing MatCon. The overlay panel will be laid 1 foot wider than the cold joint panel. A diagram of the cold joint is presented in Figure A-24.

Figure A-24. MatCon ${ }^{\mathrm{TM}}$ Cold Joint Preparation.

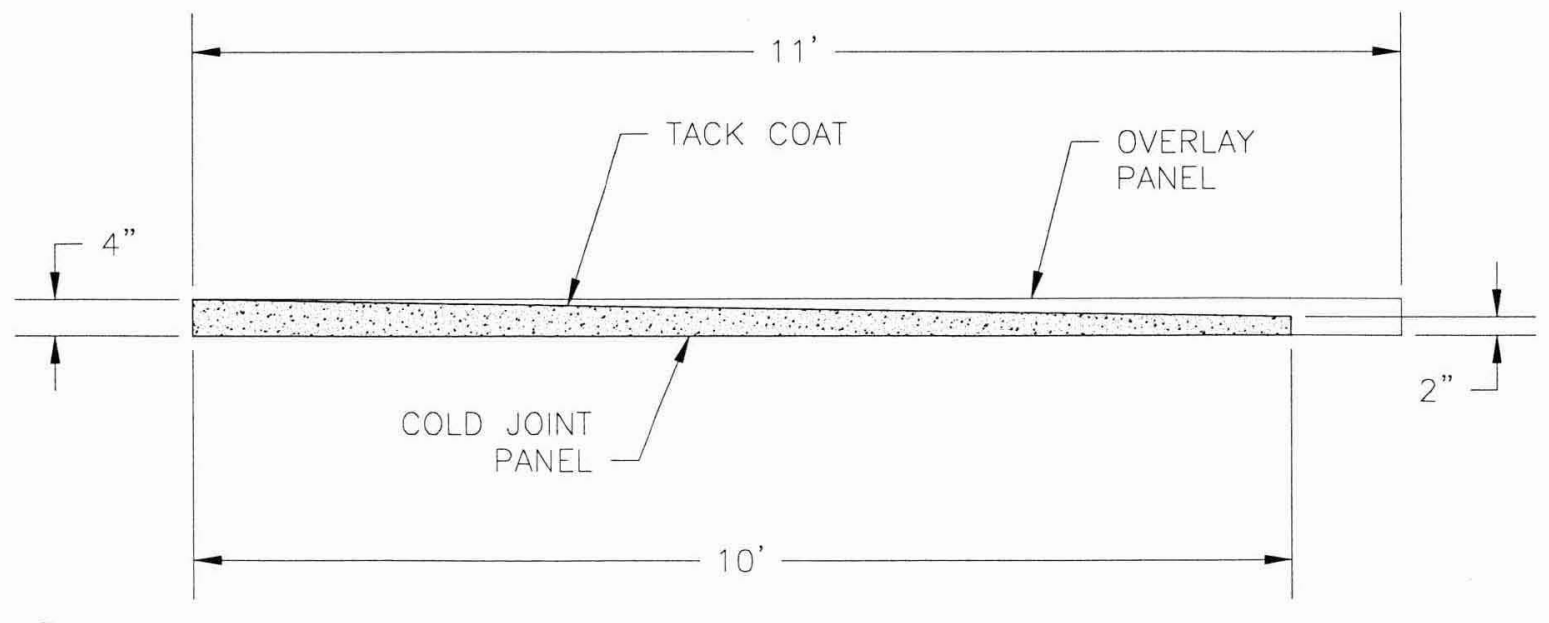

${ }^{\mathrm{TM}}$ MatCon is a trademark of Wilder Construction Company. 
For installation of the MatCon in congested areas, a loader or transfer device would be utilized for the placement. The MatCon would be spread manually and compacted with a plate whacker. Interfaces between the MatCon and above-grade interferences would be constructed by sloping the MatCon away from the interface or by installing commercially available asphalt-coated substrate around the interface to form a flashing around the penetration. An example equipment interface utilizing the slope methodology is presented in Figure A-25.

The modified asphalt option will require some cut and fill excavation work to slope the surface allowing water to naturally flow to a desired location. The excavation work will require the use of heavy equipment where possible, with the majority of grading performed by hand.

Maintenance of the modified asphalt concept for cracks can be performed by installing a high quality commercially available crack sealer. The crack sealer would have to be installed by a qualified repair contractor.

Figure A-25. Example Equipment Interface Detail.

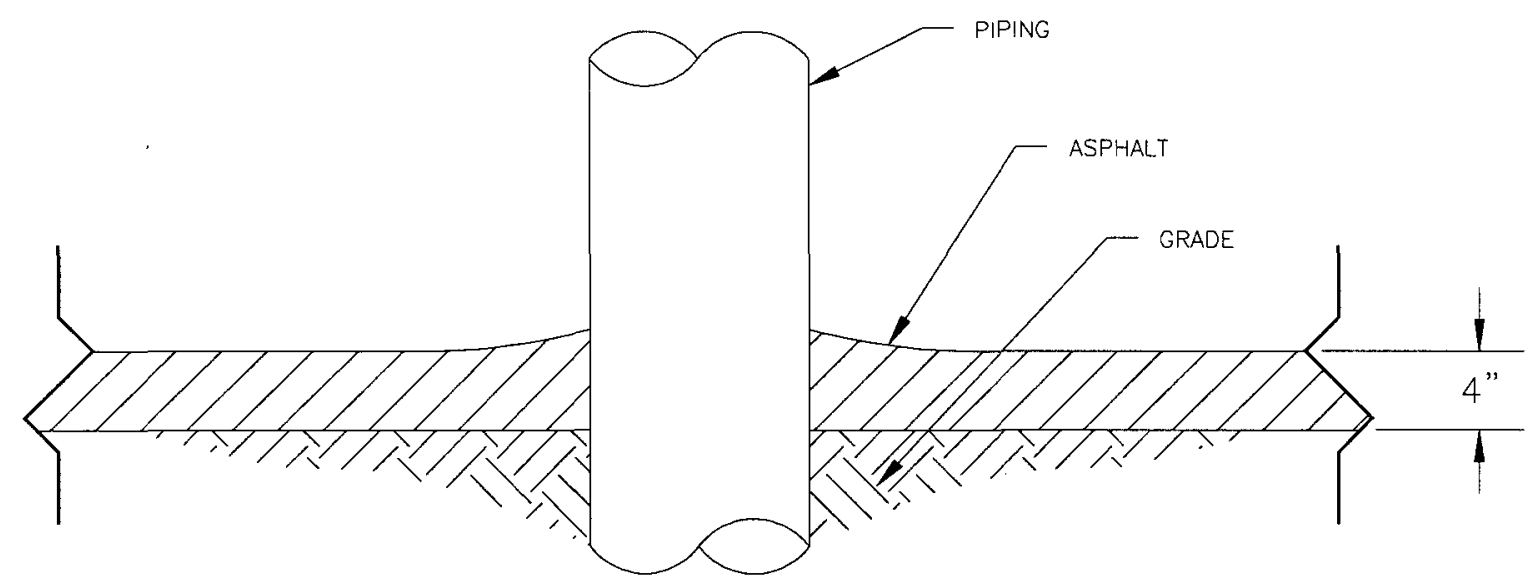

\section{A3.4.1 Required Material and Equipment}

The following material and equipment would be required for production, delivery, and installation of a modified asphalt barrier at TY farm.

- $\quad$ Asphalt batch plant (via contract with asphalt vendor)

- $\quad$ Asphalt aggregates (via contract with asphalt vendor)

- MatCon binder (Wilder)

- Dump trucks (via contract with asphalt vendor)

- $\quad$ Asphalt paver (via contract with asphalt vendor)

- Vibratory or rubber-tired roller (via contract with asphalt vendor)

- Tack coat material for cold joints

- Front loader (installation in congested areas)

- Hand/plate compactor (installation in congested areas). 


\section{A3.4.2 Subgrade Requirements}

The TY farm surface must be graded and prepped for application of the modified asphalt. The existing surface of the 241-TY tank farm is generally sloped from east to west. The final cut and fill plan for the barrier surface needs to be defined to reflect the best balance between the existing surface (i.e., cut volume) and placement of new fill material. For the purpose of this evaluation, it is assumed that a constant 0.8 -percent slope will be necessary to facilitate precipitation runoff. Based on an analysis of the existing topographical information, a constant 0.8-percent slope can be established over the assumed barrier footprint by:

- $\quad$ Removing the existing pipeline berm (approximately 70 cubic yards) and using this material to fill in low spots

- $\quad$ Grading the farm to move approximately 230 cubic yards of material

- $\quad$ Adding approximately 430 cubic yards of new fill material.

One option identified during the value engineering sessions was to relax the slope requirements for the interim barrier. For the TY farm interim barrier this could be accomplished by removing the pipeline berm and using the spoils to fill in low spots within the farm. This option would result in localized pooling of water, with general drainage off of the western edge of the barrier footprint. This would limit the amount of additional fill material that would need to be brought into the farm.

Once the surface grade is established, the subgrade should be compacted in accordance with design specifications, and at a minimum compacted to a level that allows construction and deployment equipment traffic without causing ruts or surface deformation. To achieve proper compaction an additional 2 inches of $5 / 8$ minus is assumed to be required over the existing gravel surface to provide a base for the modified asphalt installation. The final grade should be graded and compacted to support the asphalt equipment.

\section{A3.4.3 Anchorage Requirements}

No anchorage to prevent uplift from wind is required for the modified asphalt concept.

\section{A3.4.4 Schedule}

Major schedule elements associated with constructing the modified asphalt barrier include:

- $\quad$ Site preparation: 20 days (4 weeks) duration assumed based on site preparation requirements at $\mathrm{T}$ farm.

- $\quad$ Asphalt placement: 15 days (3 weeks) duration. Estimates from the vendor (Wilder) indicated that they performed a 2.35 -acre project in one shift (10 hours). This estimate was based on no interferences within the barrier footprint, the asphalt plant was located one mile from the project site, and no work restrictions were imposed during the work activity. Based on current work restrictions on site, a conservative time-frame to construct the asphalt barrier is assumed at 15 days to provide time for placement and compaction of material around penetrations. 
Based on temperature requirements for the modified asphalt during the installation process and the drive time required to get to the site, the vendor recommended installing the barrier at temperatures of 60 degrees Fahrenheit or higher. Higher ambient temperatures increase the working life and compact ability of the material.

\section{A3.4.5 Design Issues and Concerns}

The modified asphalt concept has the following design issues and concerns:

- $\quad$ The subsystem specification (RPP-SPEC-38937) requires a minimum design life of 25 years. The first MatCon barrier was installed in Ferndale, Washington in 1989. To date, the barrier installed in Ferndale has not cracked and has not required any maintenance despite the use of heavy equipment on its surface.

- Installation in congested areas where the paver and dump truck cannot reach would have to be determined during the design process.

- Interface details with existing above-grade equipment would have to be determined during the design process.

- $\quad$ Compaction requirements would need to be determined during the design process. During the compaction of the subgrade for the $\mathrm{T}$ farm surface barrier, the vibratory function of the roller had to be disabled.

- The installation of the modified asphalt barrier would require the use of contractorprovided equipment (paver, dump trucks, etc). Using the contractor-provided equipment runs the risk of having to buy the equipment if it gets contaminated.

- Actual binder content would need to be determined during the design phase of the project. The higher binder would require lighter equipment to achieve the desired compaction. In addition, the higher binder content would result in a softer material that would be less susceptible to cracking. The cost of the binder increases approximately 13 percent for each 1-percent increase. The vendor estimated an increase of no more than 1 to 2 percent would be required.

\section{A3.4.6 Standard Crew Size to Construct}

The estimated crew size required for construction of the modified asphalt barrier consists of a crew of approximately 17. This includes:

- 1 asphalt contractor crew of approximately 8

- 4 additional laborers for installation support

- 2 HPTs

- 2 IHTs

- 1 construction superintendent.

\section{A3.4.7 Modified Asphalt Barrier Cost Estimate}

The rough cost estimate for the modified asphalt barrier is provided in Table A-8. 
Table A-8. Modified Asphalt Barrier Cost Estimate. (3 Sheets)

\begin{tabular}{|c|c|c|c|}
\hline \multicolumn{2}{|r|}{ Activity } & \multirow{2}{*}{$\frac{\text { Estimated Cost }}{\$ 180,000}$} & \multirow{2}{*}{$\begin{array}{l}\text { Basis } \\
\text { T farm labor charges, 1 FTE equivalent } \\
\text { (engineering, QA, Safety, Management) for } \\
1 \text { year. Support dependent on duration and } \\
\text { scalable by footprint area. }\end{array}$} \\
\hline 1 & WRPS Labor & & \\
\hline \multirow[t]{8}{*}{2} & \multicolumn{3}{|l|}{ Field Work Support } \\
\hline & - Interim Covering Monitoring & $\$ 141,200$ & $\begin{array}{l}\text { T Farm Barrier Actuals at } \$ 141 \mathrm{~K} \text { for PNNL } \\
\text { contract, assume } 1 / 2 \mathrm{~T} \text { costs for TY Monitoring } \\
\text { Plan }\end{array}$ \\
\hline & - Ground Scan & $\$ 26,500$ & $\begin{array}{l}\text { T Farm Barrier Actuals } \$ 21.5 \mathrm{~K} \text {, assume an } \\
\text { additional } \$ 5 \mathrm{~K} \text { for TY barrier for additional } \\
\text { anchor trenches }\end{array}$ \\
\hline & - Dome Deflection Surveys & $\$ 9,800$ & $\begin{array}{l}\text { T Farm Barrier Actuals, assume same costs for } \\
\text { TY barrier. May be reduced based on reduced } \\
\text { frequency of scans. }\end{array}$ \\
\hline & - Survey Services & $\$ 19,000$ & T Farm Barrier Costs, assume same costs for TY \\
\hline & - TY Barrier NEPA / CX & $\$ 13,200$ & T Farm Barrier Costs, assume same costs for TY \\
\hline & - TY Farm Vadose Monitoring & $\$ 223,400$ & $\begin{array}{l}\text { T Farm Barrier Actuals PNNL contract for } \\
\text { monitoring system design, assume } 100 \mathrm{~K} \text { for TY } \\
\text { except as noted based on the monitoring design } \\
\text { being a modification to the T barrier design. Note } \\
\text { monitoring system requirements are TBD. }\end{array}$ \\
\hline & - Direct Push / Field Crew / Lab & $\$ 300,200$ & $\begin{array}{l}\text { T Farm Barrier Actuals for direct push crew } \\
\text { (monitoring system installation), assume same } \\
\text { costs for TY barrier }\end{array}$ \\
\hline 3 & \multicolumn{3}{|l|}{ Design } \\
\hline & - Design Package & $\$ 250,000$ & $\begin{array}{l}\text { Cost estimate for completion of interim barrier } \\
\text { design }\end{array}$ \\
\hline 4 & NS\&L & $\$ 0$ & No NS\&L action required \\
\hline 5 & RadCon & $\$ 7,200$ & $\begin{array}{l}\text { Assume } 3 \text { weeks for generation of release plan for } \\
\text { vendor equipment in farm }\end{array}$ \\
\hline \multirow[t]{4}{*}{6} & \multicolumn{3}{|l|}{ Surface Preparation } \\
\hline & - Dirt work & & \\
\hline & - Cut & $\$ 150,000$ & $\begin{array}{l}\text { Based on re-grading approximately } 330 \text { yards of } \\
\text { gravel }\end{array}$ \\
\hline & - Fill/compaction/grading & $\$ 217,500$ & $\begin{array}{l}\text { Approximately } 430 \text { yards fill required to achieve } \\
\text { slope. Assume } 5 / 8 \text { minus delivered from } \\
\text { American rock used for fill. Based on TISB } \\
3,000 \text { cubic yards of fill placed and compacted for } \\
\$ 1.5 \text { million. This is approximately } \$ 500 \text { per yard } \\
\text { for compacted fill in farm with grading }\end{array}$ \\
\hline
\end{tabular}


Table A-8. Modified Asphalt Barrier Cost Estimate. (3 Sheets)

\begin{tabular}{|c|c|c|c|}
\hline \multicolumn{2}{|r|}{ Activity } & \multirow{2}{*}{$\frac{\text { Estimated Cost }}{\$ 57,500}$} & \multirow[b]{2}{*}{$\begin{array}{l}\text { Basis } \\
\text { Assume } 2 \text { inches } 5 / 8 \text { minus compacted base for } \\
\text { installation of asphalt. } 550 \text { cubic yards of material } \\
\text { required to achieve } 2 \text {-inch depth }(86,200 \text { square } \\
\text { feet). } 435 \text { yards placed to achieve slope so } \\
\text { remaining } 115 \text { yards required to achieve } 2 \text {-inch } \\
\text { base. Based on TISB } 3,000 \text { cubic yards of clean } \\
\text { fill placed and compacted for } \$ 1.5 \text { million. This is } \\
\text { approximately } \$ 500 \text { per yard for compacted fill in } \\
\text { the farm with grading. }\end{array}$} \\
\hline & - Install Riser extensions/vaults & & \\
\hline & - Equipment Rental & $\$ 0$ & $\begin{array}{l}\text { Assume installation is included in the grading/fill } \\
\text { costs }\end{array}$ \\
\hline \multirow[t]{6}{*}{7} & \multicolumn{3}{|l|}{ Material Procurement } \\
\hline & - Fill material & $\$ 11,550$ & $\begin{array}{l}\text { Assume } 550 \text { cubic yards of } 5 / 8 \text { minus required for } \\
2 \text {-inch base. Rough estimate from American } \\
\text { Rock Products of } \$ 21 \text { per cubic yard delivered to } \\
200 W \text { area. }\end{array}$ \\
\hline & - Matcon Binder & $\$ 360,000$ & $\begin{array}{l}\text { Based on e-mail from Jerry Thayer (Wilder } \\
\text { Construction Company) at } \$ 180,000 \text { per acre for } \\
\text { the Matcon Binder }\end{array}$ \\
\hline & - Hot Mix Asphalt & $\$ 120,000$ & $\begin{array}{l}\text { Based on e-mail from Jerry Thayer (Wilder } \\
\text { Construction Company) at } \$ 60,000 \text { per acre which } \\
\text { includes production, haul, and laydown. }\end{array}$ \\
\hline & - Riser extensions/vaults & $\$ 40,000$ & $\begin{array}{l}\text { Based on } 60 \text { concrete utility vaults plus } \$ 10,000 \\
\text { for corrugated pipe/PVC pipe plus caps }\end{array}$ \\
\hline & - Miscellaneous Consumables & $\$ 17,500$ & $\begin{array}{l}\text { Assume } \$ 500 \text { per day during construction (water, } \\
\text { fuel, mobile office rental, storage rental) }\end{array}$ \\
\hline \multirow[t]{2}{*}{8} & \multicolumn{3}{|l|}{ Construction } \\
\hline & - Work Package & $\$ 20,000$ & $\begin{array}{l}2 \text { work packages ( } 1 \text { for dirt work and } 1 \text { for poly } \\
\text { spraying)@ } \$ 10 \mathrm{~K} \text { per package }\end{array}$ \\
\hline & - Construction Management & $\$ 75,000$ & $\begin{array}{l}\text { TISB } ~ \$ 380 \mathrm{~K} \text { actual; } 0 \text { in original estimate - } \\
\text { based on } 75 \text { days @ } 10 \text { hours per day @ } \$ 100 \text { per } \\
\text { hour. Assumed } 40 \text { days for up front planning and } \\
\text { design support, } 20 \text { days for grading, and } 15 \text { days } \\
\text { for barrier install }\end{array}$ \\
\hline & - Construction Contractor & $\$ 126,000$ & $\begin{array}{l}4 \text { FTE's equivalent for procurement/QA/Project } \\
\text { Controls/FWS/PM }\end{array}$ \\
\hline & - Tank Farm Support Crew & $\$ 84,000$ & $\begin{array}{l}\text { Based on } 2 \mathrm{HPT}+2 \text { IHT for } 35 \text { days @ } \$ 60 \text { per } \\
\text { hour. Assumed } 20 \text { days for grading and } 15 \text { days } \\
\text { for barrier install }\end{array}$ \\
\hline & - Dirt Work & $\$ 0$ & $\begin{array}{l}\text { Cost for fill/grading @ } 500 \text { per yard captures the } \\
\text { labor costs }\end{array}$ \\
\hline & $\begin{array}{l}\text { - Asphalt Laydown Tank Farm } \\
\text { Support }\end{array}$ & $\$ 36,000$ & $\begin{array}{l}\text { Assume } 4 \text { laborers for } 15 \text { days @ } \$ 60 \text { per hour for } \\
\text { installation support. Assumed } 15 \text { days for barrier } \\
\text { install }\end{array}$ \\
\hline
\end{tabular}


Table A-8. Modified Asphalt Barrier Cost Estimate. (3 Sheets)

\begin{tabular}{|c|c|c|c|}
\hline \multicolumn{2}{|r|}{ Activity } & \multirow{2}{*}{$\frac{\text { Estimated Cost }}{\$ 54,000}$} & \multirow{2}{*}{$\begin{array}{l}\text { Basis } \\
\text { Assume } 2 \text { technical representatives @ } \$ 3600 \text { per } \\
\text { day for } 15 \text { days. Includes travel, hourly rate, and } \\
\text { per diem. Assumed } 15 \text { days for barrier install. }\end{array}$} \\
\hline & $\begin{array}{l}\text { - Vendor Technical } \\
\text { Representatives }\end{array}$ & & \\
\hline & - Equipment Rental & $\$ 80,000$ & $\begin{array}{l}\text { ROM based on } \$ 4 \mathrm{~K} \text { per day for equipment. Only } \\
\text { required for grading leveling effort @ } 20 \text { days. } \\
\text { Asphalt estimate includes equipment for } \\
\text { delivery/placement/rolling asphalt. }\end{array}$ \\
\hline \multirow[t]{5}{*}{9} & \multicolumn{3}{|l|}{ Closeout } \\
\hline & - Clean up/Demobilize & $\$ 24,000$ & $\begin{array}{l}\text { Based on crew of } 8 \text { for five days. Labor at } \$ 60 \\
\text { per hour. }\end{array}$ \\
\hline & - Work Package Closeout & $\$ 12,000$ & \\
\hline & - Prepare Closeout Report & $\$ 12,000$ & \\
\hline & - Disposal & $\$ 5,000$ & Disposal ROM \\
\hline \multirow[t]{3}{*}{10} & \multicolumn{3}{|l|}{ Evaporation Pond } \\
\hline & Construct Pond & $\$ 157,000$ & $\begin{array}{l}\text { Based on } 200 \text { feet } \times 200 \text { feet lined pond } 3 \text { feet } \\
\text { deep. Excavation } 14 \text { days } @ \$ 8 \mathrm{~K} \text { per day; liner } \\
\$ 35 \mathrm{~K} \text {; installation labor at } \$ 10 \mathrm{~K} \text {. }\end{array}$ \\
\hline & $\begin{array}{l}\text { Construct Drain from barrier to } \\
\text { evaporation pond }\end{array}$ & $\$ 22,250$ & $\begin{array}{l}\text { Based on } 250 \text { feet of buried culvert/PVC pipe for } \\
\text { conveying storm water from barrier to the } \\
\text { evaporation pond. } 7 \text { days to dig/backfill @ } \\
\$ 3 \mathrm{~K} \text { per day }+\$ 5 \text { per foot for pipe. }\end{array}$ \\
\hline 11 & Maintenance & 0 & Required to meet design life of 25 years \\
\hline 12 & Subtotal & $\$ 3,156,300$ & \\
\hline 13 & Total & $\$ 4,103,190$ & Weather; uncertainties; contingency @ 30\% \\
\hline
\end{tabular}

Assumptions:

1. Work completed during fair season.

2. Work is vendor provided plus construction forces support.

3. Training costs for construction forces not included.

4. Duration of 20 days for grading and 15 days for asphalt placement.

NOTE: This cost estimate was developed for relative comparison of other TY interim barrier alternatives.

\begin{tabular}{|c|c|c|c|c|c|}
\hline FTE & $=$ & Full-time equivalent & PNNL & $=$ & Pacific Northwest National Laboratory \\
\hline FWS & $=$ & Field Work Supervisor & PVC & $=$ & polyvinyl chloride \\
\hline HPT & $=$ & health physics technicians & QA & $=$ & Quality Assurance \\
\hline IHT & $=$ & industrial hygiene technicians & ROM & $=$ & rough order of magnitude \\
\hline NEPA & $=$ & National Environmental Policy Administration & TBD & $=$ & to be determined \\
\hline NS\&L & $=$ & Nuclear Safety and Licensing & TISB & $=$ & RPP-33431 \\
\hline PM & $=$ & Project Management & WRPS & $=$ & Washington River Protection Solutions LLC \\
\hline
\end{tabular}




\section{A4.0 RESULTS}

Results from application of the scoring system described in Section 3.1 to the options described in Section A3.0 are presented in the following sections. The materials/options were evaluated and scored in a meeting held on March 18, 2009. Attendees included representatives from the DOE, Office of River Protection, Washington State Department of Ecology, WRPS, and Columbia Energy \& Environmental Services, Inc.

\section{A4.1 SPRAY-ON POLYUREA}

Table A-9 summarizes the scoring results for the spray-on polyurea surface barrier.

Table A-9. Spray-on Polyurea Score.

\begin{tabular}{|l|c|c|c|}
\hline \multicolumn{1}{|c|}{ Criterion } & $\begin{array}{c}\text { Importance } \\
\text { (I) }\end{array}$ & $\begin{array}{c}\text { Performance } \\
(\mathbf{P})\end{array}$ & $\begin{array}{c}\text { Score } \\
(\mathbf{S}=\mathbf{I} \text { * } \mathbf{P})\end{array}$ \\
\hline Total cost & 3 & 5 & 15 \\
\hline Environmental conditions & 2 & 8 & 14 \\
\hline Flexibility and expansion & 1 & 8 & 7 \\
\hline Dome loading & 3 & 5 & 15 \\
\hline Tank farm facility surveillance and monitoring & 3 & 5 & 15 \\
\hline Safety issues during construction & 3 & 4 & 12 \\
\hline Retrieval & 2 & 8 & 16 \\
\hline Interim barrier monitoring & 2 & 8 & 16 \\
\hline Future removal if required (closure) & 3 & 5 & 15 \\
\hline $\begin{array}{l}\text { Impact on potential future tank farm soil } \\
\text { investigation }\end{array}$ & 2 & 5 & 10 \\
\hline Applicability at other tank farms & 2 & 7 & 14 \\
\hline Total & & & 149 \\
\hline
\end{tabular}

\section{A4.2 SPRAY-ON POLYUREA WITH GRAVEL COVER}

Table A-10 summarizes the scoring results for the spray-on polyurea surface barrier with gravel.

Table A-10. Spray-on Polyurea with Gravel Cover Score. (2 Sheets)

\begin{tabular}{|l|c|c|c|}
\hline \multicolumn{1}{|c|}{ Criterion } & $\begin{array}{c}\text { Importance } \\
\text { (I) }\end{array}$ & $\begin{array}{c}\text { Performance } \\
\mathbf{( P )}\end{array}$ & $\begin{array}{c}\text { Score } \\
(\mathbf{S}=\mathbf{I} \text { * P) }\end{array}$ \\
\hline Total cost & 3 & 4 & 12 \\
\hline Environmental conditions & 2 & 10 & 20 \\
\hline Flexibility and expansion & 1 & 7 & 7 \\
\hline Dome loading & 3 & 3 & 9 \\
\hline
\end{tabular}


Table A-10. Spray-on Polyurea with Gravel Cover Score. (2 Sheets)

\begin{tabular}{|l|c|c|c|}
\hline \multicolumn{1}{|c|}{ Criterion } & $\begin{array}{c}\text { Importance } \\
\text { (I) }\end{array}$ & $\begin{array}{c}\text { Performance } \\
\text { (P) }\end{array}$ & $\begin{array}{c}\text { Score } \\
(\mathbf{S}=\mathbf{I} \text { * P) }\end{array}$ \\
\hline Tank farm facility surveillance and monitoring & 3 & 6 & 18 \\
\hline Safety issues during construction & 3 & 4 & 12 \\
\hline Retrieval & 2 & 7 & 14 \\
\hline Interim barrier monitoring & 2 & 2 & 4 \\
\hline Future removal if required (closure) & 3 & 4 & 12 \\
\hline $\begin{array}{l}\text { Impact on potential future tank farm soil } \\
\text { investigation }\end{array}$ & 2 & 4 & 8 \\
\hline Applicability at other tank farms & 2 & 7 & 14 \\
\hline Total & & & 130 \\
\hline
\end{tabular}

\section{A4.3 ROOFED STRUCTURE}

Table A-11 summarizes the scoring results for the fabric-covered structure.

Table A-11. Fabric-covered Structure Score.

\begin{tabular}{|l|c|c|c|}
\hline \multicolumn{1}{|c|}{ Criterion } & $\begin{array}{c}\text { Importance } \\
\text { (I) }\end{array}$ & $\begin{array}{c}\text { Performance } \\
\text { (P) }\end{array}$ & $\begin{array}{c}\text { Score } \\
\text { (S=I* P) }\end{array}$ \\
\hline Total cost & 3 & 1 & 3 \\
\hline Environmental conditions & 2 & 2 & 4 \\
\hline Flexibility and expansion & 1 & 2 & 2 \\
\hline Dome loading & 3 & 10 & 30 \\
\hline Tank farm facility surveillance and monitoring & 3 & 6 & 18 \\
\hline Safety issues during construction & 3 & 5 & 15 \\
\hline Retrieval & 2 & 2 & 12 \\
\hline Interim barrier monitoring & 2 & 10 & 20 \\
\hline Future removal if required (closure) & 3 & 2 & 6 \\
\hline $\begin{array}{l}\text { Impact on potential future tank farm soil } \\
\text { investigation }\end{array}$ & 2 & 8 & 16 \\
\hline Applicability at other tank farms & 2 & 2 & 4 \\
\hline Total & & & 130 \\
\hline
\end{tabular}

\section{A4.4 GEOMEMBRANE}

Table A-12 summarizes the scoring results for the geomembrane barrier. 
Table A-12. Geomembrane Score.

\begin{tabular}{|l|c|c|c|}
\hline \multicolumn{1}{|c|}{ Criterion } & $\begin{array}{c}\text { Importance } \\
\text { (I) }\end{array}$ & $\begin{array}{c}\text { Performance } \\
\text { (P) }\end{array}$ & $\begin{array}{c}\text { Score } \\
(\mathbf{S}=\mathbf{I} \text { * P) }\end{array}$ \\
\hline Total cost & 3 & 10 & 30 \\
\hline Environmental conditions & 2 & 7 & 14 \\
\hline Flexibility and expansion & 1 & 7 & 7 \\
\hline Dome loading & 3 & 5 & 15 \\
\hline Tank farm facility surveillance and monitoring & 3 & 5 & 15 \\
\hline Safety issues during construction & 3 & 6 & 18 \\
\hline Retrieval & 2 & 4 & 8 \\
\hline Interim barrier monitoring & 2 & 9 & 18 \\
\hline Future removal if required (closure) & 3 & 5 & 15 \\
\hline $\begin{array}{l}\text { Impact on potential future tank farm soil } \\
\text { investigation }\end{array}$ & 2 & 5 & 10 \\
\hline Applicability at other tank f arms & 2 & 4 & 8 \\
\hline Total & & & 158 \\
\hline
\end{tabular}

\section{A4.5 GEOMEMBRANE COVERED WITH GRAVEL}

Table A-13 summarizes the scoring results for the geomembrane covered with gravel.

Table A-13. Geomembrane Covered with Gravel Score.

\begin{tabular}{|l|c|c|c|}
\hline \multicolumn{1}{|c|}{ Criterion } & $\begin{array}{c}\text { Importance } \\
\text { (I) }\end{array}$ & $\begin{array}{c}\text { Performance } \\
\text { (P) }\end{array}$ & $\begin{array}{c}\text { Score } \\
(\mathbf{S}=\mathbf{I} \text { * P) }\end{array}$ \\
\hline Total cost & 3 & 9 & 27 \\
\hline Environmental conditions & 2 & 10 & 20 \\
\hline Flexibility and expansion & 1 & 7 & 7 \\
\hline Dome loading & 3 & 3 & 9 \\
\hline Tank farm facility surveillance and monitoring & 3 & 6 & 18 \\
\hline Safety issues during construction & 3 & 6 & 18 \\
\hline Retrieval & 2 & 4 & 8 \\
\hline Interim barrier monitoring & 2 & 2 & 4 \\
\hline Future removal if required (closure) & 3 & 4 & 12 \\
\hline $\begin{array}{l}\text { Impact on potential future tank farm soil } \\
\text { investigation }\end{array}$ & 2 & 4 & 8 \\
\hline Applicability at other tank farms & 2 & 4 & 8 \\
\hline Total & \multicolumn{3}{|l}{} \\
\hline
\end{tabular}




\section{A4.6 MODIFIED ASPHALT}

Table A-14 summarizes the scoring results for the modified asphalt barrier.

Table A-14. Modified Asphalt Score.

\begin{tabular}{|l|c|c|c|}
\hline \multicolumn{1}{|c|}{ Criterion } & $\begin{array}{c}\text { Importance } \\
\text { (I) }\end{array}$ & $\begin{array}{c}\text { Performance } \\
\text { (P) }\end{array}$ & $\begin{array}{c}\text { Score } \\
(\mathbf{S}=\mathbf{I} \text { * P) }\end{array}$ \\
\hline Total cost & 3 & 8 & 24 \\
\hline Environmental conditions & 2 & 8 & 16 \\
\hline Flexibility and expansion & 1 & 7 & 7 \\
\hline Dome loading & 3 & 4 & 12 \\
\hline Tank farm facility surveillance and monitoring & 3 & 8 & 24 \\
\hline Safety issues during construction & 3 & 7 & 21 \\
\hline Retrieval & 2 & 7 & 14 \\
\hline Interim barrier monitoring & 2 & 8 & 16 \\
\hline Future removal if required (closure) & 3 & 8 & 24 \\
\hline $\begin{array}{l}\text { Impact on potential future tank farm soil } \\
\text { investigation }\end{array}$ & 2 & 5 & 10 \\
\hline Applicability at other tank $\mathrm{f}$ arms & 2 & 3 & 6 \\
\hline Total & & & 174 \\
\hline
\end{tabular}

\section{A5.0 CONCLUSIONS AND RECOMMENDATIONS}

Based on the material evaluation performed, the modified asphalt material offers a number of advantages over other interim barrier materials that were evaluated. The modified asphalt barrier material is recommended for use as the interim barrier material at the TY tank farm.

\section{A6.0 RUNOFF ALTERNATIVES}

Potential alternatives for managing and disposing of the runoff from interim surface barriers are identified in Section 5.0. An initial screening of the alternatives is provided in the following sections.

\section{A6.1 INFILTRATION POND}

Given the topography of the TY farm and surrounding area an infiltration pond could be sited to the west/northwest of the tank farm. The pond would be sized to handle the design storm event and would have a capacity of approximately 72,000 gallons. This option would result in enhanced recharge near the tank farm. Due to the uncertainties associated with geology beneath 
the tank farms and the potential for the enhanced recharge to mobilize contamination this option is eliminated from consideration for the TY farm interim barrier design.

\section{A6.2 COLLECTION AND EVAPORATION POND}

A lined evaporation pond could be constructed to the west of the TY farm. Based on the size of the TY interim barrier, an infiltration pond would need to have a foot print of approximately 100 feet $\times 220$ feet and would likely have standing water present in the pond over a good part of the year. Having an evaporation pond with standing water present brings a host of monitoring, maintenance, and surveillance activities. Issues associated with mosquito control, tumbleweed removal, wildlife, along with the potential for blow sand to accumulate in the pond were raised during the investigation of this alternative. Based on these issues, this alternative is eliminated from consideration for the TY farm interim barrier design.

\section{A6.3 COLLECTION AND STORM WATER DISCHARGE SYSTEM}

This option is functionally equivalent to the infiltration pond but offers the advantage of eliminating the open pond structure. The storm water discharge system would consist of an engineered drainage and discharge field (i.e., perforated pipe similar to a septic system). This option would eliminate some of the operations/maintenance issues associated with the infiltration pond design but would still be discharging the runoff to the soil near the tank farm. Because of the uncertainties associated with geology beneath the tank farms and the potential for the enhanced recharge to mobilize contamination, this option is eliminated from consideration for the TY farm interim barrier design.

\section{A6.4 STORAGE AND EVAPORATION}

This option involves constructing an evaporative barrier or an evapo-transpiration barrier in the area to the west of the TY farm. Runoff from the TY interim surface barrier would be collected and routed to a lined evaporation basin where it would be distributed into the soil layer. The soil layer would be used to store the water until it is evaporated. With a lined basin none of the runoff would be discharged to the soil column and the precipitation that falls on the evaporative basin would be captured for subsequent evaporation. This would reduce the net recharge in the area surrounding the tank farm. Based on initial sizing, the footprint of the evaporative basin would need to be approximately 200 feet by $200 \mathrm{feet}$. With this option, the soil excavated could be replaced after the liner is installed eliminated any excess spoils. Once in place, this system would be passively operated, would not involve any operating expense, and would involve minimal maintenance.

The soil in the evaporative basin area could be vegetated or un-vegetated. In order to take advantage of plant transpiration native vegetation could be established. If the objective were to prevent any vegetation on the evaporative barrier, then a layer of gravel would be necessary to minimize wind erosion and active maintenance would be required to control plant growth. 


\section{A6.5 STORAGE AND REMOVAL}

This option would involve construction of a storm water retention pond either inside or outside the tank farm to collect runoff until it could be removed. This option could be configured similar to the evaporative pond alternative if the pond were lined. A permanent or portable pump transfer line system could be installed to transfer water from the retention pond to a tanker truck for transporting the water to an onsite facility such as the Effluent Treatment Facility.

This option has the advantage of not discharging water to the soil. The disadvantage is that the retention facility would require monitoring and the transfer equipment would need to be designed to operate in the winter months and maintained to ensure operability. There is also a potential requirement that the runoff water would require sampling and analysis on a batch by batch basis before it is transported to the Effluent Treatment Facility.

\section{A6.6 RECOMMENDATION}

Of the options evaluated for managing and disposal of the runoff from the TY farm interim surface barrier, the storage and evaporation option consisting of a lined evaporation basin configured as an evapo-transpiration system meets the objective of eliminating the water discharge to the subsurface in the area surrounding the tank farm with minimal maintenance and operating requirements. The storage and evaporation option is recommend for the TY farm interim surface barrier application.

\section{A7.0 REFERENCES}

HNF-EP-0182, 2008, Waste Tank Summary Report for Month Ending October 31, 2008, Rev. 247, Washington River Protection Solutions LLC, Richland, Washington.

RPP-33431, 2008, Design Analysis for T-Farm Interim Surface Barrier (TISB), Revision 0A, Washington River Protection Solutions LLC, Richland, Washington.

RPP-RPT-38104, 2008, Surface Geophysical Exploration of TX-TY Farms at the Hanford Site: Results of Background Characterization with Ground Penetrating Radar, Revision 0, CH2M HILL Hanford Group, Inc., Richland, Washington, Richland, Washington.

RPP-SPEC-38937, 2008, TY Farm Interim Surface Barrier Subsystem Specification, Rev. 0, Washington River Protection Solutions LLC, Richland, Washington. 